\title{
Renderings of a Queer Future: The Intersection of Impressionist Cinema and Cubist Architecture
}

\author{
Hannah Goldman \\ MARH 2017 \\ University of Virginia - School of Architecture \\ Department of Architectural History
}

April 17, 2017

Committee: Sheila Crane, Jessica Sewell, Alison Levine 


\section{Abstract}

The work of architect and set designer Robert Mallet-Stevens (French, 18861945) has long been occupied footnotes and passing mentions in the history of modern architecture. There have been many attempts to reclaim Mallet-Stevens' "rightful" place in the canon. My thesis disrupts this narrative in two parts.

The first part traces the queering of Mallet-Stevens' legacy through his collaborative process and connections to the world of fashion through his work with couturiers and cinema. These connections denigrated Mallet-Stevens in the eyes of critics like Siegfried Giedion, who deemed Mallet-Stevens' work to be morally empty, more akin to fashion than truly "Modern" architecture. This reading has shaped the discussion of Mallet-Stevens ever since. In my thesis, I argue that a queer theory reading of Mallet-Stevens' early work and his legacy find that he was radical for the very reasons that Giedion deemed him to be bankrupt.

The second half explores the film L'Inhumaine (1924) and Mallet-Stevens' first work, the Villa Noailles (1924-33) in relation to one another, linked thematically and programmatically through queer theory. Both of these works construct futuristic worlds, where the occupants pursue their passions without the constraints of heteronormativity. We can also explore the relationship of cinematic and real space through the filming of these two works. 


\section{Acknowledgements}

I would like to thank a few people for their support in the execution of my master's thesis. First of all, I would like to thank my stellar committee: Professors Sheila Crane, Jessica Sewell, and Alison Levine. I find you all so inspiring, and it has been the experience of a lifetime to get to work under your guidance. Professor Crane, thank you for all of the support you have given me as my Committee Chair. To Professor Sewell, thank you for your endless patience and guidance regarding the struggles of Graduate school. Professor Levine, I know you came into this committee on the later end, but you took this unknown territory head-on. Being able to work with an outside department is a rare honor, and I hope this work reveals how much I am glad to have your expertise in the field of French Interwar Cinema and culture. Meeting with you in January 2017 at the Colonnade Club was a big ego boost, in a time when I needed one.

I would also like to thank the Architecture School Travel Fellowships. Because of this considerable investment in my research, I was able to visit the Villa Noailles in Hyères, France, as well as the Rue Mallet-Stevens, Musée Arts Decoratif, Cité de l'Architecture, and the Centre Pompidou. Because architecture is inherently a phenomenological experience, the chance to move through these buildings in their own context was an irreplaceable component to this thesis.

Finally, I would like to thank my parents, Heather and Barry, siblings, Miriam, Noah, Seth, and partner, Austin, for your continuing emotional and general support in my studies and work on my thesis. I know you all are working toward your own goals, but I want to let you know that I understand and appreciate all of your efforts to be supportive when I have been focusing on my own pursuits. 
Table of Contents

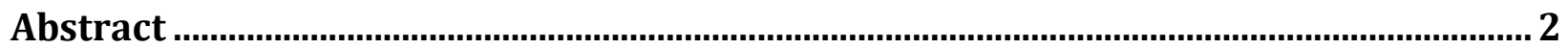

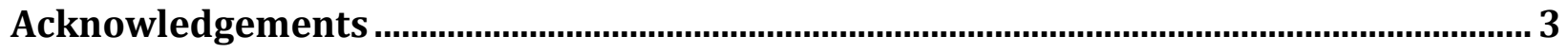

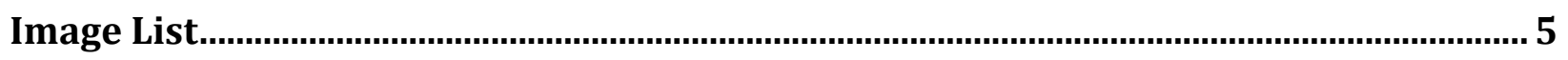

Introduction

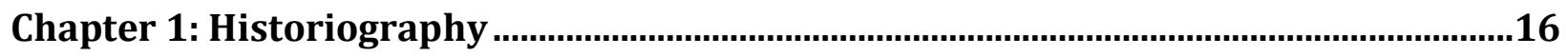

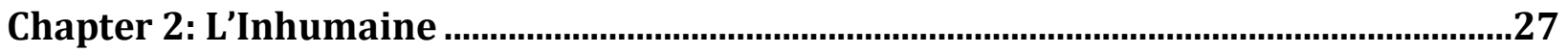

Chapter 3: Villa Noailles ...........................................................................................

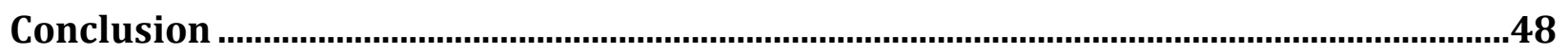

State of the Villa Noailles......................................................................................................48

State of $L^{\prime}$ Inhumaine ..................................................................................................................49

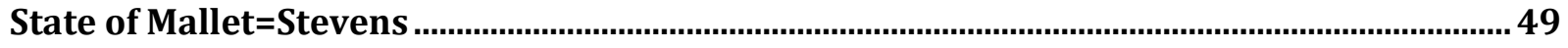

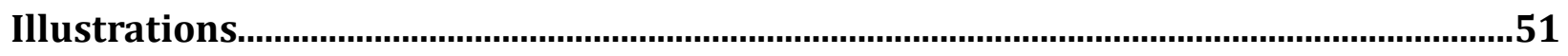

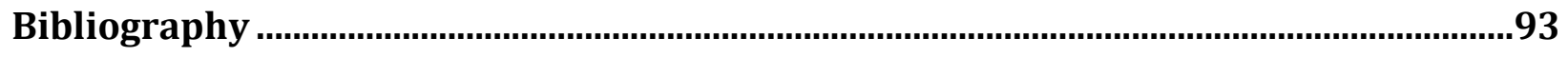




\section{Table of Images}

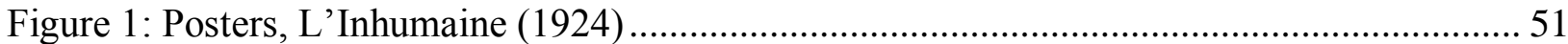

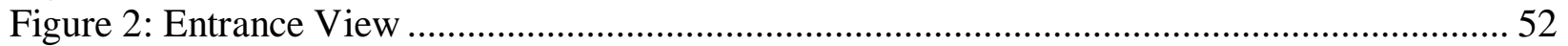

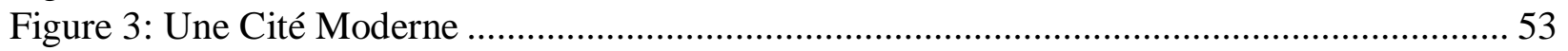

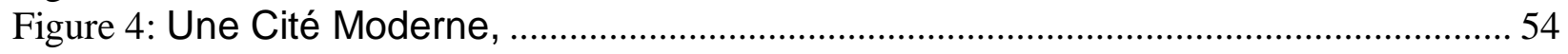

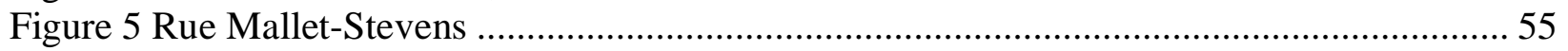

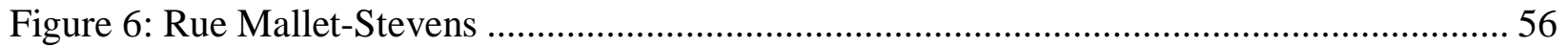

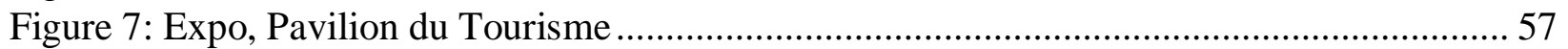

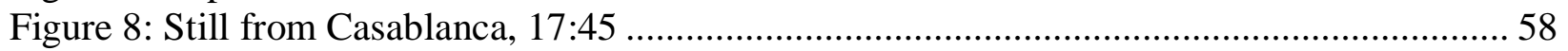

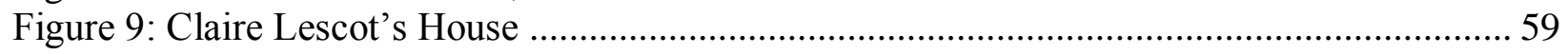

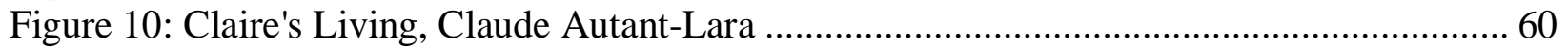

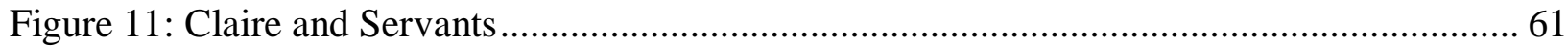

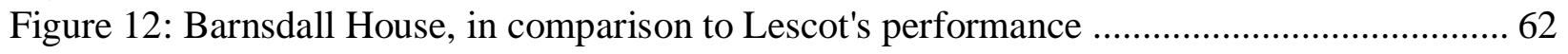

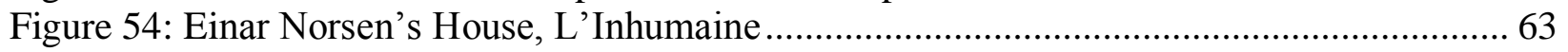

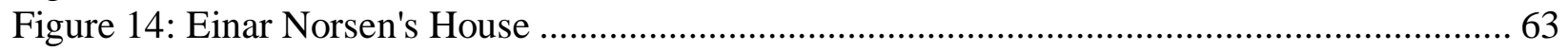

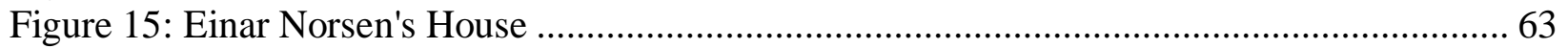

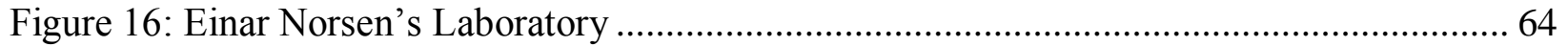

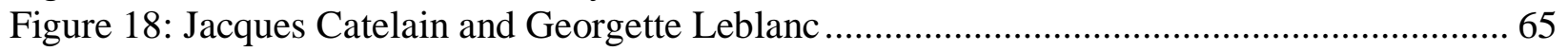

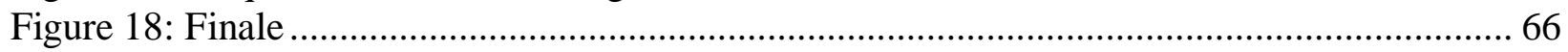

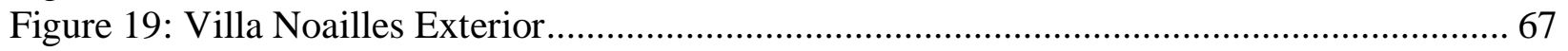

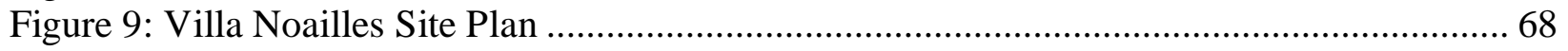

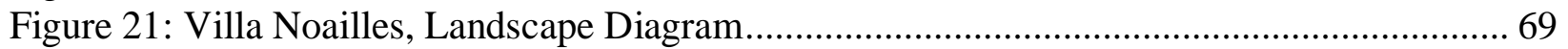

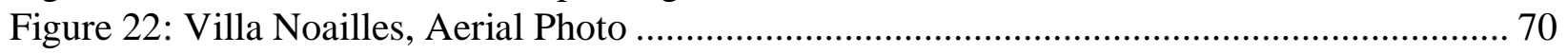

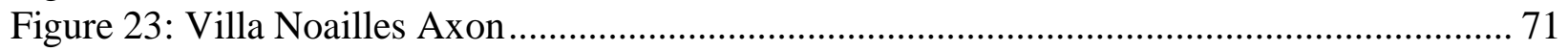

Figure 24: Villa Noailles North Façade ...................................................................... 72

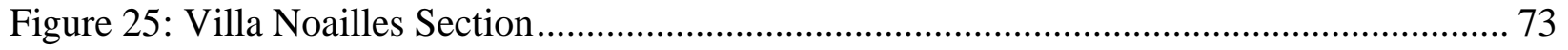

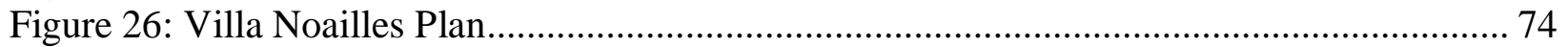

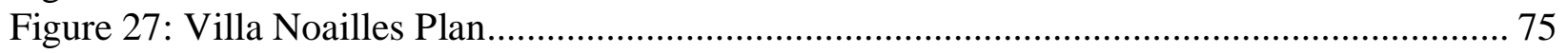

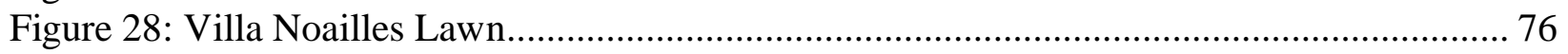

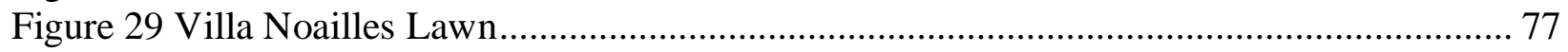

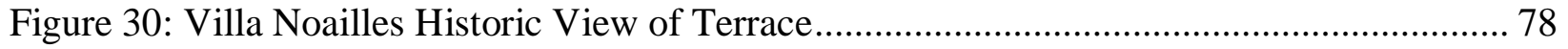

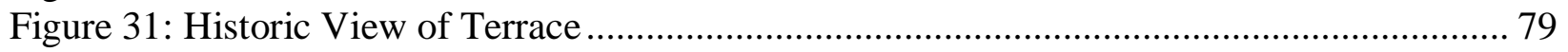

Figure 32: Villa Noailles Wall Cut out ............................................................................. 80

Figure 33: Parc St Bernard ............................................................................................... 81

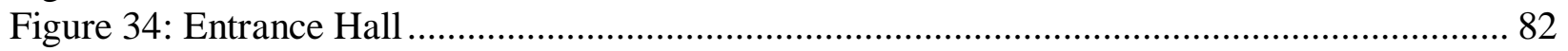

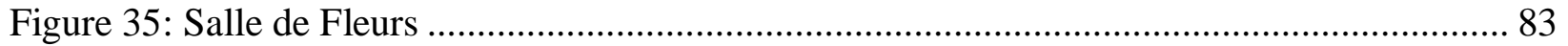

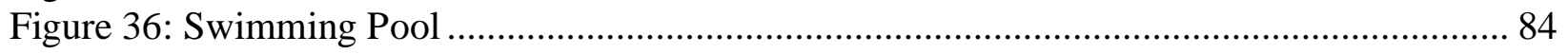

Figure 37: Guevrekian Cubist Garden, View towards sitting rooms .................................... 85

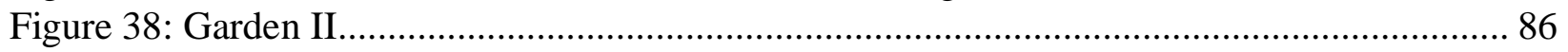

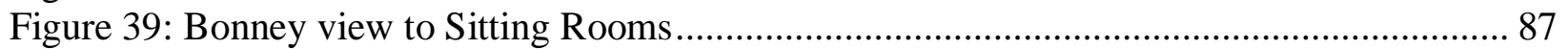

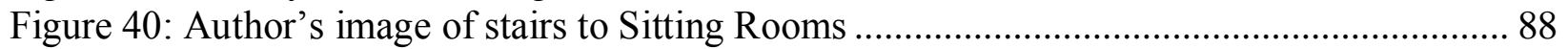

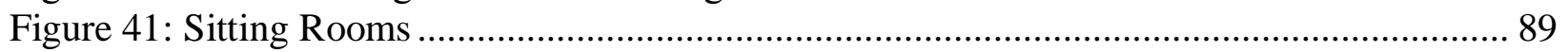

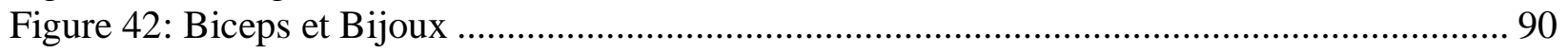

Figure 47: Stills from Les Mystères de Château du Dé..................................................... 91

Figure 44: Les Mystères de Château du Dé.......................................................................... 92 


\section{Introduction}

Robert Mallet-Stevens and his Fashionable, Inconceivable Architecture

Films are a powerful medium for providing a space for the otherwise unbelievable or inconceivable. Viewers of Blade Runner enter into a convincing dystopian version of Los Angeles. In Wes Anderson's twee The Grand Budapest Hotel, the story of how an author came to be told the story of how Zero Mustafa came into the ownership of the Grand Budapest Hotel is centered around the ages of a once-great building, now in decline. In Mon Oncle, a boy and his uncle connect around the simple joys of the old city and find humor in the ridiculousness of the lengths to which modern design forces people to change their behaviors. These films use their sets as a powerful visual storytelling tools and leave impressions on the viewers long after the credits roll. As Stanley Cavell wrote in his book, The World Viewed: Reflections on the Ontology of Film,

The world of a moving picture is screened. The screen is not a support, not like a canvas; there is nothing to support, that way. It holds a projection, as light as light. A screen is a barrier. What does the silver screen screen? It screens me from the world it holds - that is, makes me invisible. And it screens that world from me. That the projected world does not exist (now) is its only difference from reality. ${ }^{1}$

I use this quote because it accesses how real and absorbing the screen can be, and shows how film mediates the built environment. What is the nature of the relationship between the world of the screen and the world around us?

Visual media like illustration, photography, and cinema can shape, inspire, or create new spatial forms. Mallet-Stevens' early work between 1922-1924 can show the processes his work

\footnotetext{
${ }^{1}$ Stanley Cavell, The World Viewed: Reflections on the Ontology of Film (Cambridge: Harvard University Press, 1979). 24-25.
} 
undergoes from the transformation of illustrated media in Une Cité Moderne (1922), to the architectural models and set design for L'Inhumaine (1924), and finally into his first built work on the Villa Noailles in Hyères (1924-33)². But I found that there were thematic similarities between L'Inhumaine and the Villa Noailles that spoke to a camera-conscious architecture that was designed for queer occupation.

My research revealed a historiographic aspect to Mallet-Stevens' legacy that needed to be addressed before I could address more theoretical questions. Mallet-Stevens' aesthetic style and narrative were not in keeping with the Interwar critical rubric of the "modern architect" (see Becherer and Hornbeck). Mallet-Stevens was similar enough to Le Corbusier to invite comparison. However, critics like Siegfried Giedion found Mallet-Stevens lacking due to his aesthetic of "monumentality" and his collaborative spirit throughout his career. Because of this, Mallet-Stevens died a peripheral figure in 1945, without any representation in CIAM or canondefining books like Space Time and Architecture ${ }^{3}$, or Hitchcock and Johnson's International Style, three crucial modes of promotion in the Interwar architectural landscape. ${ }^{4}$ Some criticisms levelled at Mallet-Stevens during his lifetime echo in the present. ${ }^{5}$ For example, in a passing reference to Mallet-Stevens' work in Camera Constructs, Andrew Higgott contextualizes a quote from Robertson and Yerbury about the new types of people commissioning architecture with the

\footnotetext{
${ }^{2}$ Marcel L'Herbier, L'Inhumaine (The Inhuman Woman) (Lobster Films), accessed April 30, 2017, http://virginia.kanopystreaming.com.proxy.its.virginia.edu/video/linhumaine.

${ }^{3}$ S Giedion, Space, Time and Architecture: The Growth of a New Tradition (Cambridge: Harvard University Press, 1947).

${ }^{4}$ Henry-Russell Hitchcock and Philip Johnson, The International Style (New York: W.W. Norton, 1997).

5 Andrew Higgott and Timothy Wray, eds., "Frank Yerbury and the Representation of the New," in Camera Constructs: Photography, Architecture and the Modern City (Burlington: Ashgate Pub. Co, 2012), 23-33, http://search.lib.virginia.edu/catalog/u5723275.
} 
"effect of strangeness. ${ }^{6}$ Higgott says, "the contemporary French architect Mallet-Stevens provided a more acceptable version of radical work; his buildings incorporated angular decoration, and lacked the social and architectural theory which informed the production of Le Corbusier." ${ }^{7}$ What prompted this sort of pervasive narrative? Admittedly, Mallet-Stevens' work functions in a wholly different way to Le Corbusier's. It operates on different scales towards different goals from different artistic prompts and charges. It is unproductive to compare the two in such broad terms. This accusation that Mallet-Stevens lacked substantive theory behind his work is similar to the Giedieon's linking of Mallet-Stevens to academicism and fashion. Using Mary McLeod's chapter, "Undressing Architecture" from Architecture, In Fashion, we can see the ways in which an alignment between these two media would undermine the masculine architectural credibility of Mallet-Stevens. Beatriz Colomina's work in Privacy and Publicity, Colomina explicates how Adolph Loos' architectural criticisms denigrated any modern architecture that might be considered fashionable. ${ }^{8}$ Colomina writes, “...Loos’ raid against ornament is not only gender-loaded but openly homophobic." . ' Colomina also links Loos' specific attacks to Josef Hoffmann, which appears to have echoed into the critiques of his French successor, Mallet-Stevens.

An important part of this thesis is to challenge the view that Mallet-Stevens attends to surface detail without substance. This is not in the service of restoring Mallet-Stevens to his rightful place in the canon, but to examine the reasons why Mallet-Stevens was dismissed in the first place. This would mean taking the charge that Mallet-Stevens was a "fashionable" architect

\footnotetext{
${ }^{6}$ Ibid.

${ }^{7}$ Ibid.

${ }^{8}$ Beatriz Colomina, Privacy and Publicity : Modern Architecture as Mass Media / (Cambridge, Mass. : MIT Press, c1994.), http://search.lib.virginia.edu/catalog/u2313409.

${ }^{9}$ Ibid.
} 
seriously. What are the implications of this charge, especially when we take recent scholarship on queerness in Mallet-Stevens' work into account?

Robert Mallet-Stevens' (French, 1886-1945) work and legacy has undergone several cycles of critical neglect and reclamation. My thesis aims to reframe Mallet-Stevens' early work through its relationship to the camera and its queer occupation. In order to do this, we must become acquainted with Mallet-Stevens, trace the reception of his work, and bridge the two themes of camera and occupation in order to create a new frame for understanding MalletStevens' work. The connections aim simultaneously to link the disparate fields of film studies and architectural history.

Robert Mallet-Stevens, born 1886 in Paris, to Maurice Mallet, studied architecture at the École Spéciale d'Architecture. ${ }^{10}$ He was the son of art dealers, and the nephew of Adolphe Stoclet, a connection that allowed him to work with the architect Josef Hoffmann during the construction of the financier's Brussels home, known as the Palais Stoclet. ${ }^{11}$ Mallet-Stevens published articles for the Belgian magazines Le Home and Tekhné starting in 1911.12 His publications included the illustrations, originally created in 1917, for what would become his 1922 album, Une Cité Moderne. ${ }^{13}$ These illustrations show a strong influence of the Viennese Secession and the Futurist Antonio Sant'Elia's 1914 work Citta Nuova. ${ }^{14}$ Une Cité Moderne, as Mallet-Stevens presented it, was a visually cohesive urban kit of parts. He depicts his individual buildings, like train stations, cinemas, garages, and more as variations on the theme of the modern city that reimagines even traditional building types like churches (

) and government buildings. ${ }^{15}$ There is no accompanying plan of this imagined city, in fact, there is virtually no urban aspect to this city. Each building is presented alone in the drawing's frame, with little context indicated. Each is presented as if it were a kind of pastoral city, situated on urban carte blanche (Figure 4). ${ }^{16}$ There are streets and landscapes indicated, but

${ }^{10}$ Dominique Deshoulières and Hubert Jeanneau, "The Demands of Architecture," in Rob Mallet-Stevens: Architecte (Bruxelles: Archives d’Architecture Moderne, 1982), 35-61.

${ }^{11}$ Ibid. 36.

12 Ibid. 38.

${ }^{13}$ Robert Mallet-Stevens, Une Cité Moderne: Dessins de Rob Mallet-Stevens. (Paris: MilleFeuille, 1987). 3.

${ }^{14}$ Ibid. 7.

15 Ibid.

${ }^{16}$ Deshoulières and Jeanneau, "The Demands of Architecture." 39. 
the architect does not provide spatial cohesion as part of his imagined city. Because MalletStevens did not start constructing larger cinematic and architectural projects until 1923-24, we can see Une Cité Moderne as a preview of Mallet-Stevens' aesthetic inclinations and his "visual demonstration of his own idea of the city." 17 Despite the drawings' "disconcerting naivety," it does not appear that the book resulted in any immediate clients. ${ }^{18}$ The book serves merely as a research exercise for Mallet-Stevens. Later, however, we can see traces of the visual and programmatic elements explored in Une Cité Moderne in Mallet-Stevens' built work. For instance, we see an emphasis on monumentality, a variety of ornament on cubic massing, and an admiration for the tower form.

We cannot understand Mallet-Stevens' work without accounting for the impact of his networks and collaborations. For instance, Une Cité Moderne was published by Frantz Jourdain, father of painter Francis Jourdain, one of the founding members of the Salon d'Automne. ${ }^{19}$ It was the friendship between the Jourdains and Mallet-Stevens that provided the opportunity for the latter to present at the 1912 Salon d'Automne in the first place. Richard Becherer, in his essay, "Past Remembering: Robert Mallet-Stevens's Architecture of Duration," speculates that "a fair share of Robert Mallet- Stevens's early commissions can be traced to the élite social milieu within which he was raised." 20 According to Jeanneau and Deshoulières, it was the Salon d'Automne that initially encouraged Mallet-Stevens' professional contact and collaboration with painters and interior designers. ${ }^{21}$ The relationships between Mallet-Stevens, Francis Jourdain,

\footnotetext{
${ }^{17}$ Ibid.

18 Ibid.

${ }^{19}$ Ibid. 38.

${ }^{20}$ Richard Becherer, "Past Remembering: Robert Mallet-Stevens's Architecture of Duration," Assemblage, no. 31 (December 1996): 39.

${ }^{21}$ Deshoulières and Jeanneau, "The Demands of Architecture." 38.
} 
and Pierre Chareau formed at this time would lay the groundwork for creation of the Union des Artistes Modernes (UAM) in 1929.

Mallet-Stevens was a chartering member of UAM, which aimed to break with the prevailing, more conservative group, Societé des Artistes Décorateurs (SAD). ${ }^{22}$ UAM founding members included Le Corbusier, Charlotte Perriand, and Pierre Chareau. The designers associated with UAM broke with SAD to create works that would be simultaneously avant-garde and affordable. This was to contrast with the inaccessible luxuries exhibited by SAD in the 1925 Paris Exposition des Arts Décoratifs et Industriels. The group disbanded following MalletStevens' death in $1945 .^{23}$

It was through the networks created by the French exhibition circuit that Mallet-Stevens was recommended to Charles and Marie-Laure de Noailles. In a 1977 description of the Villa Noailles, Charles de Noailles recalls that the couple "asked the opinion of Mr. Metman, director of the Musée des Arts Décoratifs and an old friend... He did not hesitate, saying that when the museum had given exhibitions of modern architecture, the only one who seemed to him to have any taste or imagination was Mallet-Stevens." 24 The Villa Noailles is a winter home commissioned by the de Noailles located in the hills of Hyères, a small town on the Côte d'Azur that slowly morphed into a private resort for the de Noailles to host artists and pursue their passions. Many of the people who worked on the Villa Noailles made up the initial members of UAM, including Chareau and Jourdain, as well as Eileen Gray, Charlotte Perriand, and Louis

\footnotetext{
22 “Union Des Artistes Modernes - Oxford Reference," accessed April 29, 2017, http://www.oxfordreference.com/view/10.1093/oi/authority.20110803110717894.

${ }^{23}$ Danilo Udovički-Selb, "Reinventing Paris," Journal of the Society of Architectural Historians 74, no. 2 (June 1, 2015): 179-200, doi:10.1525/jsah.2015.74.2.179.

${ }^{24}$ Dominique Deshoulières and Hubert Jeanneau, eds., "Description by the Viscount de Noailles of the Construction of His Villa in Hyères - 1977," in Rob Mallet-Stevens: Architecte, trans. Susan Day (Bruxelles: Archives d’Architecture Moderne, 1982), 387-88.
} 
Barrilet. It is likely that many of the early members of UAM also exhibited at the Salon d'Automne prior to 1929, but thereafter they were united under their director: Robert MalletStevens. The Noailles were extremely wealthy patrons who funded the expansive project of filling their villa with bespoke objects and creative people. Because of the scope of the project, we see that some of the designers were hired at the behest of the patrons, like Theo van Doesburg or Gabriel Guevrekian, and some were recommended to the project by Mallet-Stevens, like Djo Bourgeois, who worked with Mallet-Stevens on Marcel L'Herbier's 1924 film

\section{L'Inhumaine.}

The film world, especially the world of the silent film director Marcel L'Herbier, represents yet another network of artisans and personalities connected to Mallet-Stevens' early work. L'Inhumaine is a silent film from 1924, directed by Marcel L'Herbier and produced by Georgette Leblanc. Mallet-Stevens was one of four set designers working on the film, and his primary role was the creation of the exterior views of the two main character's houses. MalletStevens designed sets throughout his career for a number of directors, but $L$ 'Inhumaine is his best-known work. The film was created with the 1925 Art Deco Exhibition in mind as a way to showcase the work of France's leading designers in a Wagnerian Gesamtkunstwerk. The positive reviews focused on the success of the film's visual language and composition, while downplaying the importance of the plot. Adolf Loos, who helped to organize a screening of the film in Paris, noted in his review of the film published in Die Freie Presse that, "The production of the last images of L'Inhumaine surpasses the imaginable. After watching it, one feels as though they had experienced the birth of a new art." ${ }^{25}$ Loos' review highlights the way in which

25 Adolf Loos, “'L'Inhumaine' Histoire Féerique,” trans. H. Goldman and Google Translator, Neue Freie Presse, July 29, 1924, http://anno.onb.ac.at/cgicontent/anno?aid=nfp\&datum $=19240729 \&$ zoom $=33$. S9. 
the film uses new art forms like modern architecture and jazz music to create "an abundance of new movie ideals". ${ }^{26}$ Loos' review reveals a way in which existing avant garde styles, when properly blended in cinema, can generate a new art form. Many accounts and academic readings of this film emphasize the elements of the film's aesthetic experimentation and the nature of the relationship between the arts and science. Maureen Shanahan in her essay "Indeterminate and Inhuman: Georgette Leblanc in L'Inhumaine" argues that these readings ignore the queer undertones of the film's actors, plot, and cultural references. ${ }^{27} \mathrm{I}$ found benefits to both readings. On the one hand, there is a discussion of the nature of technology and the human condition in the Interwar period. In the traditional reading, the "inhuman" in L'Inhumaine relates to technology and its phenomenal powers. On the other hand, a queer reading of the film's plot creates a thematic link between L'Inhumaine and the Villa Noailles. Mallet-Stevens designed the houses of the main characters and the Noailles as a stage for pursuing passions, rather than pursuing heteronormative domestic life. In this way, we see that these domestic sets are representations of the characters. These representations are, if anything, more expressive and complete than the films' characterization of the main characters. This reading's semantic iteration of "inhuman" relates more to the "female" part of the title, L'Inhumaine. A woman who does not desire suitors, is career driven, and feigns heartlessness is not an ordinary woman. The supposed love story is not motivated by a sexual desire, but an asexual, humanitarian one, as the main characters' greatest desires are to bring music and joy to the whole world through technology.

Rob. Mallet-Stevens' work as a film and set designer allowed experimental design ideas to filter through his concurrent architectural practices. His work in the French film industry

\footnotetext{
${ }^{26}$ Ibid.

${ }^{27}$ Maureen G. Shanahan, 'Indeterminate and Inhuman: Georgette Leblanc in 'L'Inhumaine' (1924)," Cinema Journal 43, no. 4 (2004): 53-75.
} 
created non-traditional networks of artists and designers with whom he would not have normally interacted, such as his professional relationship with the couturier Paul Poiret, who designed costumes for L'Herbier's films. This desire to experiment in architecture brought the commission for the Villa Noailles, which was initially a winter house that metastasized into the small resort it became. Because of Mallet-Stevens' film work, the surrealist Man Ray saw the Villa Noailles is "a natural set" for his 1929 short film, Les Mystères de Château du Dé. ${ }^{28}$ Would Man Ray have assumed the house was predisposed to the camera's eye without this knowledge? The short answer is yes. The long answer addresses the ways in which Mallet-Steven's early career, around 1924, during his work on L'Inhumaine and the Villa Noailles, shows the jump from the world of the screen to the built, plastic world. At the same time, this thesis speaks to the latent queer themes that link the homes of L'Inhumaine to the Villa Noailles. These are queer spaces, that are not merely queer because of their occupants' sexual identities, but because of their partis. These are aesthetically and programmatically radical spaces that reinforce and support lifestyles that eschew tradition and normative lifestyles. Queer spaces in Mallet-Stevens' oeuvre and his connections to the fashion world invite a new reading of his denigration by critics like Siegfried Giedion, who maligned Mallet-Stevens' work as merely fashionable, rather than substantive and serious. Because films create a space where the unimaginable is rendered in real space, we can see the ways in which queer patronage might bring filmic architecture into the embodied world. The "unimaginable" aspect, especially in architecture is often framed in terms

${ }^{28}$ Jean-François Pinchon, ed., Rob. Mallet-Stevens: Architecture, Furniture, Interior Design: A Collective Work Presented by the Délégation À l'Action Artistique de La Ville de Paris on the Occasion of the Centenary of the Birth of Mallet-Stevens, 1st MIT Press ed (Cambridge, Mass: MIT Press, 1990), http://search.lib.virginia.edu/catalog/u1843269. 34. 
of science fiction, but in L'Inhumaine and the Villa Noailles, Mallet-Stevens' architecture sets the stage for and renders an already real world of queer spaces of passion and leisure.

My thesis aims to show the ways in which a joint reading of Mallet-Stevens' set design and early architecture can enrich an understanding of these spaces, given the ways in which these two works are similar. The sets in L'Inhumaine and the Villa Noailles become representations of their occupants, and are spaces where gender and sexuality are performed without heteronormative limitations. 


\section{Chapter 1: Historiography}

Following Mallet-Stevens' death in 1945, the world was not yet ready to understand the legacy of a peripheral figure in architecture, and a groundbreaking figure in early set design. In the 1970s, there was a resurgence of interest in the Interwar period, nearly fifty years after the height of Impressionist Cinema. Barsacq's 1970 book, Le décor de film, which was translated into English in 1978, took a major first step in bringing serious attention to set design as a creative endeavor with its own history. ${ }^{1}$ Art historian Standish Lawder's book Cubist Cinema was one of the earliest books in English on early French cinema. ${ }^{2}$ Around this time, David Bordwell, now an author of film studies textbooks, submitted his dissertation French Impressionist Cinema. In it, he attempts to define the unified movement of Impressionist film through their similarities they possess, including subjective camerawork and editing as a storytelling device. Neither Lawder nor Bordwell touched the subject architecture. In fact, Lawder pointed out that Henry-Russell Hitchcock misidentified Mallet-Stevens' nationality by saying he was Belgian, but then goes on to say that Mallet-Stevens would be the "most important French architect of the twenties" as long as we categorized Le Corbusier as Swiss. ${ }^{3}$ His discussion of architecture is limited to contemporary buildings. In fairness to Lawder, his description of L'Inhumaine was very evocative, and included accounts of the film's production. While these film studies books ignore the significance of the architecture, they were also attempting to define stylistic genres. Lawder's Cubist cinema is defined as the synthesis of a Cubist way of seeing and the new cinematic art form. In comparison to Bordwell's thorough

\footnotetext{
${ }^{1}$ Léon Barsacq, Le décor de film. ([Paris: Seghers, 1970).

${ }^{2}$ Standish D. Lawder, The Cubist Cinema / (New York : New York University Press, 1975), http://search.lib.virginia.edu/catalog/u472051.

${ }^{3}$ Ibid. 254.
} 
analysis of the cinematic aspects of the film, Lawder's training as an art historian shines through, making his claims based more on aesthetics, visual culture, and artistic creation.

Hubert Jeanneau and Dominique Deshoulières edited and published the foundational MalletStevens monograph, Rob Mallet-Stevens, Architecte. ${ }^{4}$ It was translated into English in 1982. This book was a school project for Deshoulières and Jeanneau while they were still enrolled at the École des Beaux-Arts in Paris, completed with the help of archivists, curators, and people who knew Mallet-Stevens. Their goal was to collect available information on Mallet-Stevens; biographical, professional, contextual, visual and archival material is presented within the book's nearly four hundred pages. This speaks to the availability of information about Mallet-Stevens and the dearth of collected work about him up to that point. The book features essays by Musée Arts décoratifs curator Yvonne Breunhammer, who wrote an essay about Mallet-Stevens' work as an interior designer. An author named Michel Louis, possibly a schoolmate of Jeanneau and Deshoulières, wrote an essay about Mallet-Stevens' film work. The editors contributed a chapter on Mallet-Stevens' biography, as well as providing a wide variety of archival materials, including published writings by Mallet-Stevens as well as drawings and images of projects. The book's overall adherence to chronology and biography suggest that the purpose of the book was to establish a timeline of Mallet-Stevens' life and work in order to lay the groundwork for his posthumous inclusion in the modernist canon.

Richard Becherer's 1981 essay in Journal of the Society of Architectural Historians entitled, "Monumentality and the Rue Mallet-Stevens,"5 discussed the critical reception of the

\footnotetext{
${ }^{4}$ Hubert Jeanneau, ed., Rob Mallet-Stevens, Architecte / (Bruxelles : Archives d'architecture moderne, 1980), http://search.lib.virginia.edu/catalog/u208443.

${ }^{5}$ Richard Becherer, "Monumentality and the Rue Mallet-Stevens," Society of Architectural Historians Journal 40, no. 1 (March 1981): 44-55.
} 
1927 Parisian development on the Rue Mallet-Stevens (Figure 5, Figure 6) by Siegfried Giedion, who dismissed the development as being too "monumental." ${ }^{67}$ Becherer goes on to explain how the criticism of "monumentality" was a subtle jab at Mallet-Stevens for being too Academic or ornamental. This essay is one of the earliest critical approaches to Mallet-Stevens. Rather than simply laying out the chronologically of Mallet-Stevens' works, Becherer works through the lens of Mallet-Stevens and “monumentality”. Becherer's framing of Mallet-Stevens' conception of monumentality relates to how urban built environment can be more cohesive when built with the same set of aesthetic and societal mechanisms. We can see the aesthetic side of Mallet-Stevens' monumentality in the proportions and cohesiveness of his architecture groupings, like Une Cité Moderne and the Rue Mallet-Stevens. ${ }^{8}$ The essay focuses on context and reframing of concepts like monumentality to find new ways of reading Mallet-Stevens' of the Rue Mallet-Stevens, and Mallet-Stevens' work more broadly. Becherer touches on the link between "fashion" and Giedion's conception of "monumentality," explaining that "Fashion smacks of transiency... For Giedion, the hallmarks of fashionable architecture include luxury and purely cerebral, esthetic interests, all of which remove architecture from the realm of the realistic."9 This is as far as Becherer's analysis goes to link Mallet-Stevens to “fashionable architecture.” Becherer rejects Giedion's indictment of the Rue Mallet-Stevens by examining the architect in his own words. Rather than close the discussion at this critically damning work, Becherer uses negative criticism

${ }^{6}$ Richard Becherer, a constant presence in Mallet-Stevens academic discussions wrote his 1977 dissertation, Robert Mallet-Stevens: A Forgotten Precursor of Modern Architecture, which I have not been able to access at the time of writing. ${ }^{6}$ Given the title and Becherer's other work on Mallet-Stevens from 1981 through 2000, I assume it was in pursuit of a reclamation of Mallet-Stevens' legacy.

${ }^{7}$ Richard John Becherer, Robert Mallet-Stevens: A Forgotten Precursor of Modern Architecture (Cornell University, May, 1977).

${ }^{8}$ Ibid.

${ }^{9}$ Ibid. 45. 
to access a new reading of Mallet-Stevens' work. It prefigures the 1990s wave of feminist art and architectural history that we will consider shortly.

Despite truncating what could have been a focus on fashion and Mallet-Stevens, Becherer has an excellent discussion on Mallet-Stevens' conception of cinema and the statements required of his modern architecture. Becherer writes that, "Mallet-Stevens emphasized the importance of film to modern culture, for unlike theater, it was immensely popular. This was due largely to film's ability to convincingly portray the unreal..."10. This is an early example of the ways in which the relationship between L'Inhumaine and Mallet-Stevens' built architecture on the Rue Mallet-Stevens can be connected and understood together. L'Inhumaine and its ultramodern world is "projecting an optimistic view of the world as it could be, a society capable of anything, even immortality, provided science were allowed to run its course unimpeded." ${ }^{11}$ This analysis is more nuanced than the earlier Deshoulières and Jeanneau iterations, and it bridges the divide between the built world and the screened world, if only for a few paragraphs.

Discourses surrounding Mallet-Stevens were not directly impacted by the feminist wave of the 1990s, but many of the approaches and theory originating from this fruitful period were integral to my analysis, especially. Alice T. Friedman's 1998 book Women and the Making of the Modern House ${ }^{12}$ Beatriz Colomina's Sexuality and Space and Privacy and Publicity; ${ }^{13}$ Caroline Constant's essay “E. 1027: The Nonheroic Modernism of Eileen Gray;” ${ }^{14}$ and her edited volume

\footnotetext{
${ }^{10}$ Ibid. 53.

${ }^{11}$ Ibid.

12 Alice T. Friedman, Women and the Making of the Modern House : A Social and Architectural History /(New York: Harry N. Abrams, 1998), http://search.lib.virginia.edu/catalog/u2795321. ${ }^{13}$ Colomina, Privacy and Publicity.

${ }^{14}$ Caroline Constant, "E. 1027 The Nonheroic Modernism of Eileen Gray,” Journal of the Society of Architectural Historians 53, no. 3 (1994): 265-79, doi:10.2307/990937.
} 
on Eileen Gray, entitled Eileen Gray: An Architecture for All Senses. ${ }^{15}$ According to Mary

McLeod in 2004, in Harvard Design Journal that the early 1990s saw an explosion in feminist writing, with authors engaged in heated discourse, committed to reclaiming forgotten women artists, and succeeding in taking the "reputations of architecture's male heroes ... down a notch or two," as well as exposing the architectural profession's inequalities. ${ }^{16}$ These texts operate in very different ways.

Friedman's book uses the lens of female and queer (often both) patronage to show how the innovations made by the great modern architects were actually attributable to the experimental patrons, not the experimental architects who have taken credit for them. Friedman's chapter on the Rietveld Schröder house has changed our understanding of the building by including its patron, co-designer, and owner, Truss Schröder, rather than attributing all of the innovation of moving walls and flexible spaces solely to Gerrit Rietveld. ${ }^{17}$ My engagement with Friedman's book in this thesis will be limited to her chapter on the Hollyhock House, built by Frank Lloyd Wright for Aline Barnsdall between 1919-1921. ${ }^{18}$ This chapter focuses on conflicts between the architects and patrons relationship, especially designs in the service of a radical queer woman. There are direct similarities to the way in which Frank Lloyd Wright treated Aline Barnsdall and the way the production team for L'Inhumaine treated their executive producer

${ }^{15}$ Eileen Gray, Caroline Constant, and Wilfried Wang, Eileen Gray: An Architecture for All Senses (Berlin; Tübingen; Frankfurt am Main; Harvard: Wasmuth ; Deutsches ArchitekturMuseum ; Harvard University Press Graduate School of Design, 1996).

${ }_{16}$ Mary McLeod, "Perriand: Reflections on Feminism and Modern Architecture," Harvard Design Magazine No. 20, no. Stocktaking 2004: Nine Questions about the Present and Future of Design (2004), http://www.harvarddesignmagazine.org/issues/20/perriand-reflections-onfeminism-and-modern-architecture.

${ }^{17}$ Friedman, Women and the Making of the Modern House. ${ }^{18}$ Ibid. 
Georgette Leblanc, as well as the programmatic similarities between the Barnsdall House and Claire Lescot's living space in the film.

Beatriz Colomina's edited volume Sexuality and Space and her book Privacy and Publicity both examine sexuality as it relates to architecture. In the preface to Sexuality and Space, Colomina writes, "It is not a question of looking at how sexuality acts itself out in space, but rather to ask: How is the question of space already inscribed in the question of sexuality?"19 She goes on to say that we must change our thinking about architecture to think of it as a type of media, "not only because architecture is made available to us through these media [drawings, photographs, film, etc.] but because the built object is itself a system of representation." 20 Colomina's underlying assumption in all of her work is that architecture is a type of media, or a system of representation. We can see this through-line in the essays she selected for Sexuality and Space, where there are at least two papers that use film and television as their preferred media to bridge the space between the fields of sexuality and architectural space. In her own work in Privacy and Publicity, Colomina's chapter "Interior," was both the most applicable and best known portion of this book. ${ }^{21}$ Colomina sets up a discussion of how interiority operates in homes designed by Adolf Loos and Le Corbusier. ${ }^{22}$ Colomina's concept of interiority relates to theatricality and sexuality. She argues that the nature of a domestic interior space that is reminiscent of a theater box, is to subvert the safety provided by a public theater box, and architects like Loos use this spatial design to control the behavior of their female occupants. This

\footnotetext{
${ }^{19}$ Beatriz Colomina and Jennifer Bloomer, eds., Sexuality \& Space, Princeton Papers on Architecture 1 (New York, N.Y: Princeton Architectural Press, 1992), http://search.lib.virginia.edu/catalog/u1964473.

${ }^{20}$ Ibid.

${ }^{21}$ McLeod, "Perriand: Reflections on Feminism and Modern Architecture."

${ }^{22}$ Colomina, Privacy and Publicity.
} 
male gaze of female "privileged space" inside their own homes undermine the safety of a private space. The voyeurism in Loos' house, however, does operate in a different way than Le Corbusier's Villa Savoye. In the chapter "Windows," Colomina argues that where Loos implies and invites a predatory male gaze on the female body, Le Corbusier's windows and architecture frame the occupants, transforming them into subjects of voyeurism, without emphasizing femalealigned interiority. ${ }^{23}$ Colomina also notes that Loos' denigration of Hoffmann's and the "Vienna Secession architects as being 'dilettanti,' 'fops,' and 'suburban dandies' who buy their 'pre-tied ties in the woman's fashion displays.' The question of modernity cannot be separated from that of gender and sexuality." 24 Colomina's understanding of the homophobia in Loos' attitude toward Hoffmann informed my reading of Giedion's reading of Mallet-Stevens' work, based on the similarities between the two criticisms.

Colomina's interest in the spatial dynamics of seeing and view-framing also helped to inform my understanding of the ways in which Le Corbusier employs windows and frames to create spaces with film or photography in mind, and how that operation might be different for a man who was designing film sets concurrently with his spaces at the Villa Noailles.

Caroline Constant's work on Eileen Gray, particularly her essay “E. 1027: The Unheroic Modernism of Eileen Gray" 25 reveals a way in which a marginalized figure can be rehabilitated in a careful way, without capitulating to overly biographical sources. Gray and Mallet-Stevens are not equivalent in their relegation, serve the dynamics of remembering and celebrating female artists has been historically problematic, especially in Gray's case. Nevertheless, approaches to Eileen Gray's seaside villa, E. 1027 provide a way of analyzing a queer space, absent the

\footnotetext{
${ }^{23}$ Ibid.

${ }^{24}$ Ibid. 38.

${ }^{25}$ Constant, "E. 1027."
} 
domestic requirements of spaces like the Villa Savoye. At the Villa Savoye, Le Corbusier puts children in the publicity images of the Villa, defining the Villa Savoye as a space for a family, despite its machine aesthetics. ${ }^{26}$ Gray and Mallet-Stevens, in this way, are creators of a similar type of architecture, but one without the constraints of a traditional family structure determining the program.

The 1990s also saw an explosion of work examining film and architecture. Anthony Vidler's 1993 essay in Assemblage, may have initiated this wave of new interest. It was a theoretical work, discussing how architecture could be experimental in films because they were not slowed down by concepts like ease of occupation and gravity. His essay was adapted for an exhibition catalogue edited by Dietrich Neumann in 1999 for an exhibition entitled, Film Architecture: Set Designs from Metropolis to Blade Runner. ${ }^{27}$ While this exhibition catalogue does provide a careful survey of the best film sets throughout history, it is image-heavy and focuses more on synthesis than analysis. In 1996, there was a conference on film and architecture called, Cinema \& Architecture: Méliès, Mallet-Stevens, Multimedia, edited by François Penz and Maureen Thomas, in which Odile Vaillant analyzed Mallet-Stevens' approaches to set design, and what the effect those approaches had on his design for the Villa Noailles. She says, "He imagined a unity between interior and exterior architecture, a relationship which would organize the continuity of the design, and to obtain it he used walls, openings and terraces." 28

\footnotetext{
${ }^{26}$ Colomina, Privacy and Publicity.

${ }^{27}$ Dietrich Neumann, Film Architecture: Set Designs from Metropolis to Blade Runner (Prestel, 1999).

${ }^{28}$ François Penz and Maureen Thomas, eds., Cinema \& Architecture: Méliès, Mallet-Stevens, Multimedia (London: British Film Institute, 1997), http://search.lib.virginia.edu/catalog/u2638581. 33.
} 
Unfortunately, the essay is all too short to get into the implications of the implications of this interior/exterior unity.

The Pompidou Centre released an exhibition catalogue for its 2005 show, Robert MalletStevens: L'oeuvre Complète that is more thorough and carefully produced than the earlier iteration of the project by Jeanneau and Deshoulières. ${ }^{29}$ It provides more of everything: images, archival work, published work, and scholarly contextual essays. But it does not give space to a nuanced feminist approach to Mallet-Stevens that has been a rich source of understanding dynamics of architectural media in the Interwar period. I read the Pompidou's inclusion of Mallet-Stevens a way for the institutional powers to posthumously induct Mallet-Stevens into the canon, rather than ask the more nuanced question of what forces were at work that caused a wellknown architect in the twenties to be subsequently ignored.

By contrast, Mallet-Stevens has greatly benefitted from 1990s feminist and queer approaches, as is evident in three essays and books that give a more nuanced reading of MalletStevens.

In Atlas of Emotion, Giuliana Bruno questions how cities can operate like montages, taking a cue from Colomina's interest in the effect of destabilization of the viewer in cubist art. ${ }^{30}$ This is especially interesting when we take into account the fact that Charles de Noailles remarked that with the synchronized clocks in every room of the Villa Noailles, it felt as if the Villa was its own small city.

Elizabeth Hornbeck's dissertation, "Visions of Modernity: The Architectural Landscape of the 1925 Exposition of Decorative Arts, Paris” examines Mallet-Stevens' work through the

${ }^{29}$ Robert Mallet-Stevens, Robert Mallet-Stevens : L'ceuvre Complète / (Paris : Centre Pompidou, 2005), http://search.lib.virginia.edu/catalog/u4296122.

${ }^{30}$ Giuliana Bruno, Atlas of Emotion: Journeys in Art, Architecture, and Film (Verso, 2002). 
concept of modernism and the future, particularly his pavilion in the 1925 Paris Expo. ${ }^{31}$ Her introduction provides a thorough explanation for her choice to focus on Mallet-Stevens' work, rather than his biography. Her final chapter also compares how Mallet-Stevens and Le Corbusier were received by contemporary critics. Her work outlining how Mallet-Stevens' work was publicized in Vogue further implicated his architecture's relationship with fashion, and how these engagement effected his career. (Figure 7) This image is taken from a 1925 issue of Vogue that published a guide to the Expo, featuring Mallet-Stevens' Pavilion du Tourisme.

Megan Meulemans' essay “Exposing the Villa Noailles: The Women Behind the Promotion of Robert Mallet-Stevens," considers the women who actively promoted MalletStevens' work during his early career. ${ }^{32}$ Meulemans focuses on Marie-Laure de Noailles and Thérèse Bonney as two integral people who supported Mallet-Stevens in his burgeoning career, but have been essentially written out of histories of Mallet-Stevens. This essay's focus on the collaborative aspects of Mallet-Stevens career, especially with independent women, spoke to the counter narrative to Modernism I saw in Mallet-Stevens work.

Maureen Shanahan's essay "Indeterminate and Inhuman”, mentioned above, offers a queer theory reading of L'Inhumaine, and gives a very convincing account of the troubles regarding Georgette Leblanc's patronage and the legacy of the film. ${ }^{33}$ This, in turn, makes the discussion of patronage and architecture relatable to Friedman's work on architectural patronage.

\footnotetext{
${ }^{31}$ Elizabeth Jean Hornbeck, "Visions of Modernity: The Architectural Landscape of the 1925 Exposition of Decorative Arts, Paris" (Ph.D., University of California, Santa Barbara, 2002), http://search.proquest.com/docview/304804620/abstract/E27CF79EDE824FB6PQ/1.

32 Megan Meulemans, "Exposing the Villa Noailles: The Women Behind the Promotion of Robert Mallet-Stevens," International Journal of the Image 1, no. 4 (December 2011): 119-39. 33 Shanahan, "Indeterminate and Inhuman."
} 
Recent work on Mallet-Stevens' work and it relationship to the body have operated in both his film and architecture. But previous scholars have failed to notice to thematic similarities of the houses of L'Inhumaine and the Villa Noailles, which is what I aim to do in this thesis. 


\section{Chapter 2: L'Inhumaine}

L'Inhumaine (1924) is a film that is accurately described as "one of the most absurd Great Movies ever made." "1 The title, translates to "The Inhumane Woman," which is not very representative of the film. The plot is so insignificant that the film's legacy is often framed around its stylistic and visual experimentation, with good reason. The plot, in short, is a front for L'Herbier and company's Art Deco gesamtkunstwerk. Claire, an established opera singer with a reputation for being "inhumane" or "cold" finds a partner in young scientist Einar Norsen, who shows her a way to broadcast her music to the world without having to leave France. Claire's spurned suitor poisons her to death with a snake, and Einar's untested science briefly brings her back to life. Ultimately, these twists and turns are dramatic ways of getting from one fantastic set to another: a geometric dining room (complete with moat and live geese), an indoor "winter garden”, a cubist laboratory, a dramatic plinth. The set design and striking unique imagery are the true legacies of this film.

In this chapter, I will examine how gender and sexuality are performed in this film. In this paper, I am using Judith Butler's conception of gender as performance. ${ }^{2}$ In the entire "romantic" drama, there is only imagined physical affection between Claire and her supposed paramour, Einar. Since the main characters' houses are both seen as iconic in French silent film and Interwar French architecture, I want to analyze those spaces and attempt to examine the ways in which they bolster their owner's characters. How does the architecture change the understanding of the film? How might it destabilize the expectations of heteronormativity in the film?

\footnotetext{
${ }^{1}$ David Melville, “Ebertfest: Roger Ebert's Film Festival: L’Inhumaine,” April 13, 2016, http://www.ebertfest.com/eighteen/linhumaine.html.

2 Judith Butler, "Performative Acts and Gender Constitution: An Essay in Phenomenology and Feminist Theory," Theatre Journal 40, no. 4 (1988): 519-31, doi:10.2307/3207893.
} 
In the set of $L$ 'Inhumaine, each fantastical room is a set in and of itself, probably unconnected to any other "room" in the film (aside from the foyer connecting to Claire's great hall.) In some films, the director and crew take great pains to make a space that is legible to the audience, an effort that aids the director in telling the story without distractions. For example, in Casablanca (1942) as we can see in Figure 8, Rick's cafe and office are constructed and filmed so that Rick can go upstairs to his office while staying in one take (this happens at around the 17:45 minute mark). This comparison is unfair to L'Inhumaine, of course, since this 1924 silent film represents the vanguard of bespoke set design. Mallet-Stevens once wrote that prior to his time, films were decorated with whatever was lying around the studio and sets, so you would see the same vintage-looking chairs and perspectival-painted canvases in every film prior to his work with L'Herbier.

L'Herbier wanted to make this film an exemplary export of France's culture to the rest of the world. So, he created a gesamtkunstwerk with the help of artists, architects, couturiers, and set designers. L'Inhumaine represents his ideal of cinema total, which was the idea of bringing in all of the arts together to make a film that was a total work of art. We can see this particularly well in Einar's Laboratory, where, in the stills, the arrangement of objects, lines, and shapes, make the room look like a late cubist work; the space is legible as a kind of painting. Cubism is known for taking three-dimensional space and compressing it into a flat surface with an assemblage of shapes to denote spatial complexity. L'Herbier and Léger, who designed Einar's laboratory and film posters, created a three-dimensional space that echoes this compressed cubist space. The set looks completely flat, until Einar and Claire start moving through it, and then the space suddenly has depth, while maintaining its cubist character. (Figure 16) This trick of the set design and camera together alone make a case for viewing this film. The actors are what take this 
set piece-turned painting, and turn it into an experiential, "real" space by moving through and experiencing it.

Both lead actors, Georgette Leblanc and Jacque Catelain, were varying degrees of queer. Leblanc was a known bisexual and had a long term, non-monogamous, lesbian relationship with a well-known magazine editor at the time. Catelain has been said to have engaged in a prolonged affair with his longtime friend and collaborator, Marcel L'Herbier. Even if this particular scandal has little evidence to support it, the film provides moments of quietly linking Catelain and queerness. Given the queer histories of these actors, combined with an unconvincing romantic plot, there have been a number of recent analyses of this movie as a queer film. This includes Maureen Shanahan’s 2004 essay, “Indeterminate and Inhuman: Georgette Leblanc in L'Inhumaine (1924)."’3 Shanahan's essay attempts to bring Leblanc's considerable contributions into the discussion of the film, which often gets reduced to phrases like, "she was too old for her co-star" and "this movie gives vanity projects a bad name." Shanahan then examines the film through the view of potentially queer contemporary audience, who might have understood quiet references to gay culture, unnoticed by those unfamiliar with it.

But what is missing here is, of course, the architecture. It is clearly a central part of the film's appeal, and yet the architectural spaces are framed in terms of "her space", seen in Figure 9 versus "his space," which can be seen in Figure 16. This is rudimentary, as far as architectural analysis of space goes. The most striking thing about these "home" spaces is how undomesticated they are. In both cases, the homes are primarily spaces of work. In this respect, both of these homes are extensions of the work-driven main characters - their work is supposed to be their lives. We can also see this in Einar's home, which is entirely devoted to science. It is

${ }^{3}$ Shanahan, "Indeterminate and Inhuman." 
just a series of artistic-looking laboratories, filled to the brim with dangerous machines and futuristic technologies. The architecture does not underscore the domesticity and heteronormativity of these so-called "homes," but rather, serves to reinforce their individual devotion to their work. Claire enjoys doing intimate performances and entertaining guests on her variety of small stages, while Einar is so enthralled with his work at home that he loses track of time, and is late to the opening dinner party. Both characters are defined by their work, and their respective spaces reflect that passion.

Claire's mansion, seen in Figure 9 is supposed to be sited at the top of a hill in the outskirts of Paris. The exterior was designed by Robert Mallet-Stevens, one of a handful of artists and designers to work on the film. It features a circular driveway for cars, and a variety of geometric volumes, illuminated by glass-block windows, featuring a striking geometric front door, with ornamental patterns on the corners of one of the volumes. The front door has two lights, reminiscent of marquee lights on either side of it, hinting at the theatrics on the interior. Inside, there is an entryway that leads into a large hall with a fountain that serves as a moat for the central stage, as illustrated by Error! Reference source not found., which is used for both dinner and acrobatic performances. On stage right of the room, there is an elevated stage where a jazz band plays. On stage left, there is an alcove with couches and chairs, so that Claire's guests may enjoy an intimate concert from the singer. The back of the room has two flights of stairs. There is also a winter garden that connects to the room beyond the stairs. Claire is clearly shown enjoying the performances on the center stage while in the winter garden. Somewhere off of this passageway from the garden to grand hall is Claire's private quarters, with art and furniture. We only see it in isolation from the other rooms, and it is the only room where visitors are not welcome. In an emotional cue to this room being her quarters, it is the only place we see Claire 
shaken up over the after the initial announcement of Einar's apparent suicide. These private quarters and her dressing room at the opera are the only places she is familiar with and feel safe to lose her composure.

This composure is where the phrase "inhuman" comes from. Claire laughs off Einar's initial declaration of suicide. She easily rebuffs suitors, and chose to go on with the concert, despite being accused of causing Einar's death. She maintains her composure in front of the world, but when faced with her fears in the strange morgue, her imagination and emotions get the best of her, and she cries hysterically until Einar reveals himself to her. Her problem is not that she is ruthless, it is a perception issue. At the end she said to Einar, after he's revived her, in the dramatic scene, seen in Figure 18, "I only did it for the love of... humanity."

In Claire's home, Einar is shy, hesitant. After arriving late to dinner, he hovers, unsure of whether or not to be so bold as to barge in right in the middle of dinner.

In her home, Claire is the one in charge. As shown in Error! Reference source not found., we can see that her chair is central and taller than the others, she entertains guests, and has the autonomy to reject them. It is implied that this sort of flirtatious salon is a regular occurrence. The space feels more like a glamorous social club than a home. Like any good entertaining space, there is plenty of room for lots of guests, but the house creates moments of privacy. The winter garden is the best example of this, where the vegetation is so thick, Einar and Claire's conversation there seem all the more intimate. Claire's central stage has a black-andwhite geometric chevron pattern, and when the table is set with her chair, the tallest, in the middle she seems as if she is the Queen of her own chess board, no King needed, but plenty applying for the job. She commands a small army of masked servants, so as to ensure their constant smiling and discretion. Claire employs a number of performers, including a full jazz 
band, as well as a juggling act and fire-breathers. These performers and servants make sure Claire's party is well orchestrated, with Claire as the stage director and lead talent.

The element of the embedded fountain (complete with live waterfowl) in this very theatrical home is very reminiscent of Frank Lloyd Wright's Barnsdall/Hollyhock House (1919), shown in Figure 12. The Barnsdall House was built for Aline Barnsdall, an unmarried woman with her own theater company, who liked to keep the company of radicals like Emma Goldman. Alice Friedman, in her book Women and the Making of the Modern House (1998), describes the Barnsdall house as such, “...a house built not for the private life of a family but as a residential centerpiece... its large, formal spaces and evident lack of domestic feeling reflect this program."4 The Barnsdall House also features, "various stages and dramatic settings in and around the house". 5 I do not mean to imply that Cavalcanti (the designer of Claire's Grand Hall and winter garden) was necessarily looking at the Hollyhock House as a precedent, but that Friedman's work is a precedent for thinking about Claire Lescot's fictional home. Friedman asserts that Wright and Barnsdall did not see eye-to-eye on what the house was exactly for, with Wright attributing the "failure of the Olive Hill project on Barnsdall's feminine susceptibility to 'advice..."". 6 The Barnsdall House pushed design and programmatic boundaries because an unusual client asked for an unusual space. When the experiment failed, to save his reputation, Wright placed his share of blame on his alternative client, rather than his own contributions to the problem. ${ }^{7}$ There are many similarities between the Barnsdall House and Leblanc's patronage of L'Inhumaine.

\footnotetext{
${ }^{4}$ Friedman, Women and the Making of the Modern House.

${ }^{5}$ Ibid.

${ }^{6}$ Ibid.

${ }^{7}$ Ibid.
} 
The designers of L'Inhumaine had similar complaints with the producer and star, Georgette Leblanc. Claude Autant-Lara, according to Shanahan, nicknamed Leblanc, "la dame avec les dollars" and found that L'Herbier seemed to bend over backwards to fit her into the “scenario for L'Inhumaine". ${ }^{8}$ L'Herbier himself later said that Leblanc was obsessed with "questions of appearance" and did not partake in the actual production work of the film. In addition, Leblanc was considerably older than her costar, Jacque Catelain, who presented himself as an ephebe, styled as similar to a contemporary ballet dancer. This visually mismatched pair, if the ages were reversed, would be seen as totally acceptable. Still, many of the critiques of the film's narrative focus on the age difference.

When considering for whom the film was designed, the lines of patronage are not nearly so clearly defined as with built architecture. Was Claire's space designed for the character, or was it designed under the influence of Leblanc for Claire? Was Leblanc even consulted? It is hard to say. But, Shanahan points out that Leblanc saw herself in Claire Lescot, to the point of changing the title of the film from Femme de glace to L'Inhumaine, and she referenced her character in one of her autobiographies. Because of this, it is difficult to say to what extent critiques of the film are addressing Leblanc's character and performance, or the very nature of Leblanc's involvement. Perhaps Leblanc's involvement with a prominent woman (Margaret Anderson, also an acquaintance of Aline Barnsdall) plays into the reading of Claire's rejection of suitors to the point of seeming "inhuman." Claire then unconvincingly settles for the man who has styled himself like a popular ballet dancer, in order to access his work, which will benefit her work. There is little wonder the two have no on-screen chemistry to speak of.

${ }^{8}$ Shanahan, "Indeterminate and Inhuman." 
Einar's home is referred to as such only once. When Claire arrives the first time, the intertitles call it, "the strange laboratory." This reinforces the fact that Claire has been brought to his home under false pretenses. The second reference to Einar's abode is when she tells the taxi driver to "go to the home of Mr. Norsen." But the language is very interesting. It does appear to operate as both a kind of home and strange laboratory at the same time. This simultaneity of "strange laboratory" and an assumed, but never shown, private space for Einar and his assistants make for an untraditional creation. We never see the private space, but perhaps we are not meant to, for a variety of reasons. A feminist reading might argue that women's privacy is always accessible to more than merely the women who occupy a given space. Perhaps Leblanc asked specifically for private quarters to be in a scene. Einar does not have the motivation for keeping his emotions concealed. We see Catelain go to great lengths to show the audience his inner turmoil. He might not require a display of interiority and privacy, because he is a modern man, consumed by his love for Claire and his work. Einar's living situation was not extrapolated, nor were the exploration of his private quarters necessary to the story. While these spaces are not entirely equivalent, there are enough programmatic similarities that it is worth pointing out when there is a lack.

Einar's house is another geometric array of white blocks. His house is more reserved than Claire's, but that reflects his character's shy countenance and social standing. There is a massive tower above the front door. It was built, shown in the initial shot of the exterior, and then never mentioned again. This is interesting on a more trivial level, given that Mallet-Stevens built a real house with a very similar tower element. There is one double-height window next to the front door, which is up a single step, instead of the small flight of stairs to enter Claire's Mansion. The first time we see the house, Einar is speeding off in his Bugatti sports car to Claire's soirée. 
There is a man in a white jumpsuit and a black helmet or mask inexplicably standing and, perhaps, working, on the roof of the house. The inside of Einar's house is far from legible as the exterior. They are entirely separate entities.

The exterior does not, in any way, relate to the supposed interior of the building, though from a production point of view, it is hardly worth the effort to create an almost life-sized model of an ultra-modern home, only to have the stylistic characteristics change the exterior. Film is a space for architectural experimentation. If the exterior does not need to reflect anything but pure imaginary modern architecture, then there is little use in being so perfectionist. In fact, different designers worked on different spaces. Mallet-Stevens, the only architect amongst the set designers, created the exterior models of these houses. Other designers were in charge of different rooms, so it makes sense that the final result is not so much a cohesive built structure, but a series of cutting-edge decorated spaces, brought together by the narrative and camera.

Inside Einar's home, there are at least five distinct rooms: an entrance hall and stair, two laboratories, a room used as a morgue, and the room where the miraculous resurrection takes place. These spaces are full of "scientific" bric-a-brac, and are not as clearly legible as Claire's grand hall with garden plan. In Claire's space, I could easily see how the rooms might be spatially situated. Einar's home is full of twists and turns, stairs for dramatic entrances, as well as curtains, places for dramatic effect. I had to wait for around four different viewing angles in order to fully understand all of the doors and openings in the Morgue, in particular. This might suggest, from a literary perspective, that Einar is more complicated than the audience or Claire expected. Claire assumes he is a cowardly, emotional young man, unworthy of her affection and talents. He devises a devious plan to trick her into intrigue, and then seals her attention with his 
marvelous television device. He does not need to be masculine, rich, or powerful when he has futuristic technology to woo his beloved.

So, despite this seeming mismatched, this couple, clad in couture, patrons of modern art and science, find solace in their platonic partnership. The story works better in the frame of the 1925 L'Exposition internationale des arts décoratifs et industriels modernes, where many of the contributing artists exhibited their most avant-garde work. L'Inhumaine was re-released during the Expo, this time to great acclaim. To designers and artists, the film was about the unlikely pairing of new technologies and the Grand Dame of Art (depicted in the film as a kind of nod to Symbolist Salome or Sarah Bernhardt) to reach the rest of the world, particularly Colonial holdings. When the expectation for traditional romance in the plot is put aside, the story and visuals can speak for themselves, to great effect.

In this chapter, we saw the ways in which L'Herbier and Mallet-Stevens created a world in which the architecture related to the characters' development, almost as if the architecture was representative of the character the same way that costume, dialogue, or any other storytelling device might build the characters. We also explored the ways in which this love was an asexual love, motivated more by a desire to make something new than to make a traditional love story. This applies to both the characters and the filmmakers. 


\section{Chapter 3: Villa Noailles}

In the previous chapter, we explored architecture that was created for the camera's eye to create space and the reality of the screened world. In this chapter, we will reverse the process, discussing a work that was created and then shaped by the camera's eye.

In this chapter, I will provide a history of the Villa Noailles, then reframe the traditional narratives of the site to include the queer history of its patrons and designers, particularly the contributions of Marie-Laure de Noailles. By examining the Villa Noailles as a site of experimental living, both as a Modernist architectural site as well as a locus of early 20th century counter culture, we can better understand how media and architecture interact with patronage, conceptions of "modernity", and creation of lifestyles outside of heteronormative traditions. Before we get to this social and cultural analysis, we must understand the site history of the Villa Noailles.

The Villa Noailles was commissioned by the newlywed Vicomte and Vicomtesse de Noailles, Charles and Marie-Laure in 1923, after they returned from their honeymoon. ${ }^{1}$ They chose the architect and set designer Robert Mallet-Stevens after being turned down by Mies van der Rohe and turned off by Le Corbusier. The Hyères commission was also after Jean-Michel Frank (1895-1941), an interior designer, and the young couple redecorated Marie-Laure's

Parisian hôtel at 11 Place des États-Unis in a stark palette of white walls and geometric furniture. The site of the Villa Noailles, like the 11 Place des États-Unis, was given to the newlyweds by their parents. The hôtel was a gift from Marie-Laure's wealthy French aristocratic and GermanJewish parents. Charles' mother, the Princesse de Poix, gifted the couple the site for their future

\footnotetext{
${ }^{1}$ Francine du Plessix Gray, "The Surrealists' Muse," The New Yorker, no. September 24, 2007 (September 24, 2007), http://www.newyorker.com/magazine/2007/09/24/the-surrealists-muse.
} 
winter home in the hills overlooking the small coastal town of Hyères in the south of France on the site of the ruins of a medieval castle.

The new building, first inhabited in 1925, with construction ongoing in fits and starts until 1933, was placed downhill from the ruins of the abbey. The dovecotes and walls are extant on the edge of the new construction. The juxtaposition of the ruins of the Abbey with the cubist volumes and almost pink reinforced concrete enhanced the projected Modernity of the project. The whole site is supposed to assert the modernity and avant-garde nature of this architectural project in comparison to the ruins, now a folly. These comparisons of modern and traditional can also be seen in the gardens of the house. Next to the house, off of the main lawn, and lower salon, Armenian landscape architect Gabriel Guévrékian (1892-1970) created a “cubist garden" (seen in Error! Reference source not found. and Figure 38), with a variety of plants, mirrors, and fountains to create a new type of garden, in between sculpture, horticulture, and architectural playground. The lower part of the property was given over to the creation of the Parc Saint Bernard, a botanic garden, which was a series of terraces built by Mallet-Stevens, and cultivated by Charles de Noailles. Parc St Bernard was a public garden, and is much more "naturalistic" than the cubist garden closer to the house. ${ }^{2}$ It features pathways between the subtle terracing and the vernacular Mediterranean plants, which provided shade to the visitors and exhibited the Viscomte's horticultural expertise and the region's bounty.

Hyères and the Var region in Provence-Alpes-Côte d'Azur (Southern France) is known for its balmy weather and its production of fruit and flowers. This was perfect for Charles, an avid aristocrat-gardener who, according to Dorothée Imbert in her book The Modernist Garden

\footnotetext{
${ }^{2}$ Charles Noailles and Roy Lancaster, Mediterranean Plants and Gardens (Calverton: Floraprint Ltd., 1977).
} 
in France, "eventually became vice-president of the Royal Horticultural Society in London and honorary president of both the International Dendrology Society and the Société Française des Amateurs de Jardins." 3 The experimental and Mediterranean gardens surrounding the Villa Noailles were Charles's domain. To quote Francine du Plessix Gray from her 2007 retrospective profile of Marie-Laure in the New Yorker, "WWho does Charles like best, men or women,?" a friend once asked Marie-Laure. "He likes flowers," she answered.' ${ }^{4}$ Charles is also known for restoring the 18th Century gardens at Fontainebleau, where he "... planted scented flowers beneath the guest room windows so when they were opened in the morning, guests would smell their fragrance." While the Villa Noailles does not situate the gardens close enough to the bedrooms to catch the fragrance of the flowers in the garden, later additions created a flowered terrace outside of each ensuite guest room. The inclusion of flowers were brought into the main house, where space is much more limited. Off of the main foyer, there is a small room, maybe four feet by four feet, called the salle des fleurs (seen in Error! Reference source not found.) that was used for creating flower arrangements. The salle des fleurs has little more than a sink and a window in it, but it was important enough to be placed centrally in the Villa, and it was painted in the de Stijl style by Theo van Doesburg in 1925. Whether the salle des fleurs was actually used by the staff or the Noailles is unknown to me. However, its inclusion highlights the importance of these flower arrangements were to the hospitality of the couple, as well as enforces the concept of the Villa Noailles intentionally brought nature into their home.

Mallet-Stevens, the architect, understood that his job was to create a space that was not meant to obscure the view but to choose a view, and frame it. The architect is quoted by Léon

\footnotetext{
${ }^{3}$ Dorothee Imbert, The Modernist Garden in France (New Haven: Yale University Press, 1993). ${ }^{4}$ du Plessix Gray, "The Surrealists' Muse."

${ }^{5}$ Ibid.
} 
Deshaires, in his 1928 essay on the Villa Noailles in Art et Décoration, saying the wall surrounding the south terrace, "Like certain Italian convents, it is perforated with large bays which frame a chosen view of the countryside. ${ }^{\prime 6}$ In this quote, we see Mallet-Stevens as an architect who is keenly aware of the siting of the building, and its owners desire to get the most out of their expansive viewsheds. These perforated "convent" walls are interesting because they operate the same way that a camera's view-finder does, making these "chosen views" the creation of their director, in this case, Mallet-Stevens. This wall presents a point of interaction between Mallet-Stevens' work as a set designer, someone who would need to be aware of how the camera constructs views, and how the viewer might adopt the logic of the camera. The whole house is constructed in this way-a photogenic creation. When one is walking through the building, there are moments when a hallway lines up just so, or a window is placed just so that one can see the curve of the mountain and the sparkle of the distant water. It is certainly labyrinthine, which was both a virtue of the original plan and the result of renovations and additions over the years.

The Villa Noailles was designed by Mallet-Stevens and the couple to be their retreat from the city. Some accounts call it a "winter house," while others call it a "summer residence". This discrepancy is probably due to the occupation of the Villa shifting from its initial inception. Either way, the consistently balmy Hyères ensured that any season would be comfortable for the Noailles and their guests. The parti, or simple statement, of the Villa Noailles is the conception of a stationary or sometimes stranded ocean liner. The Ocean Liner, especially in the context of modern architecture consciously projecting "modernity" is, of course, an inspiration for change in Le Corbusier's 1923 manifesto Vers une architecture, in the section entitled, "Eyes that do not

\footnotetext{
${ }^{6}$ Pinchon, Rob. Mallet-Stevens.
} 
see, part I: Ocean Liners". In the essay (which was published in 1920, three years earlier than this edited volume) Le Corbusier discusses the ways in which architecture has stagnated while visually encouraging comparison to the design of ocean liners, which use space efficiently and are not beholden to things like tradition and decoration, or the architectural academic tradition. If we combine this ocean-liner aesthetic with the influence of the Josef Hoff we start to see the Villa's visual points of inspiration. The central tower, a common feature in Mallet-Stevens' paper and cinematic architecture, was an important element to Mallet-Stevens's design at Hyères. We can see an iteration of this central tower in the 1924 film L'Inhumaine where the tower of Einar Norsen's home is so large the camera has to pan down to see the actors. This experiment is different than the experimental central tower of his paper architecture because the camera acts as an eye to create a way of simulating the experience of looking at such a tall tower. In a 1977 letter, the Viscomte recalls the original version of the "narrow square tower" decoration:

He had imagined decorating the house with a narrow square tower - which I approved of - but wanted to finish off its white vertical with something dark. Which resulted in a cantilevered roof with an empty space underneath. After three years, I told him that I could not get used to this roof which resembled a visor on a helmet and with his agreement the roof was removed. The tower has been left the same, with two rectangular openings which allow one to enjoy the view. ${ }^{7}$

This kind of negotiation and thematization is likely when dealing with matters of experimental architecture. Sometimes what works on paper or film may not be appealing to live with on a regular basis, as is evidenced in this letter. Keeping in mind that the Villa Noailles was MalletStevens's first building commission, experiments like the tower's cantilevered visor were exactly

\footnotetext{
${ }^{7}$ Deshoulières and Jeanneau, "Description by the Viscount de Noailles of the Construction of His Villa in Hyères - 1977.”
} 
that- experiments. This negotiation between the patrons and the architect is exactly the kind of work that Friedman uses as evidence to explore the ways in which the patrons in classic modern architectural buildings shaped the programs of the forms of the buildings. ${ }^{8}$

The Noailles envisioned a lifestyle shaped by the ocean liner: a life of luxury, exercise, heliotropism, celebration of nature, and collectivism. ${ }^{9}$ What started out as a small house retreat ballooned into a forty-plus room destination for the Noailles and their guests. ${ }^{10}$ These guests fall into certain categories: designers, Surrealists, and sculptors. There are also mentions of poets, painters, and musicians who visited, but in terms of the creation of the Villa's modernist gesamtkunstwerk aesthetic, these are the guests that fall under our purview. According to Kim Knowles in her book on Man Ray's filmmaking, the invitation to Man Ray was to stay the winter at the Villa in exchange to creating the film. ${ }^{11}$ This aspect of the villa as a private retreat for patrons to extend hospitality in exchange for services further reinforces the Villa's role as a set for the Noailles to follow their personal passions, rather than focusing on conservative domestic bliss.

These guests were often artists the Noailles were patronizing in one way or another. Some of these artists, like the previously mentioned Theo van Doesburg, were working on-site at the Villa. These artistic guests, many of whom were a part of Mallet-Stevens' circle (and a part of the professional union he founded, the Union Artistes Modern, or UAM) and recommended

\footnotetext{
${ }^{8}$ Friedman, Women and the Making of the Modern House.

${ }^{9}$ du Plessix Gray, "The Surrealists' Muse."

${ }^{10}$ Shane Maree Dunworth, "The de Noailles as Collectors and Patrons." (Courtauld Institute of Art, 1985).

${ }^{11}$ Kim Knowles, "From Mallarmé to Mallet-Stevens: Reading Architectural Space in Man Ray's Les Mystères Du Château Du Dé,” French Studies: A Quarterly Review 65, no. 4 (October 2011): 459-70.
} 
for patronage at the Villa Noailles. ${ }^{12}$ These designers and their custom work for the Villa

Noailles is part of what makes the Villa such a success, and helped to establish UAM.

Man Ray's film, Les mystères de château du dé13 is Man Ray’s longest and last film. The mythology behind the inspiration for the link to Mallarme's poem Un coup de dé was from images of the villa itself, sent along by Charles de Noailles to Man Ray as a way of enticing him out of filmmaking retirement. Man Ray capitulated after being told that the film would have a private release, in addition to the winter retreat. ${ }^{14}$ The film itself is a pastiche of documentarystyle footage of the villa, intertitles interpolating Mallarme's poem, and the hosts and guests of the Villa Noailles dressed in bathing suits with stockings over their heads. In her chapter for Architecture and Cubism, Beatriz Colomina opens her discussion of the relationship between architecture and cubism by referencing this film. "This displacement is made literal in Man Ray's film Les mystères $d u$ château du dé, where at a certain point the visitors occupying Mallet Stevens' Villa Noailles ask themselves the all too 'human question: where are we?'”

Display is the other side of patronage. As a benefactor of the arts, one of the benefits of owning custom objects and being regarded as someone with "taste," is the excuse to display and publicize those objects, especially when the purpose of the home is to host visiting artists and taste-makers. Many people assume that it was Charles de Noailles who was the motivating force behind the Villa Noailles and its treasure trove of decorative arts. Megan Meulemans, in her feminist reframing of patronage in the work of Mallet-Stevens in the essay, "Exposing the Villa Noailles: The Women Behind the Promotion of Robert Mallet-Stevens”, argues that while

12 Deshoulières and Jeanneau, "Description by the Viscount de Noailles of the Construction of His Villa in Hyères - 1977."

${ }^{13}$ Man Ray, The Mysteries of the Chateau de De, Documentary, Short, (1929).

${ }^{14}$ Knowles, "From Mallarmé to Mallet-Stevens." 
Charles was the initial arbiter of the taste for modern art in the relationship and the one with whom Mallet-Stevens exchanged letters with, it was Marie-Laure who had the desire and drive to make her name associated with the patronage of modern and avant-garde $\operatorname{art} .{ }^{15}$ It was MarieLaure who invited Man Ray to create Les Mystères du Château de Dé, not Charles. Interestingly, this patronage and publicity extends far beyond their Hyères retreat.

This type of publicity: the lavish and grand parties (Meulemans describes them as "legendary"), aggressively funding and galavanting with a cadre of young (and often queer) artists of the avant-garde, created quite a bit of high society infamy for Marie-Laure. The story goes, that her boldness started in 1929 when she caught her husband in bed with the Villa's exercise instructor, and she ceased to be timid. The fact of the matter was that the Villa was never intended to be a domestic space. Often narratives balancing the Noailles and the Villa tend make sure to place the inception of the Villa right after Marie-Laure had her first child in 1924. By 1929, after she'd had her second child, the sexual portion of their relationship was over. ${ }^{16}$ After that, she kept a string of young, usually queer, men in her orbit, nurturing their rising artistic stardom. But the children are missing in the narrative of the Villa Noailles, at least. This lack of heteronormative or reproductive labor expected of the Villa and its inhabitants allowed for non-traditional ways of living to take shape. When one is free from reproductive labor, as the wealthy élites were, the choice of lifestyles becomes much broader. Charles, in his spaces (not just the Villa Noailles), was allowed to be both sexually active and work on his passion of horticulture. Marie-Laure, once free from the restrictions of traditional marriage, created a reputation for being a bizarre woman and muse of the Surrealists.

\footnotetext{
${ }^{15}$ Meulemans, "Exposing the Villa Noailles."

${ }^{16}$ du Plessix Gray, "The Surrealists’ Muse."
} 
One of the later additions (around 1928-9) to the house added a swimming pool, a squash court, and, a hair salon. Some say that the Villa was the first building in France to have a pool with a roof over it, and one of the few private residences with exercise facilities. ${ }^{17}$ In many accounts, including both (extant) movies filmed at the Villa Noailles were partaking in the mass ornament of exercise. This is especially clear in Jacque Manuel's film Biceps et Bijoux (1928), which features scenes of around eight people, wearing identical swimming suits, play games with exercise equipment (See, Figure 42). ${ }^{18}$ They put their feet together into a star shape, sitting on the porch, passing a number of heavy-looking balls around the circle, creating patterns and geometries with their bodies. This gender-neutral approach, where all participants wear the same clothes, and are not individualized, is different than contemporary films like L'Inhumaine (part of Mallet-Stevens circle) where the genders of the main characters are so clearly defined and reinforced through the narrative and decoration of the film. Here, Manuel, a L'Herbier protégé, and therefore in the Mallet-Stevens circle, creates a film that highlights the Villa's experimental machine for experimental living. In a small, intimate, loose film like Biceps et Bijoux, the audience is inherently different. Those who would disapprove of the bacchanalian lifestyle at the Villa were not likely to be welcome anyway. That convent screen with viewfinders were there to create vistas for the guests of the Villa, and to create privacy from potential voyeurs. The nature of privacy and publicity at the Villa Noailles is complicated. The nature of the house as a “stranded ocean liner" make it seem like the Villa was a private, self-sufficient space, existing apart from the rest of the town, the Vicomte and Vicomtesse aided by their on-hand staff of twenty to seem cut off from the rest of the town. But the very nature of the building, in the ruins

\footnotetext{
${ }^{17}$ Dunworth, "The de Noailles as Collectors and Patrons." NJacques Manuel, Biceps et Bijoux, 1928.
} 
of an abbey, this flamboyant cubist house dominates the viewshed of the town, and is easily seen from various points around the town. The Villa's main goal of blending into nature was easily perceived from those invited into the walls of the retreat, but from the rest of the town, the house, a light gray mass of blocks was almost always in their view. As the trees, and rest of the town have grown in, the house's dominant position has retreated somewhat. But the impulse for both publicity and privacy created a discursive effect on the house between its benefactors and its development.

We have lost some of the sense of privacy and intimacy at the Villa Noailles in the years between its role as a private entity and public gallery and museum. For instance, what I had assumed to be garages, underneath the front terrace, are shown by Manuel in Biceps et Bijoux to be elegantly appointed sitting rooms, cleverly put into the lower section of the house to keep these rooms cool and closer to the gardens than the upper pool and sunbathing area. This kind of quiet traditional space seems at odds with the publicity of the pool and sunbathing porch, where any noise made there can be heard by the rest of the complex. But this shows how photographs nor film cannot replace interacting with the architectural medium in the flesh.

By examining the patrons of the Villa Noailles, and why it was built, we can see an example of architectural patronage of non-reproductive spaces with the intent to have a place to follow passions, whether that was sexual, horticultural, or artistic. This new way of living, of course, was often temporary, so the experimental nature of the building's creation was mitigated by its secondary status of occupation for the Noailles, their art, and their guests. We see how Charles de Noailles' passion for horticulture and nature was a generative force in the theoretical conception of the building and grounds, while Marie-Laure was the creative force behind the modernist architectural and decorative project in the first place. Their desire for a space of 
artistic patronage, production, and publicity was inherent in Mallet-Stevens' design. We can see how Mallet-Stevens took this inaugural commission and building as a chance to experiment with elements of architecture he had explored in media architecture like cinema, models, and illustrations. Mallet-Stevens and the Noailles created a relationship where the experiments could be critiqued and remodeled to better suit those who experienced the space on a daily basis. This site is worthy of attention for at least these reasons, as it is a site of important artistic creation and patronage. Considering how the built environment shapes spaces for lifestyles outside of the heterosexual norms and how architecture and artistic patronage can bolster one another is an effort entirely worth pursuing. 


\section{Conclusion}

\section{State of the Villa Noailles}

It has only been until recently that the Villa Noailles itself has been recuperated. It is under the Patrimonie XX, an imprint of the French National Heritage campaign and governmental agency. Since the Villa's sale in the 1970s to the city of Hyères, it fell into disrepair during the 1980s and 1990s, partially due to cost of upkeep and the failings of the experimental concrete Mallet-Stevens used in its initial construction. But currently, the Villa Noailles is a house museum, educating visitors on Mallet-Stevens and the Noailles. It is also artistic exhibition space. When I visited in August 2016, the entire North wing was devoted to displaying current artworks from around Europe. The Villa has maintained its status as a locus of culture on the Côte d'Azur.

The Villa Noailles hosts an annual festival celebrating art, photography, architecture, and fashion. In 2015, Chanel hosted an exhibition of their archival pieces, as well as a fashion design competition, culminating in a party at the Villa Noailles. While some architectural historians go to great lengths to avoid the question of fashion and Mallet-Stevens, the Villa Noailles steams on ahead without them, entrenching this relationship with every passing year. The Villa is a favorite for fashion editorial shoots. Similarly, another tangential space that is reaching new viewers is Eileen Gray's E. 1027, which recently played host to a fashion campaign for the Stella McCartney brand for its Summer 2017 collection. In these cases of fashion appropriating modernist spaces, there is passing interest into the context and lineage of these spaces. E.1027's role in the campaign was reduced to a geotag on Instagram and a reference to Le Corbusier's time at the house, and the Villa Noailles is name-checked in the editorial credits. These passing flirtations of fashion media with works like the Villa Noailles and E. 1027 ignore the ways in which this alignment is radical: modern architecture that embraced its relationships between 
interior and exterior, architecture for queer occupants. I can only hope that increased visibility of spaces like the Villa Noailles turn greater attention to the potential for nuance and wide moments of intersection between often siloed spaces like fashion and architecture.

\section{State of L'Inhumaine}

In 2016, Lobster Films rereleased L'Inhumaine in high definition, complete with recolored film and a recreated version of the lost integral percussive score by Milhaud. Increased accessibility combined with the moment of rerelease increased awareness, prompting a new set of reviews to marvel over the aesthetics and denigrate the plot. But increased awareness and accessibility translates into more scholarship on the understudied queer aspects of the film, and Interwar cinema in general.

\section{State of Mallet-Stevens}

Studying Mallet-Stevens' work can help scholars understand how the canon of architectural greatness was constructed, and the implications of relegation on a work. His example also helps us understand how criticism, gender and sexuality dynamics within culture, especially in the face of experimentation that rejects canonical hegemony to create new forms and representations in architecture can impact the career and legacy of architects. His work also accesses questions of how media can reauthor space and how we understand architecture that has more visibility and access in two-dimensional print media (i.e. photography and fashion media) or multi-sensory media like film than in an experiential sense.

Most importantly, Mallet-Stevens' legacy and work accesses questions of how the camera and media can create experimental spaces, especially ones where there is no "real" space that it is referencing. Mallet-Stevens' early work intersects with interwar queer culture to open up discussions of how media and architecture interact and promote queer occupation of space. 
Most importantly, my thesis aims to show relationship between film and architecture by exploring the intersection of the two presented by Mallet-Stevens' work. In L'Inhumaine, I explored the way the camera created a cohesive space. In chapter two, I explored the Villa Noailles, which was not created for the camera, but created spaces that lent itself to the camera's eye regardless of Mallet-Stevens' insistence that his architecture was not equivalent to his set design. It also explored the ways in which subjective architecture, in both the film and the Villa Noailles were representative, embodied aspects of its patrons. Finally, I tied the thematic aspects of the two case studies through a feminist reading of the occupation of these spaces by their queer characters.

While I did not secure Mallet-Stevens' place in the canon, I hope I have shown a way in which his work might open up unique avenues into the relationship between architecture and the camera through the way that the Villa Noailles was transformed from a series of winding rooms into a series of striking stages for the films of Man Ray and Jacques Manuel. Architecture is a filmic media, and Mallet-Stevens' architecture shows that the relationship between film, set design, and architecture is a symbiotic one. To continue separating the two media is to avoid the new ways of seeing how the realm of the screen changes our relationship to the constructed environment. 
Illustrations

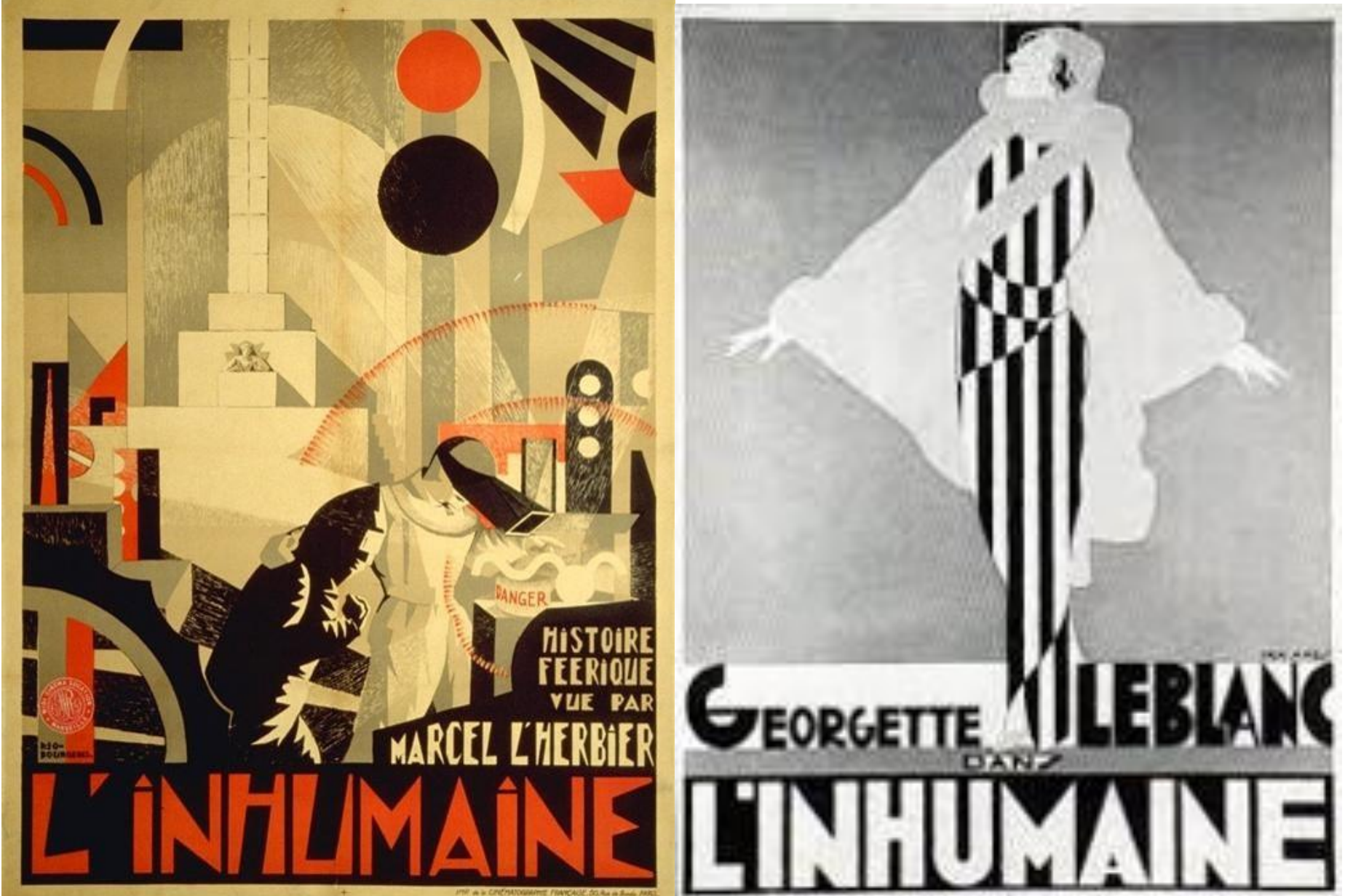

Figure 1: Posters, L'Inhumaine (1924)

Left: Poster for L'Inhumaine, designed by Djo Bourgeois, 1924

Right: Poster for L'Inhumaine, featuring Georgette Leblanc 


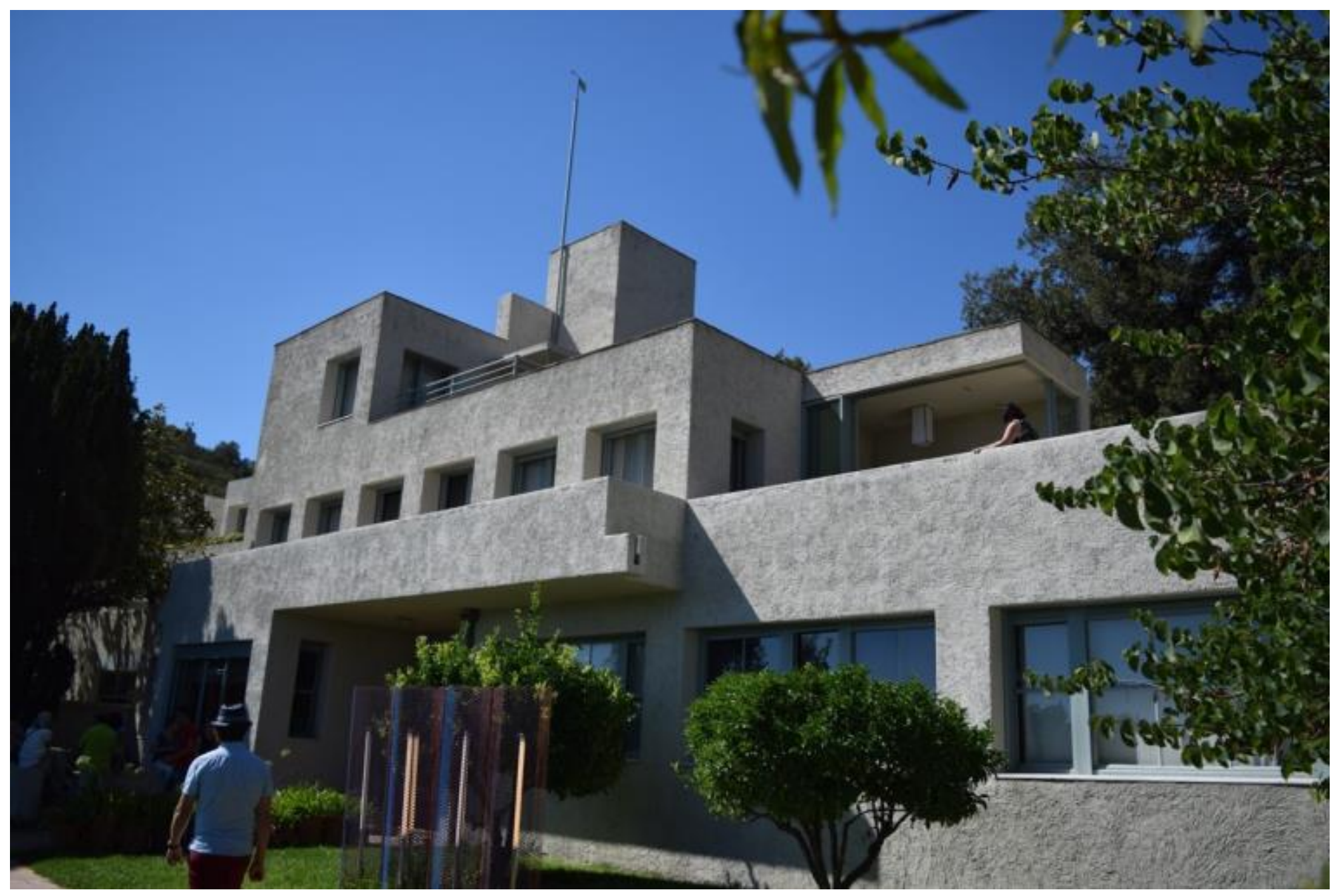

Figure 2: Entrance View

Villa Noailles, Façade, built, 1925, Photo: Author's Own, August 2016 


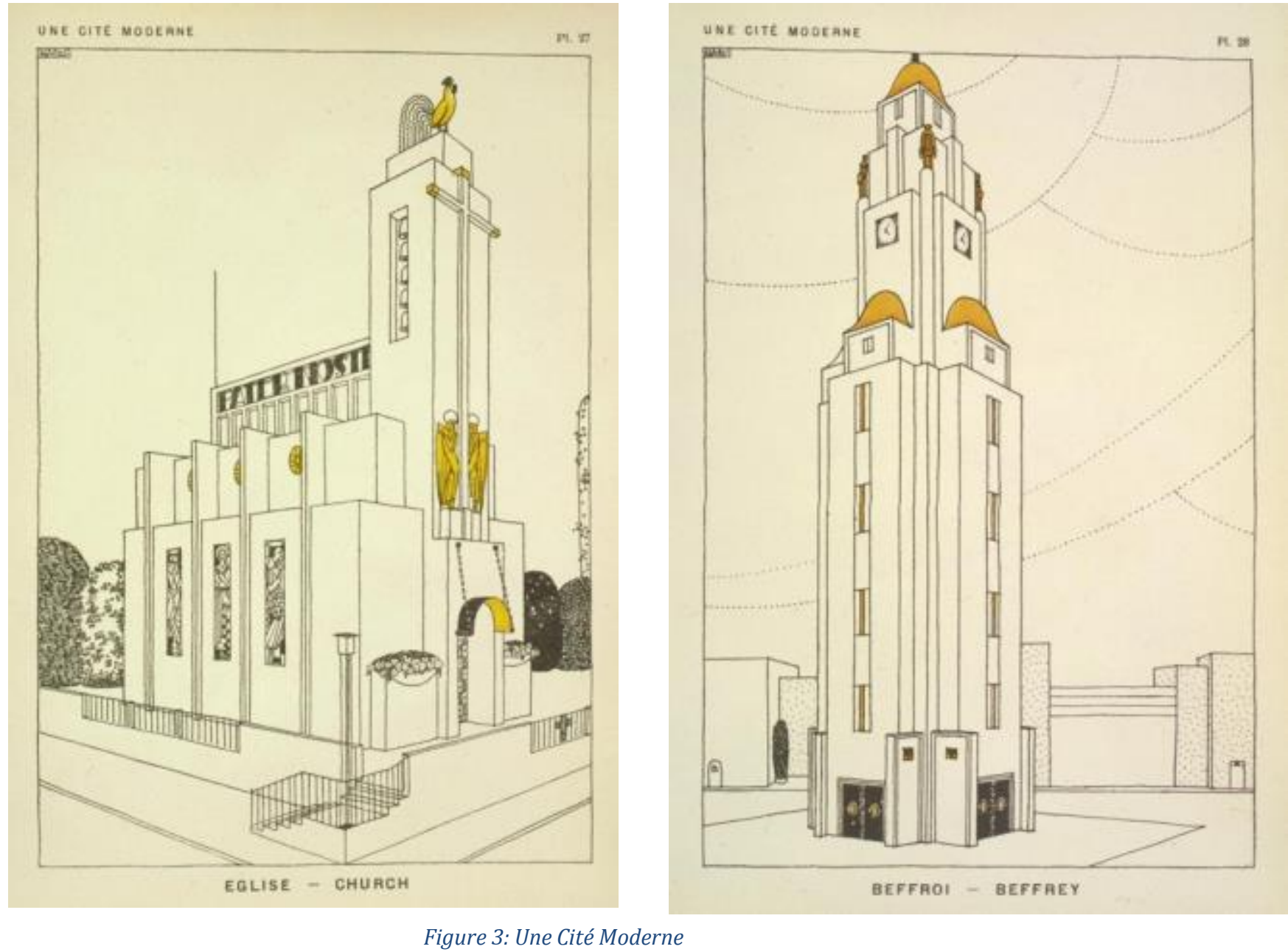

Illustrations of a Church and a Belfrey from Une Cité Moderne, Mallet-Stevens, 1922 


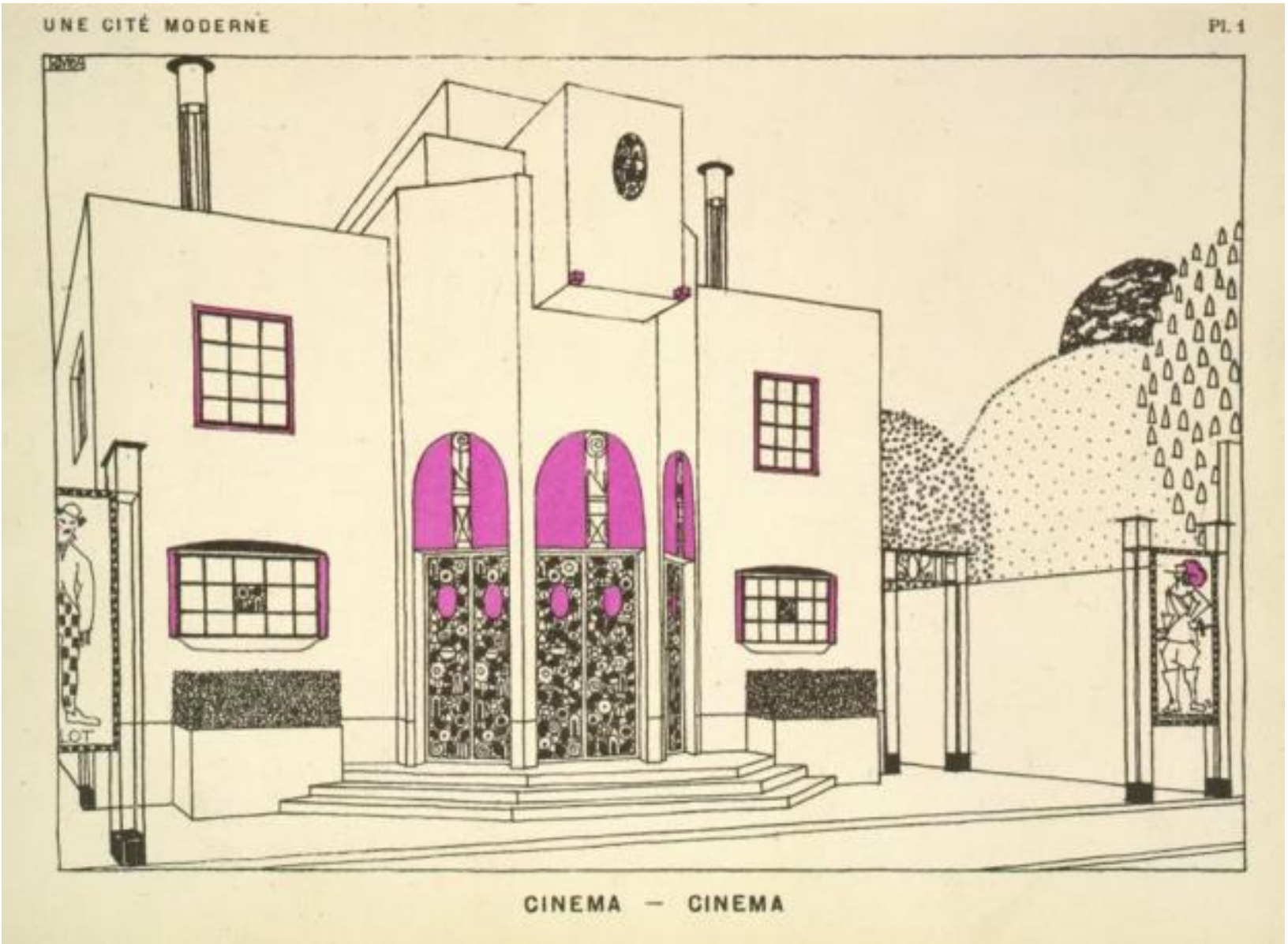

Figure 4: Une Cité Moderne,

Illustration of a Cinema from Une Cité Moderne, Mallet-Stevens, 1922 


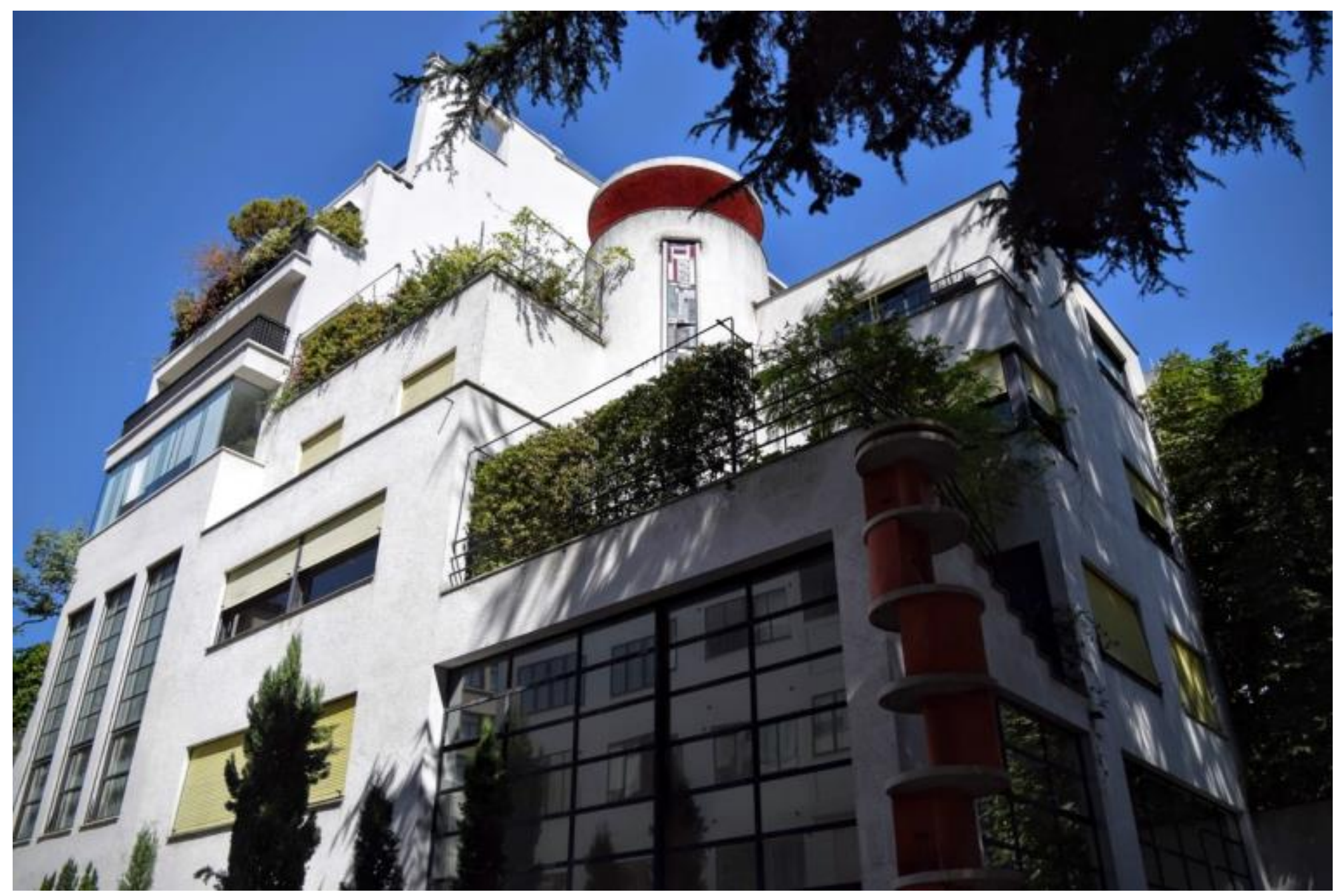

Figure 5 Rue Mallet-Stevens

Rue Mallet-Stevens, Paris, ca. 1927, Rob. Mallet-Stevens

Villa Martel and Villa Mallet-Stevens

Author's Photo, August 2016 


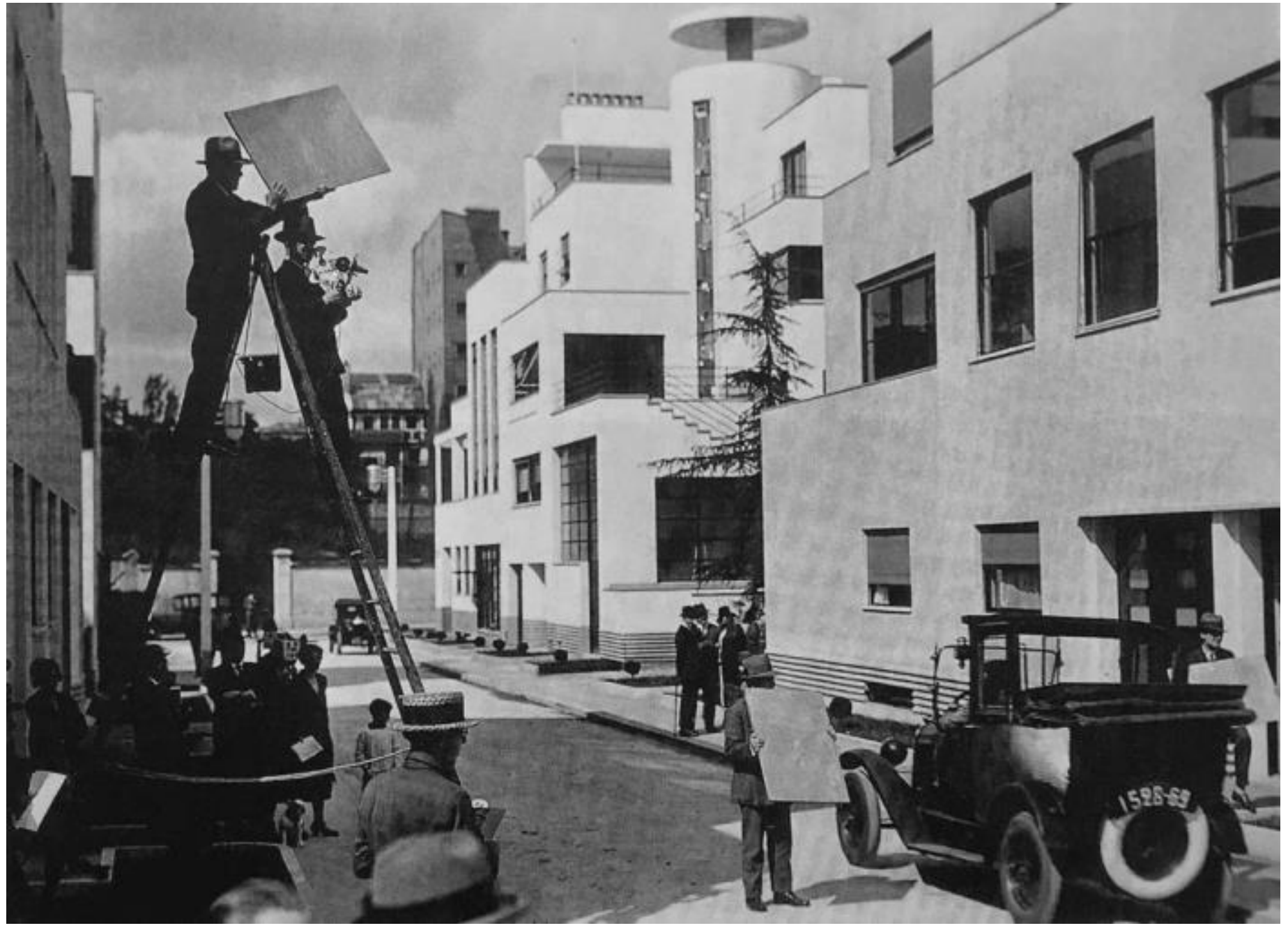

Figure 6: Rue Mallet-Stevens

Rue Mallet-Stevens, Filming La Sirene des Tropiques, a film Mallet-Stevens designed sets for Used in the film to denote how fashionable and well-off family is. Only shown for a brief moment. From: 

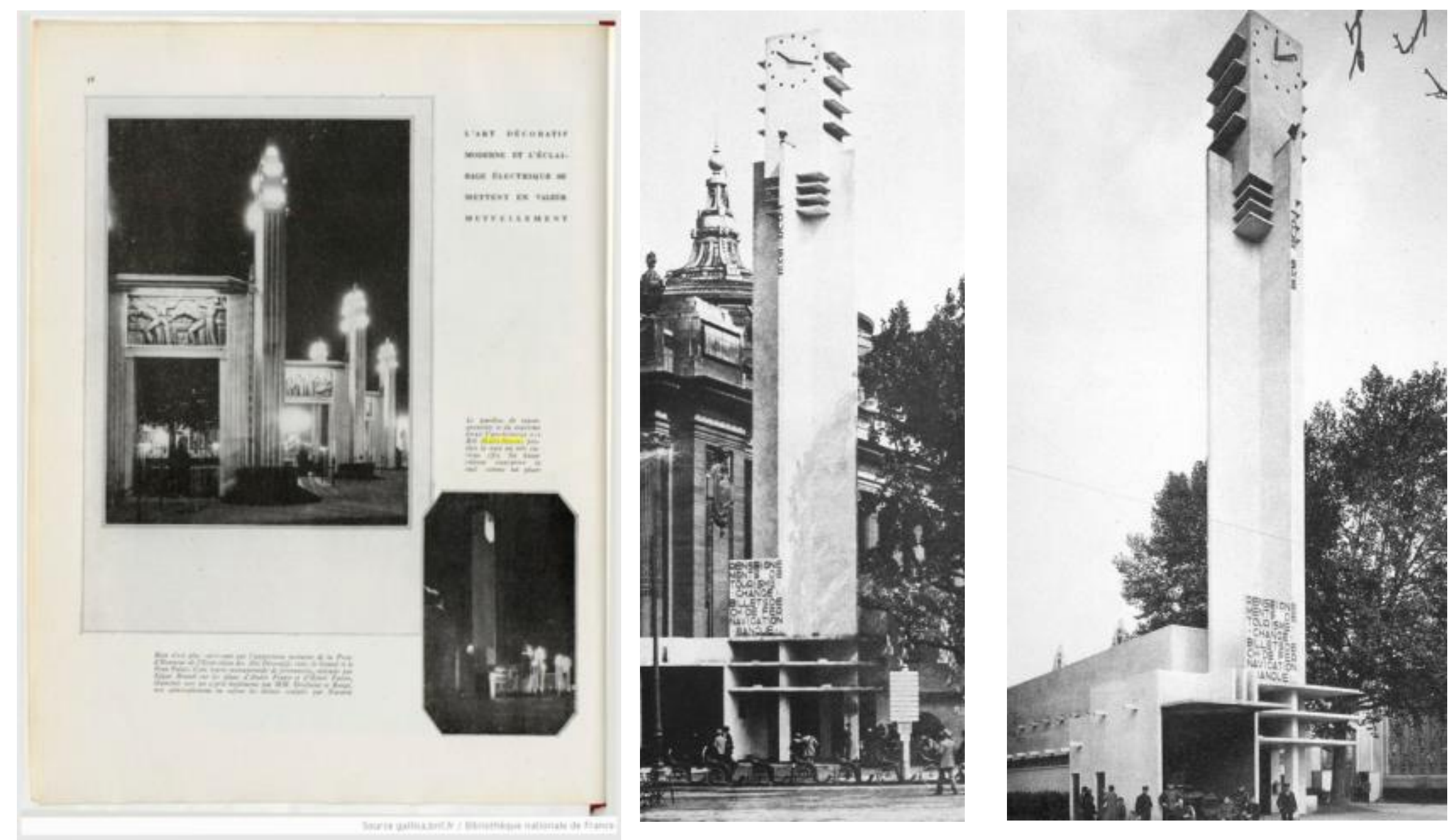

Left: Image from Vogue, 1925, Publicizing the $1925 \mathrm{Expo}^{1}$

Right: Mallet-Stevens, 1925 Expo, Pavilion du Tourisme, featuring central clock-tower motif

\footnotetext{
${ }^{1}$ Hornbeck, "Visions of Modernity."
} 


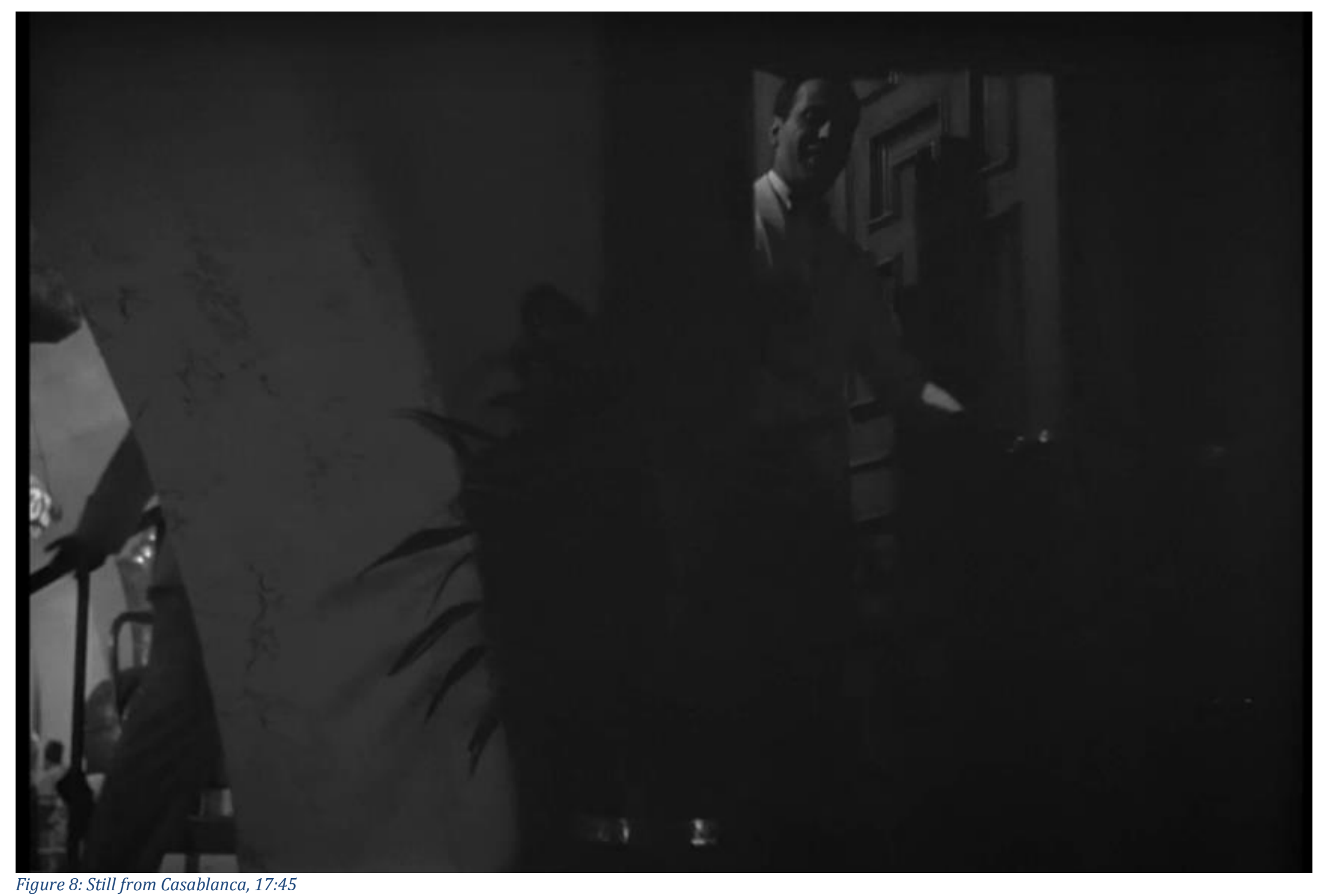




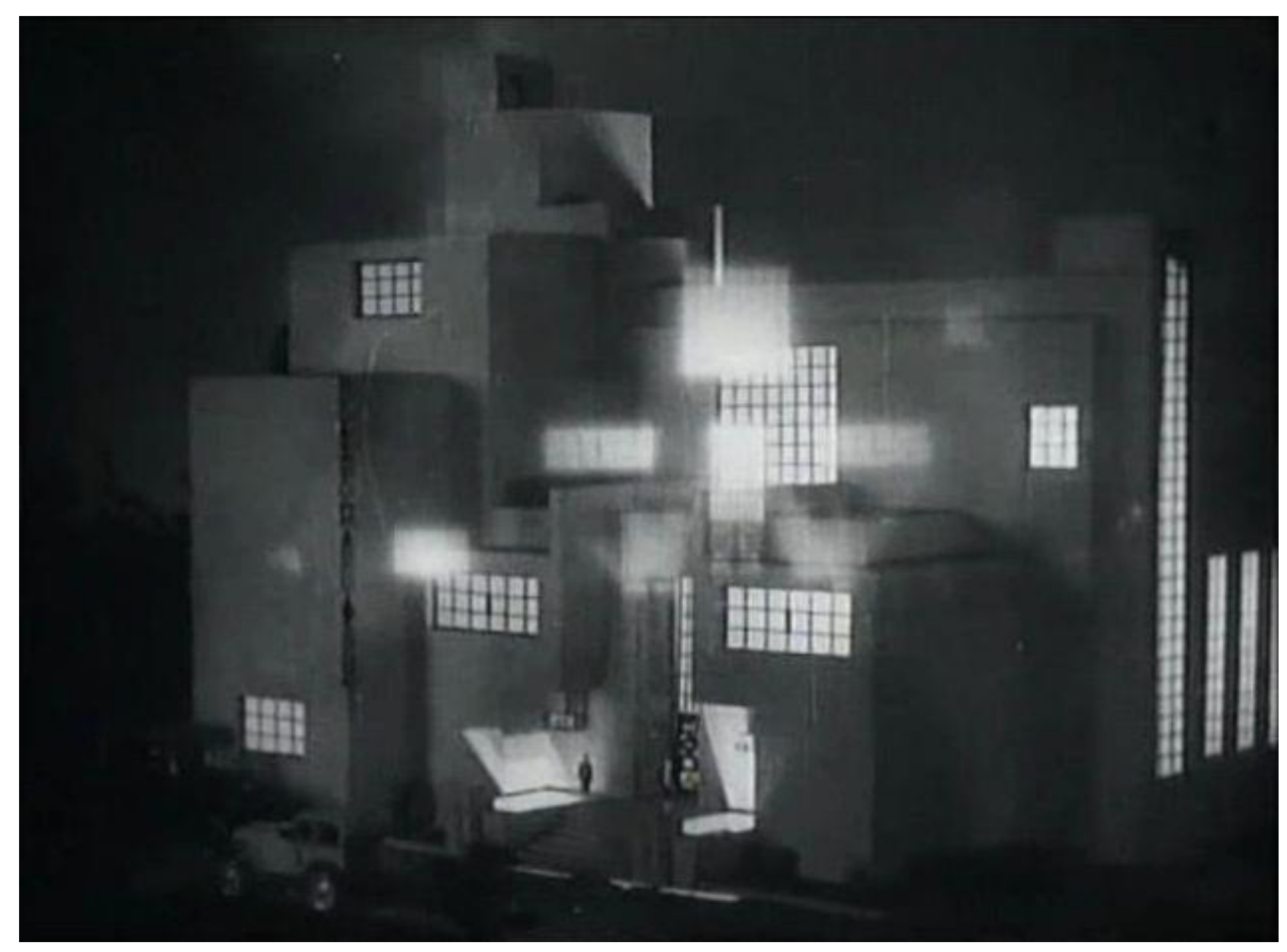

Figure 9: Claire Lescot's House

Model of Claire Lescot's Home

L'Inhumaine, 1924, Model by Mallet-Stevens

Notice Similar Massing of cubes to Villa Noailles 


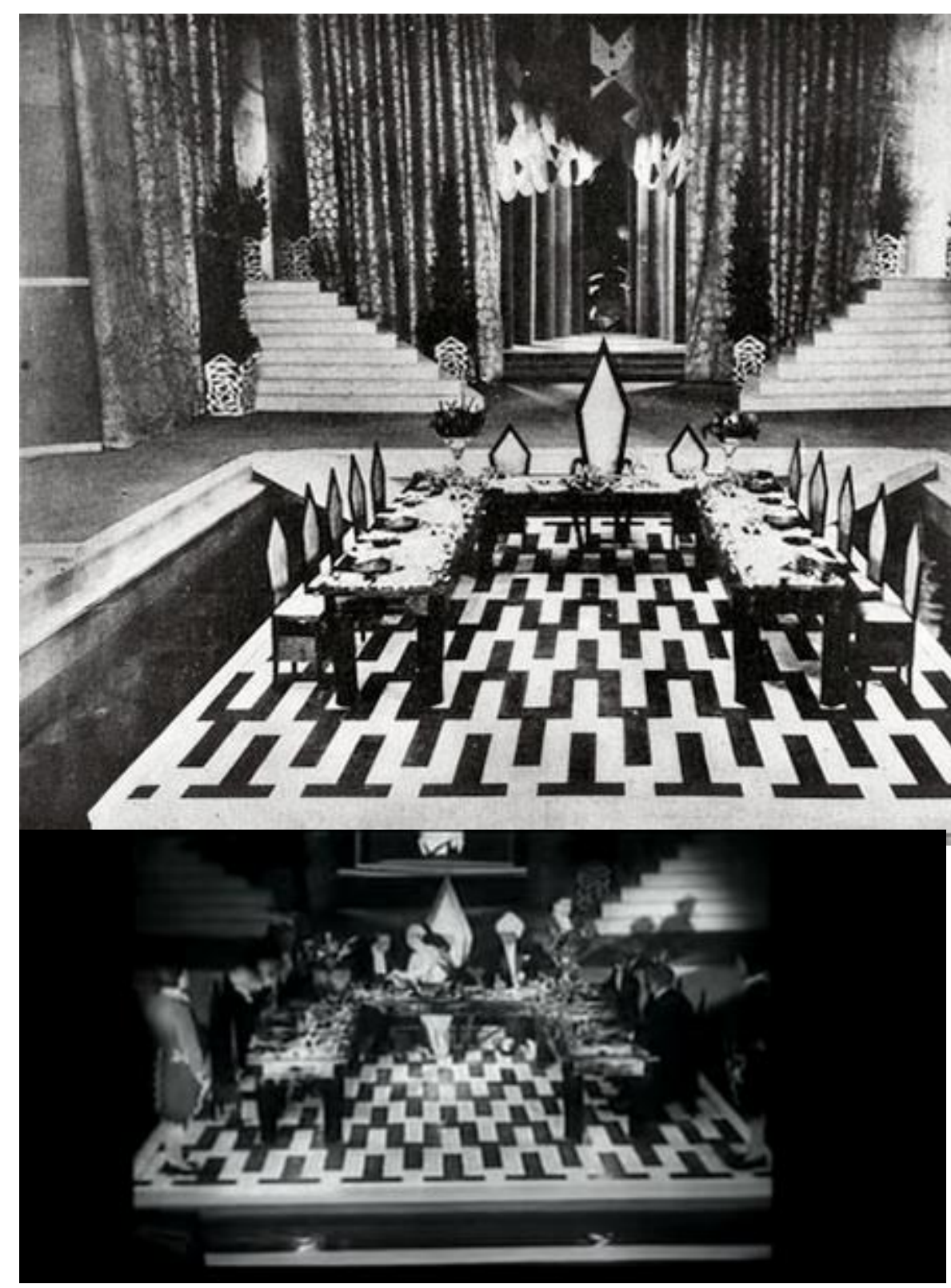

Set for Claire Lescot's Dinner Party Scene, Claire sits in the Middle

L'Inhumaine, 1924, Set by Claude AutantLaura 


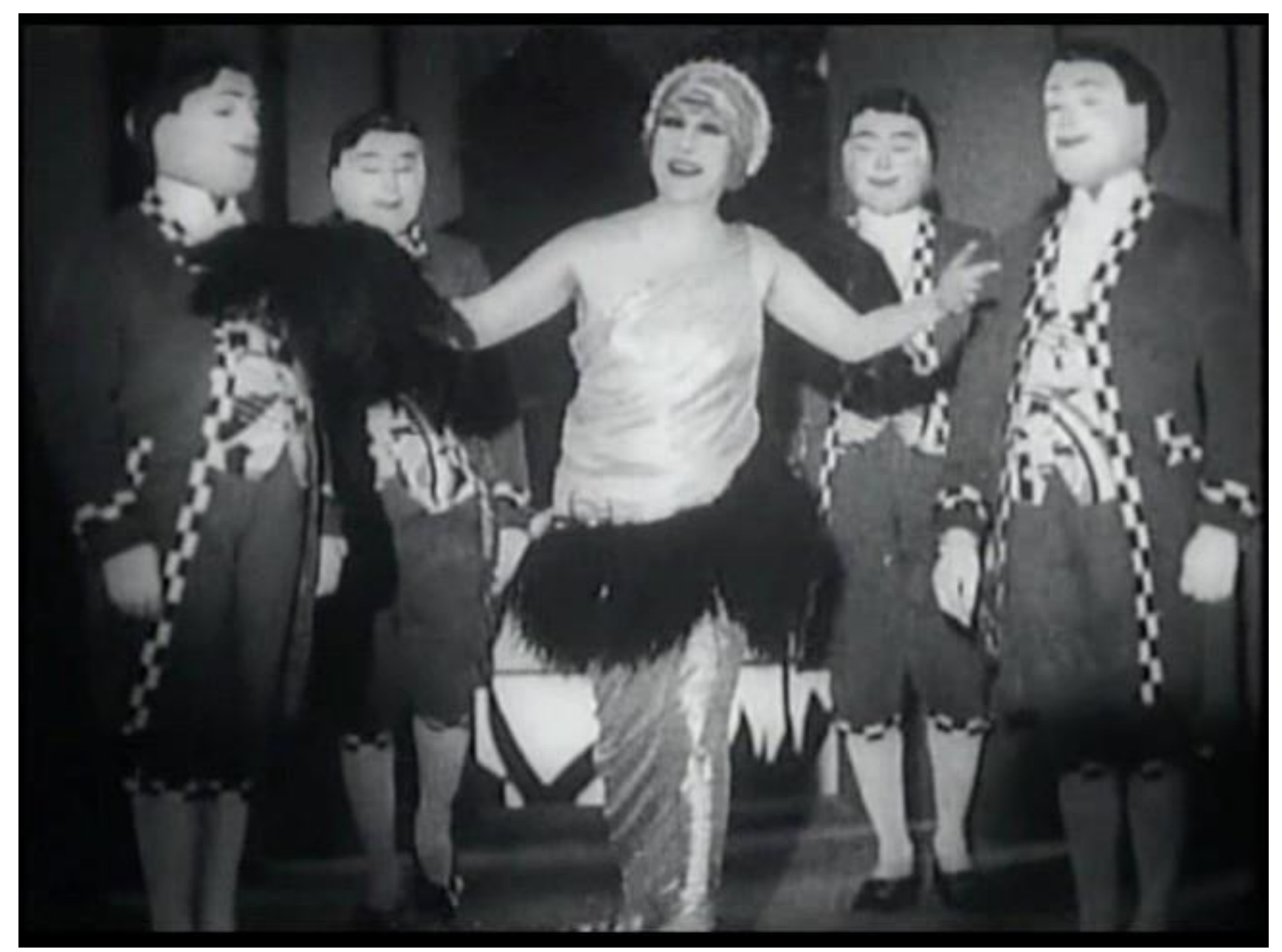

Figure 11: Claire and Servants

Claire Lescot, surrounded by her masked servants

Still from L'Inhumaine 

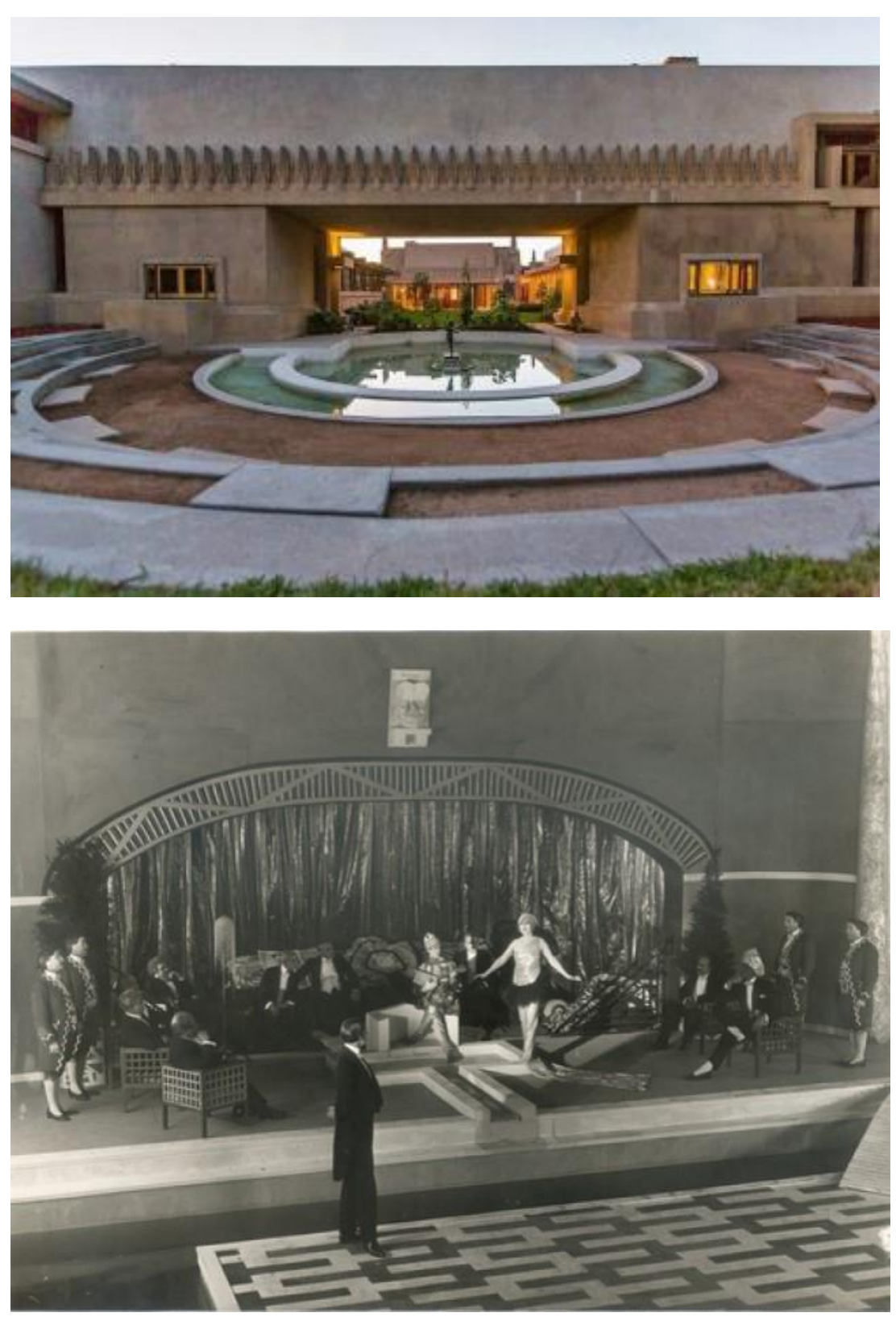

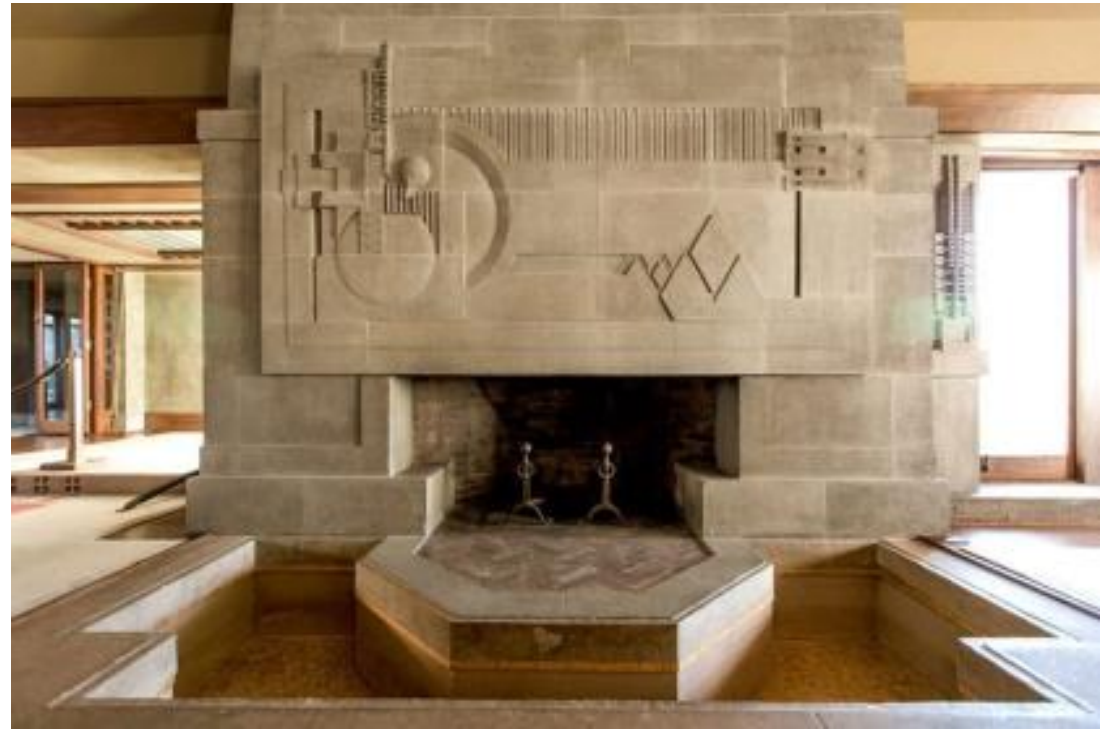

Upper Left and Right: Barnsdall House, Frank Lloyd Wright, 1919

Left: Exterior performance space

Right: Interior hearth with Art deco bas relief and surrounding fountain

Bottom Left:Claire Entertaining Suitors in Home

Set, Claude Autant-Lara

L'Inhumaine, 1924

Figure 12: Barnsdall House, in comparison to Lescot's performance 


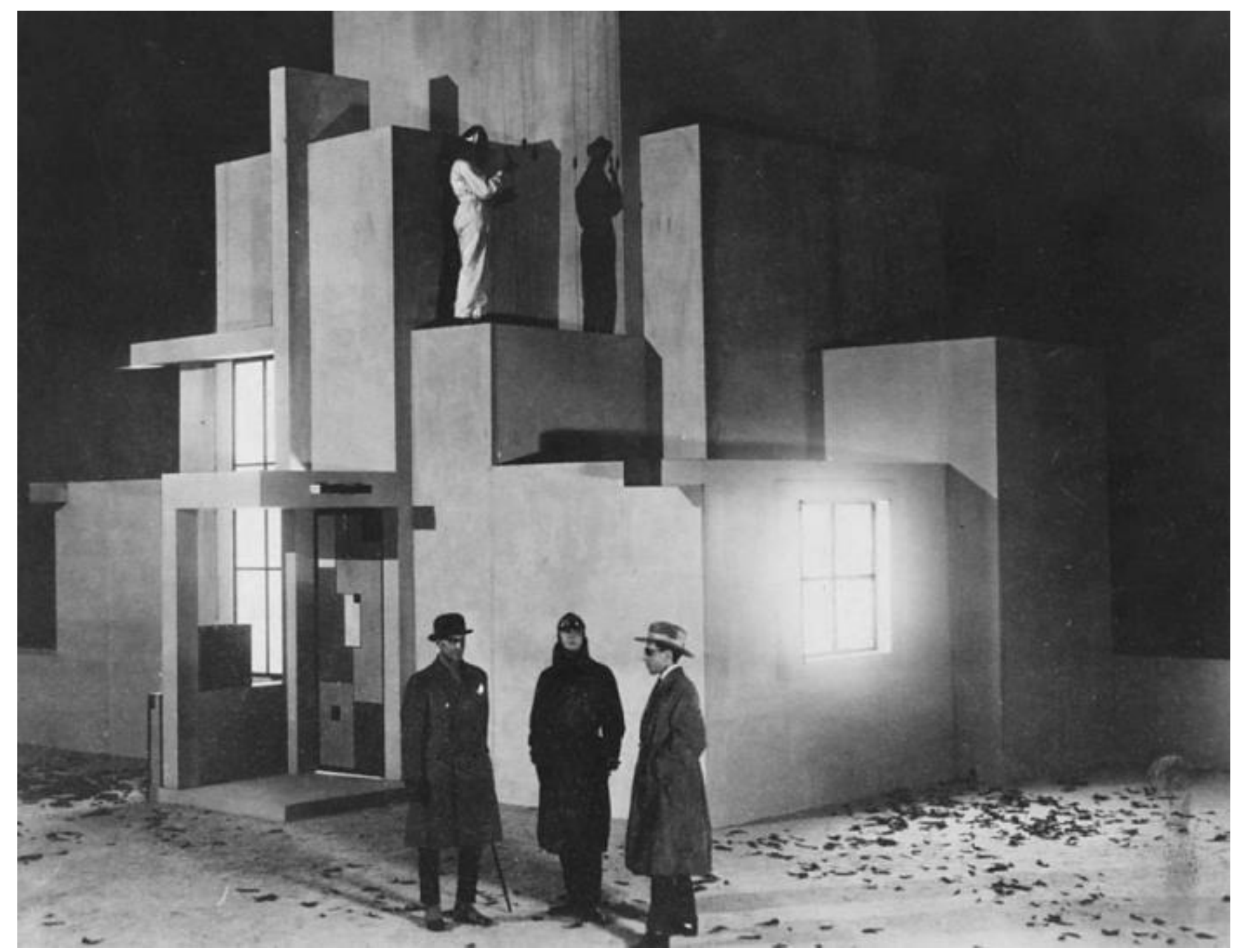

Photograph of Marcel L'Herbier, and MalletStevens, in front of Model of Einar's

House,

L'Inhumaine, 1924

Features very large

tower, that uses a

few seconds to pan up to reveal the scale See also: Tourism

Pavilion and Une

Cité Moderne

examples to see this trend

Figure 15: Einar Norsen's House 

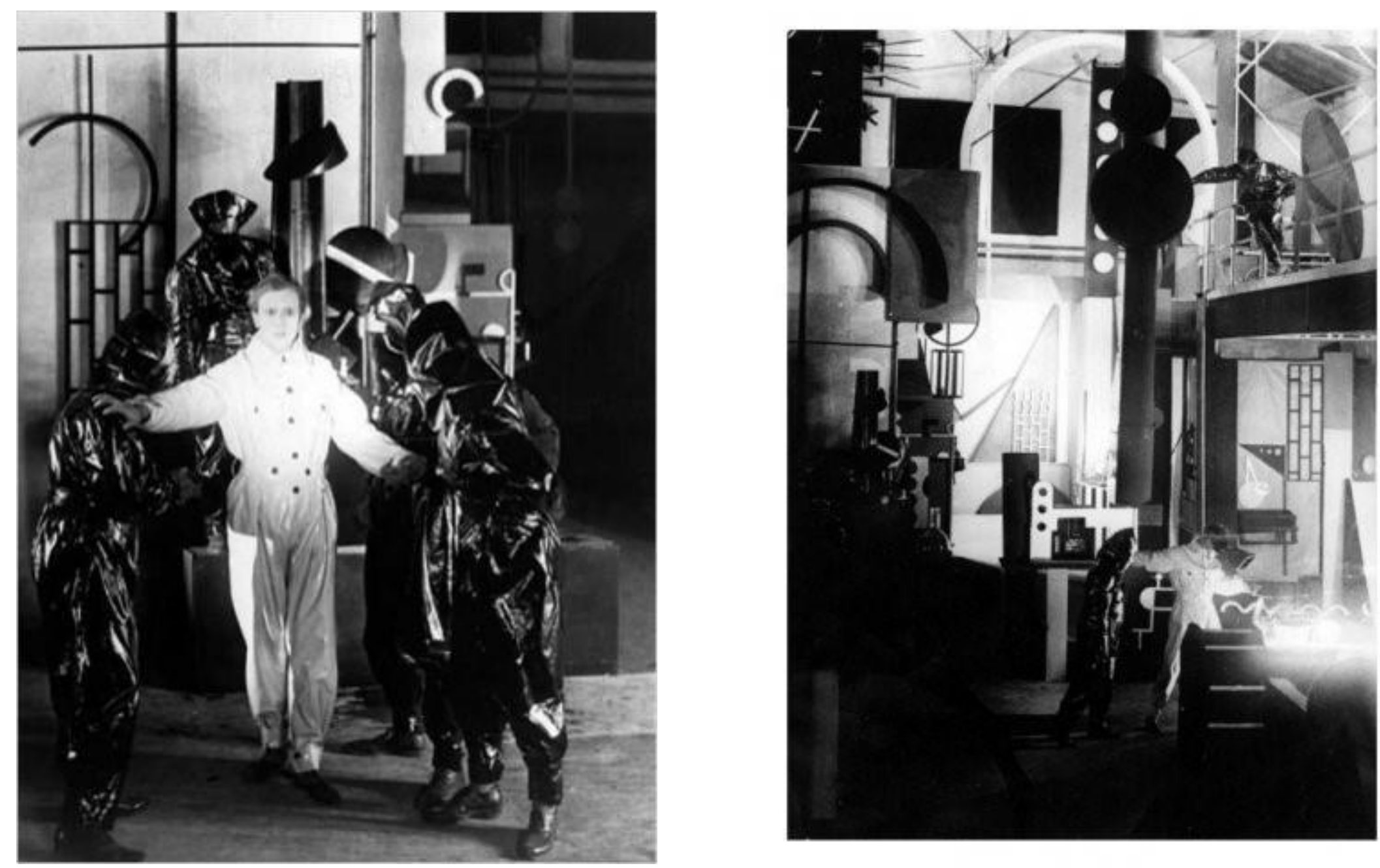

Figure 16: Einar Norsen's Laboratory

Einar's Laboratory, Designed by Fernand Leger L'Inhumaine, 1924

Right: Einar, played by Jaque Catelain, in Laboratory, surrounded by other "scientists" 


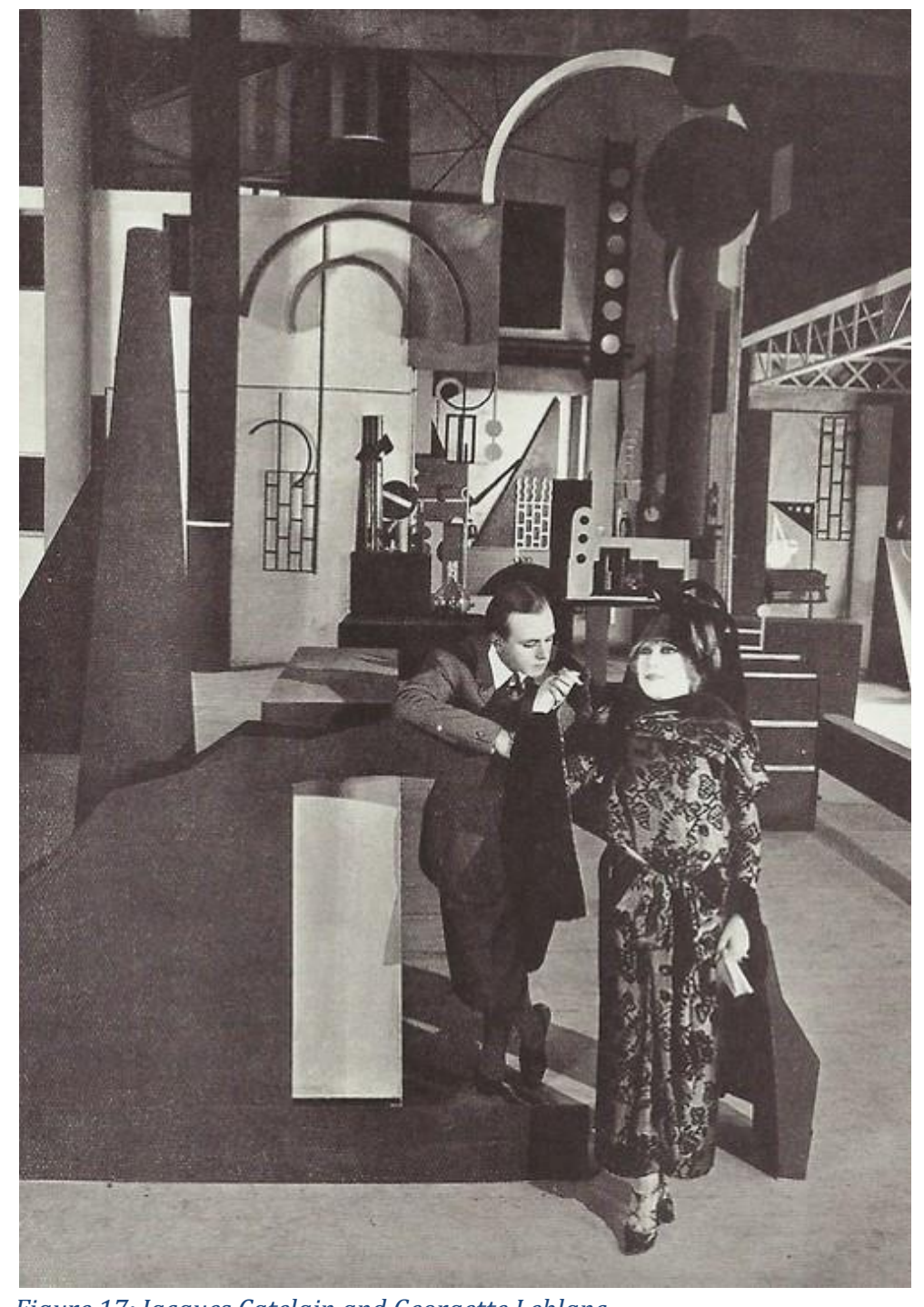

Figure 17: Jacques Catelain and Georgette Leblanc

Jaque Catelain and Georgette Leblanc as Einar Norsen and Claire Lescot in Einar's Laboratory Still, L'Inhumaine, 1924 


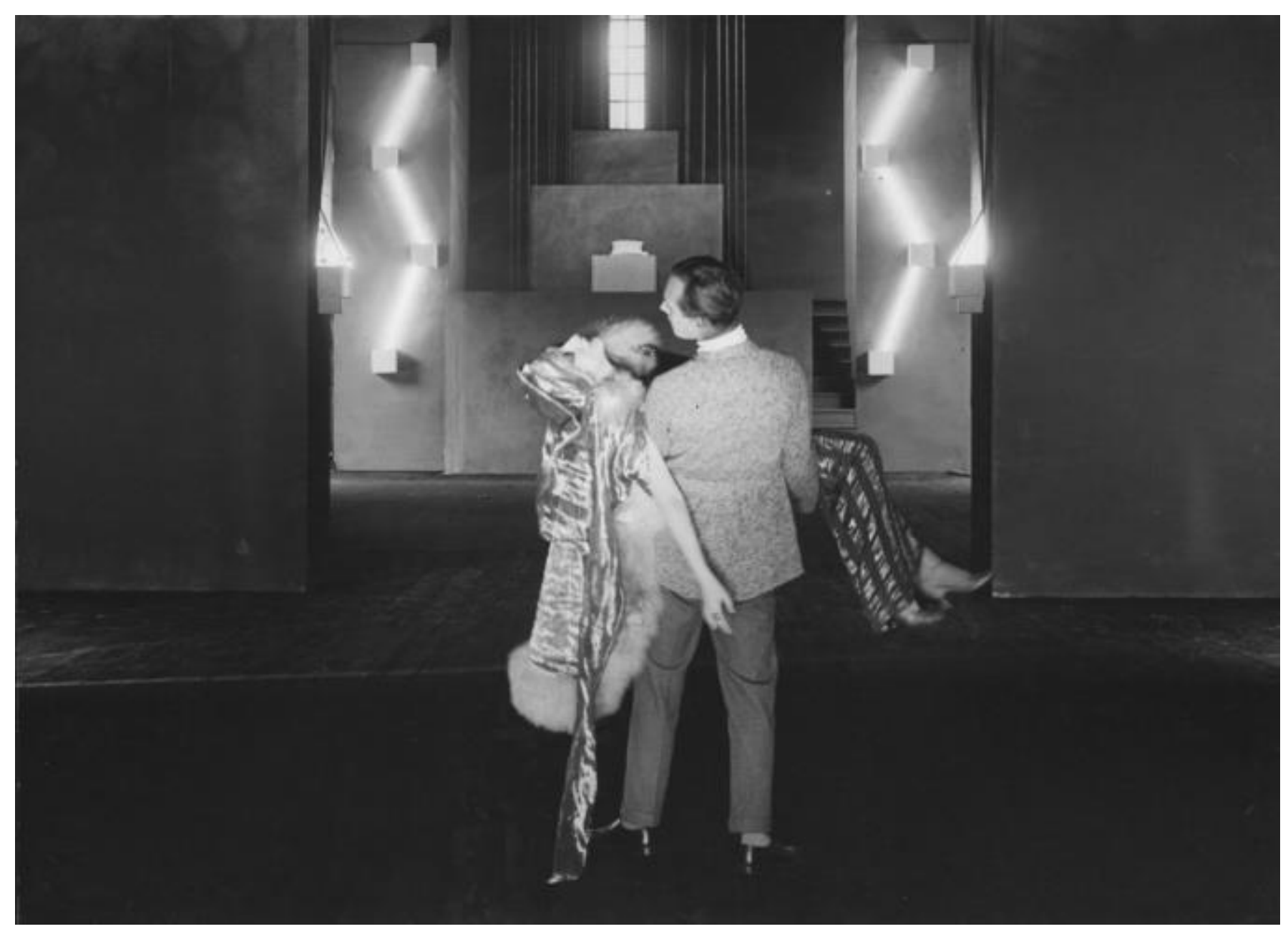

Figure 18: Finale

Einar and Claire in "laboratory" to bring Claire back to life with Science, Finale Still, L'Inhumaine, 1924 


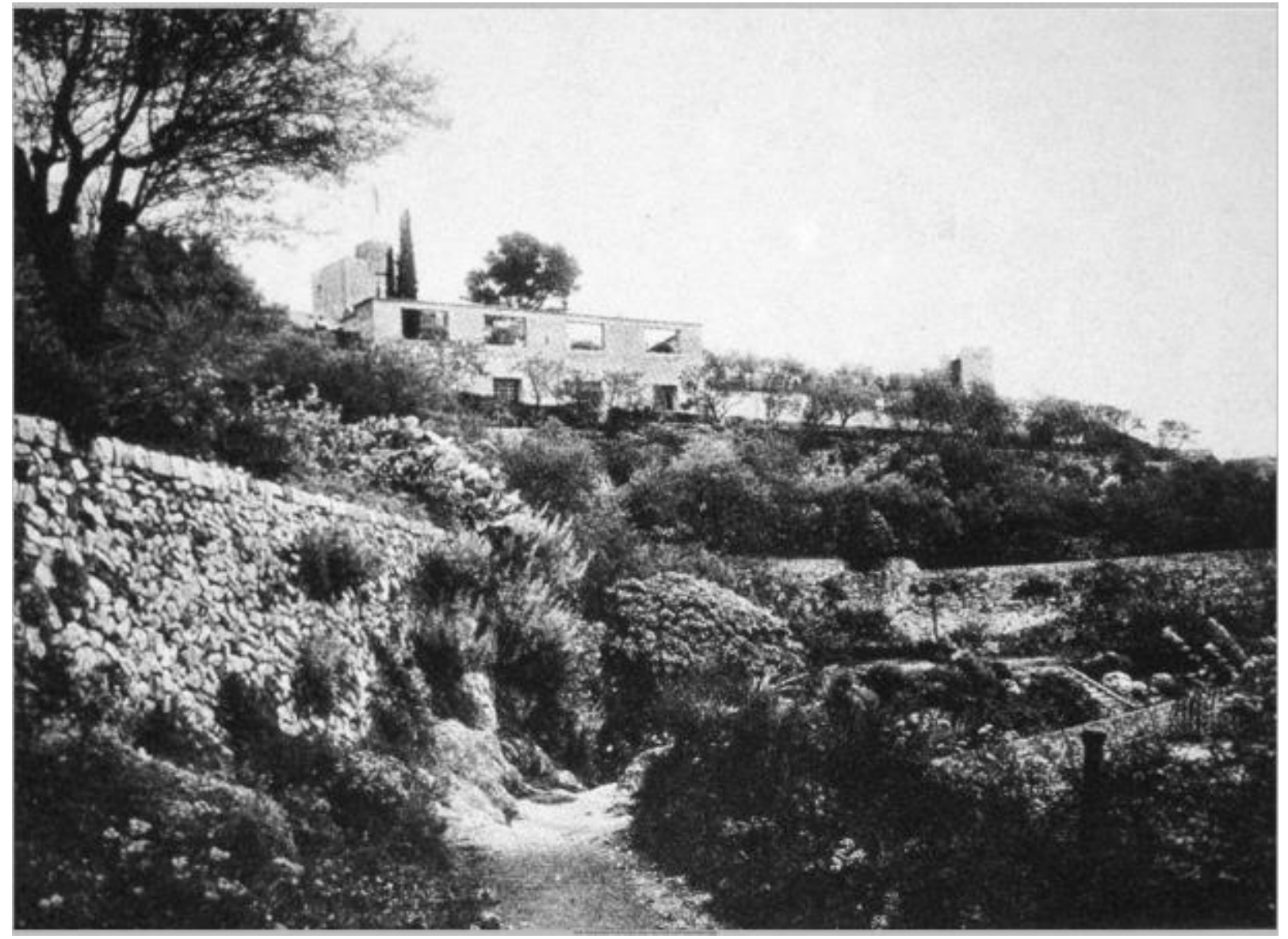

Figure 19: Villa Noailles Exterior

Historic View of Villa Noailles from Parc St. Bernard, 


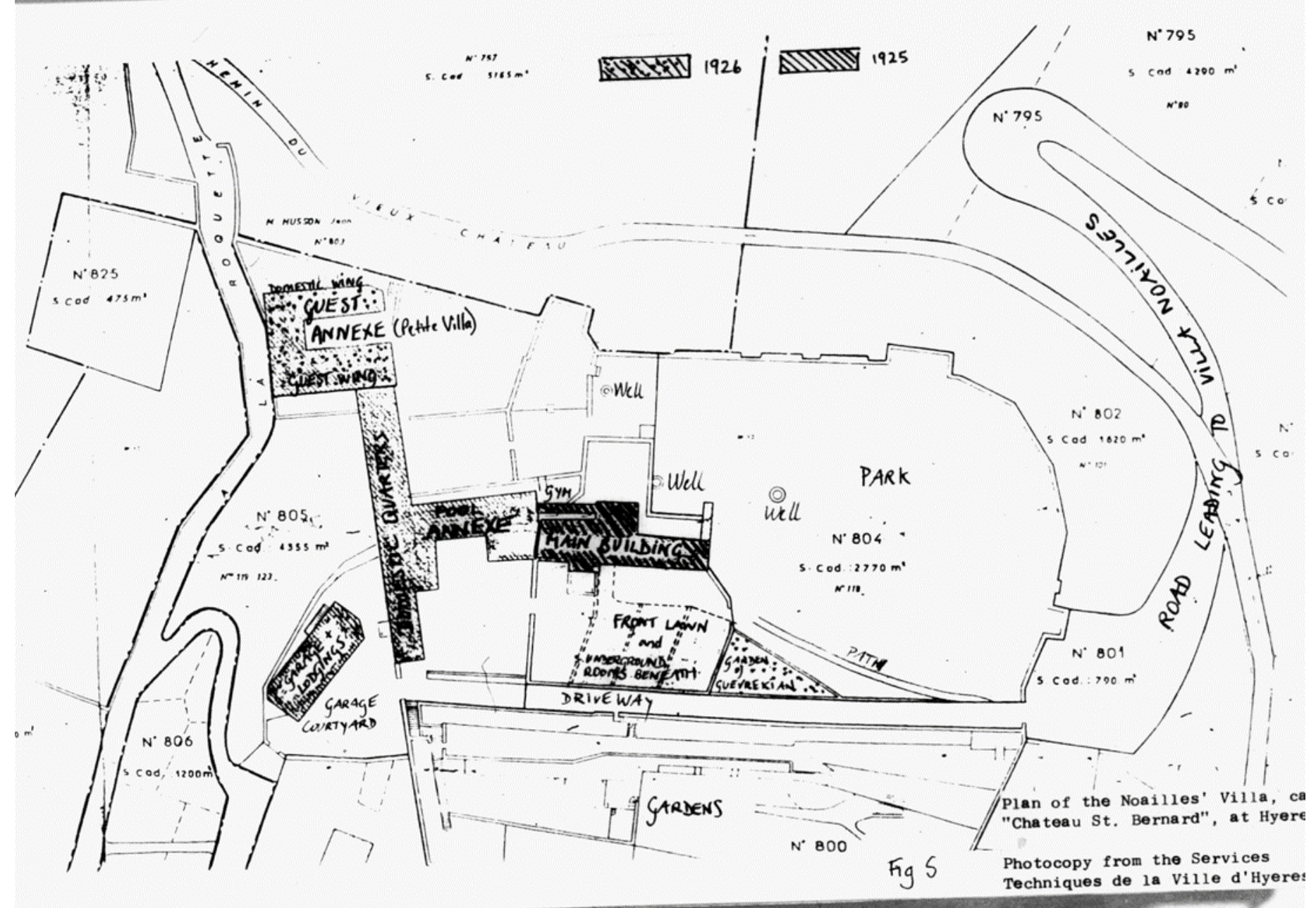

Figure 20: Villa Noailles Site Plan

Villa Noailles, Site Plan, Shane Marie Dunworth, Dissertation, 1985 


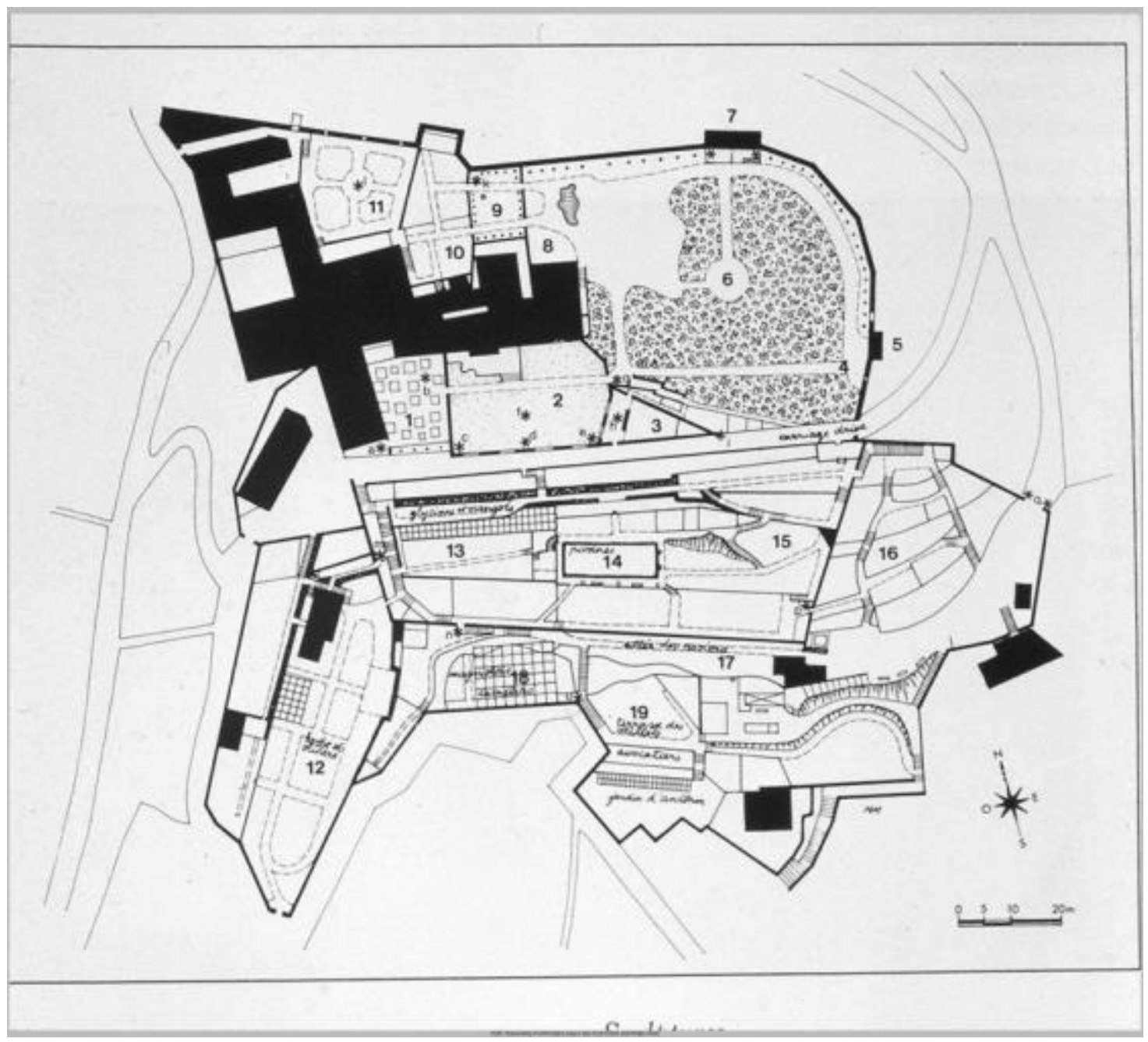

Figure 21: Villa Noailles, Landscape Diagram

Site plan of Landscape Architecture, Villa Noailles, Shane Marie Dunworth, Dissertation, 1985 


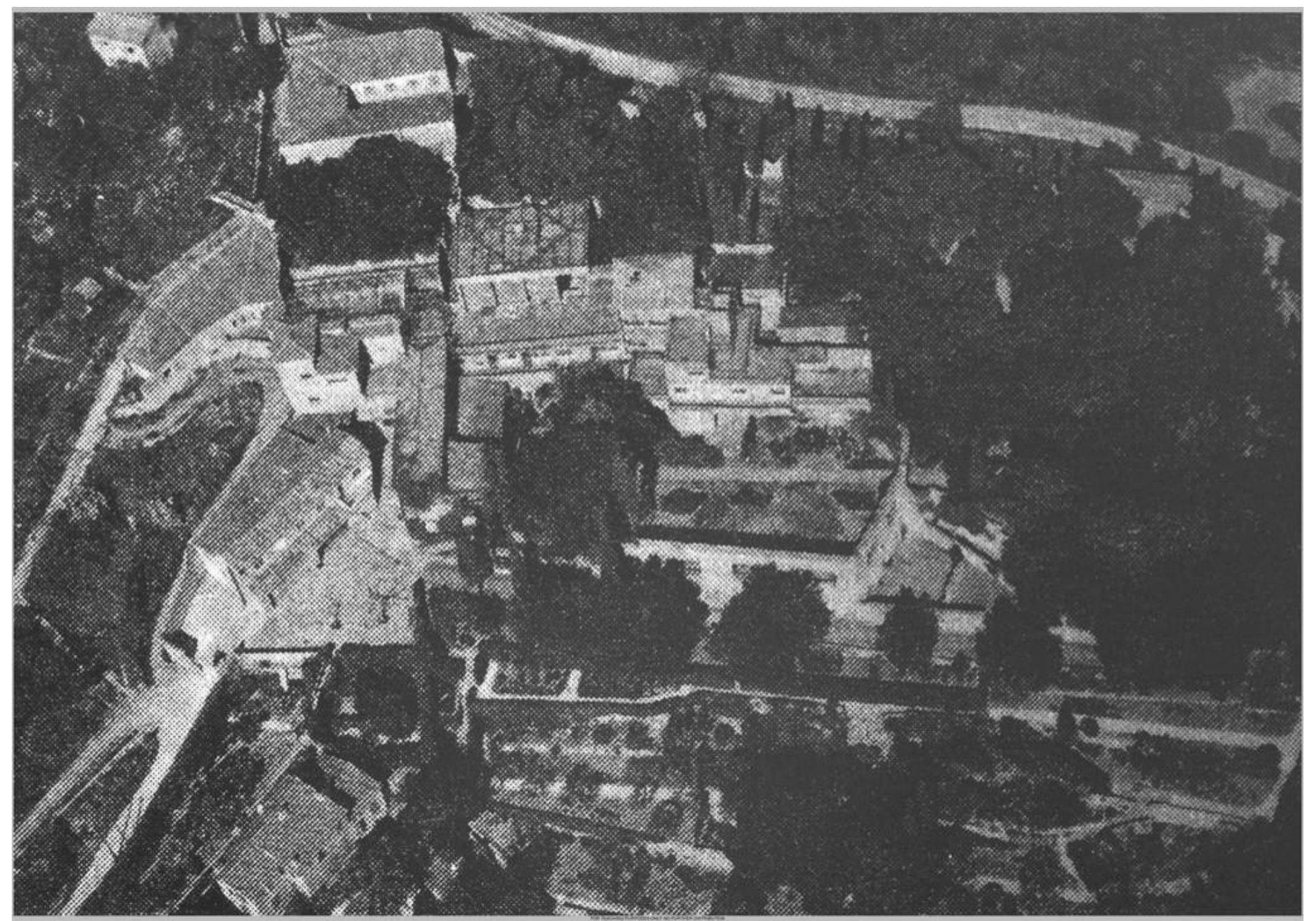

Figure 22: Villa Noailles, Aerial Photo

Villa Noailles, Historic site Photo 


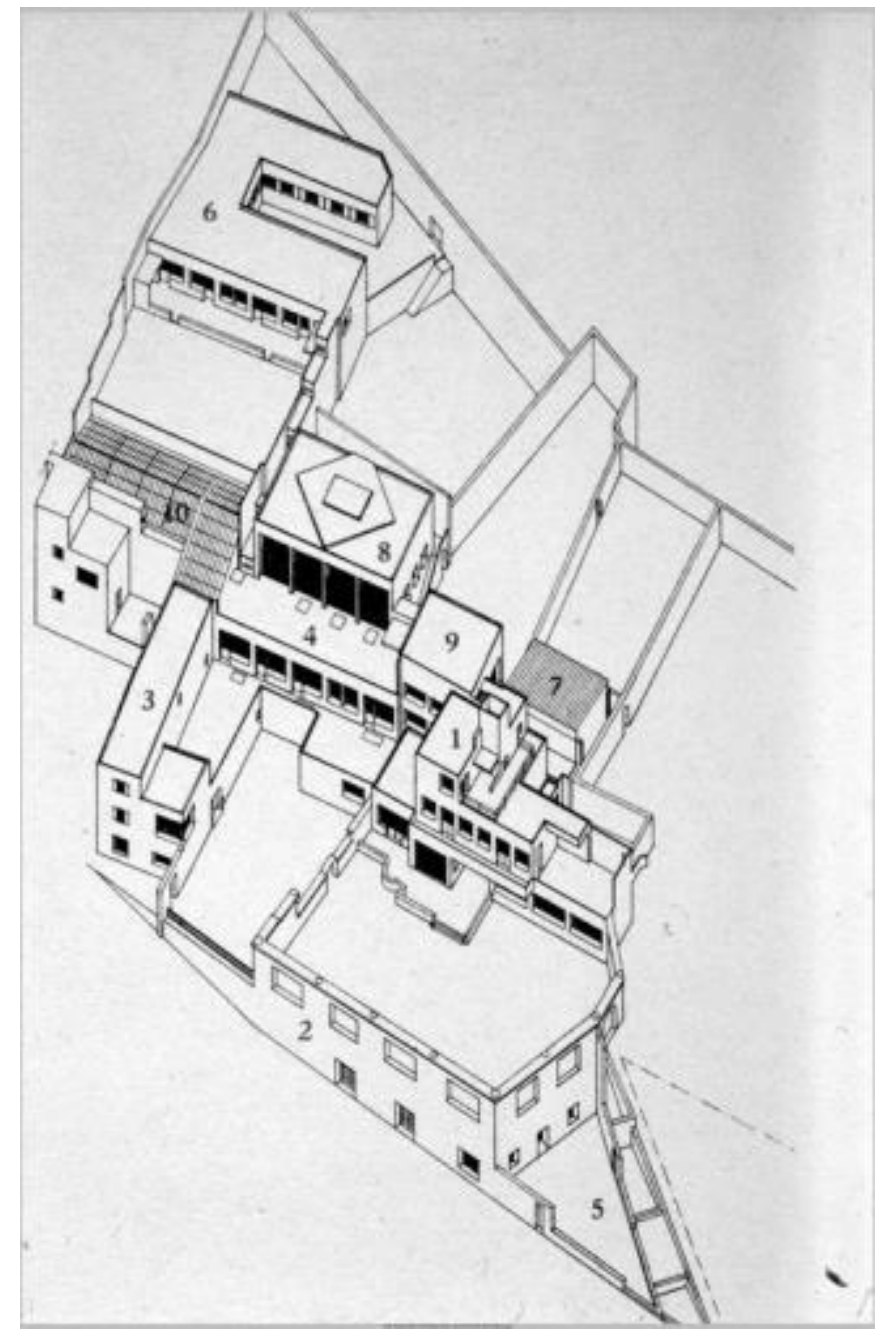

Figure 23: Villa Noailles Axon

Villa Noailles, axonometric site plan 


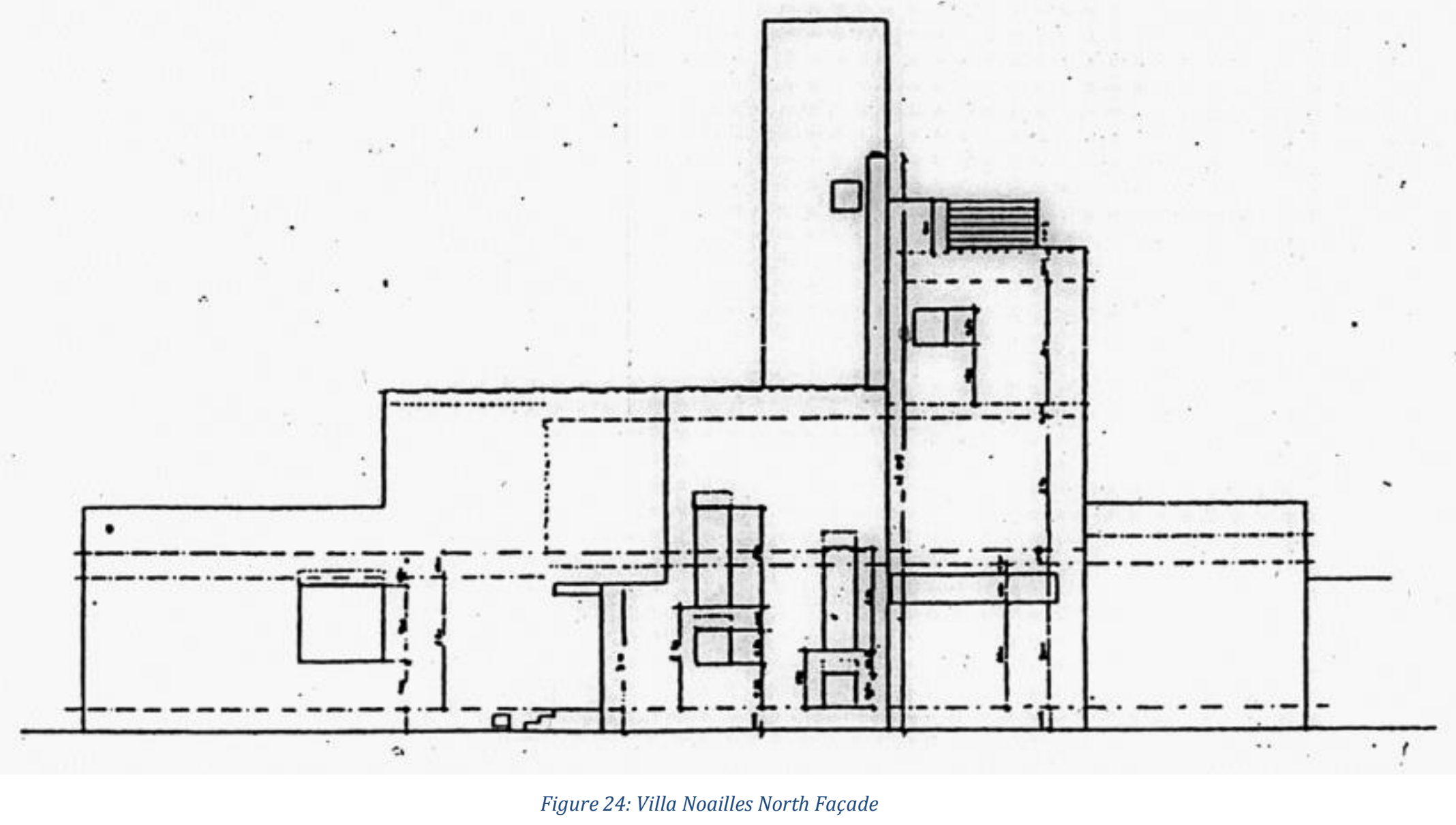

Villa Noailles, 1924 Elevation of North Side, Shane Marie Dunworth Dissertation, 1985 


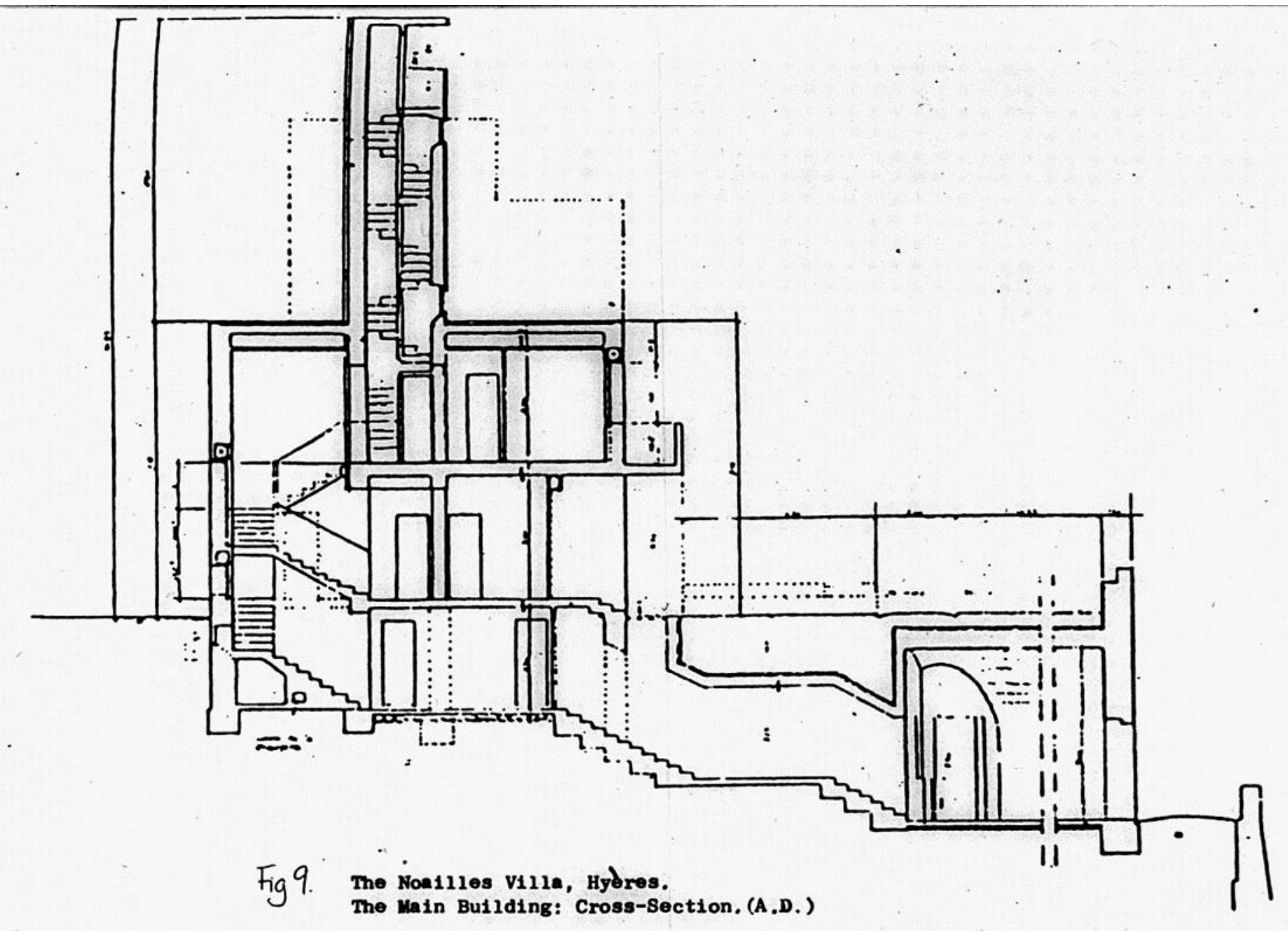

Figure 25: Villa Noailles Section

Villa Noailles, Main Building, Cross-Section, 1924, Shane Marie Dunworth Dissertation, 1985 


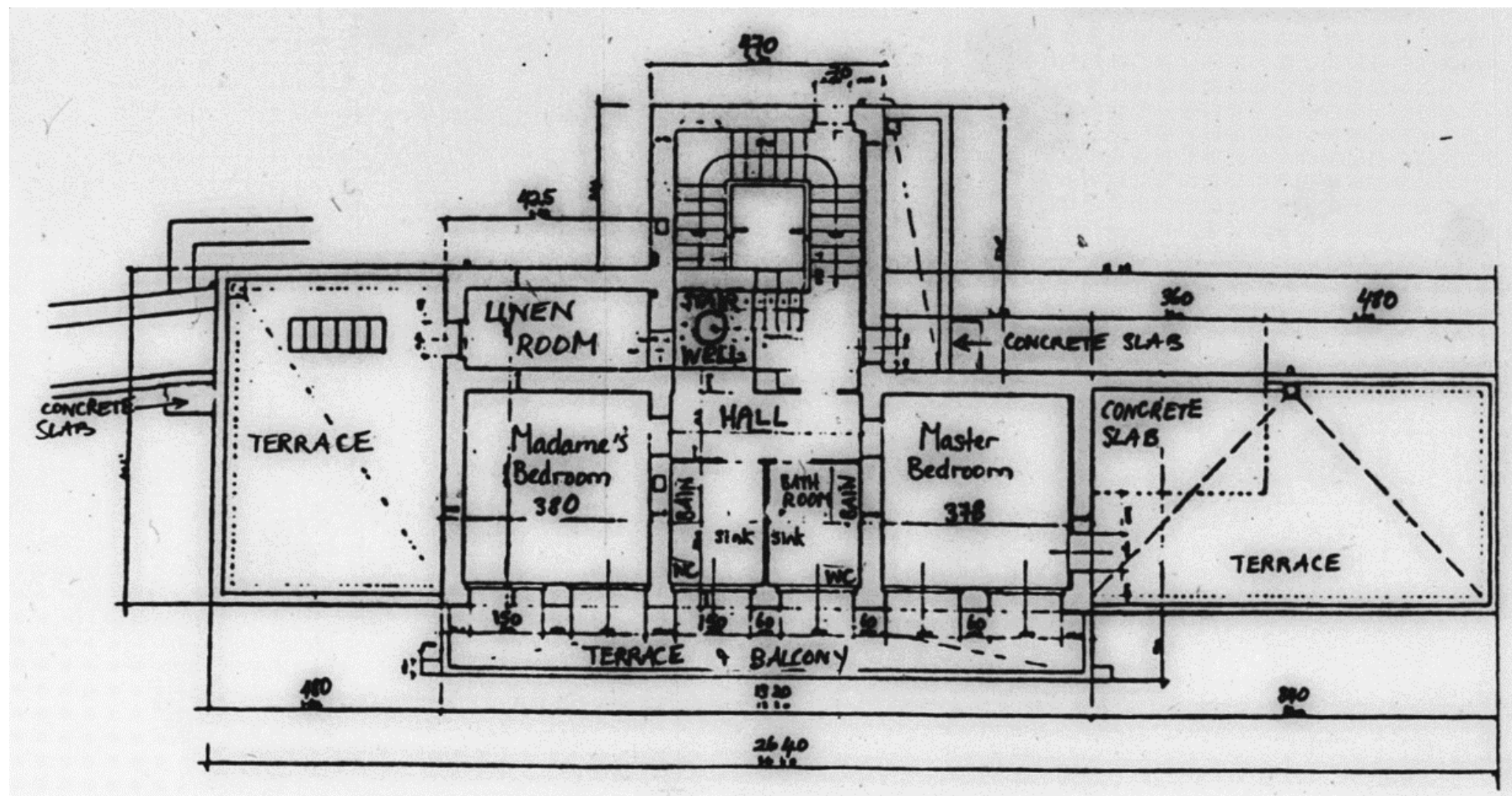

Figure 26: Villa Noailles Plan

$$
\begin{aligned}
& \text { The Noallles Villa } \\
& \text { Plan, of the Ist Floor, I924 }
\end{aligned}
$$

Villa Noailles, Plan of Second Floor, 1924, Shane Marie Dunworth Dissertation, 1985 


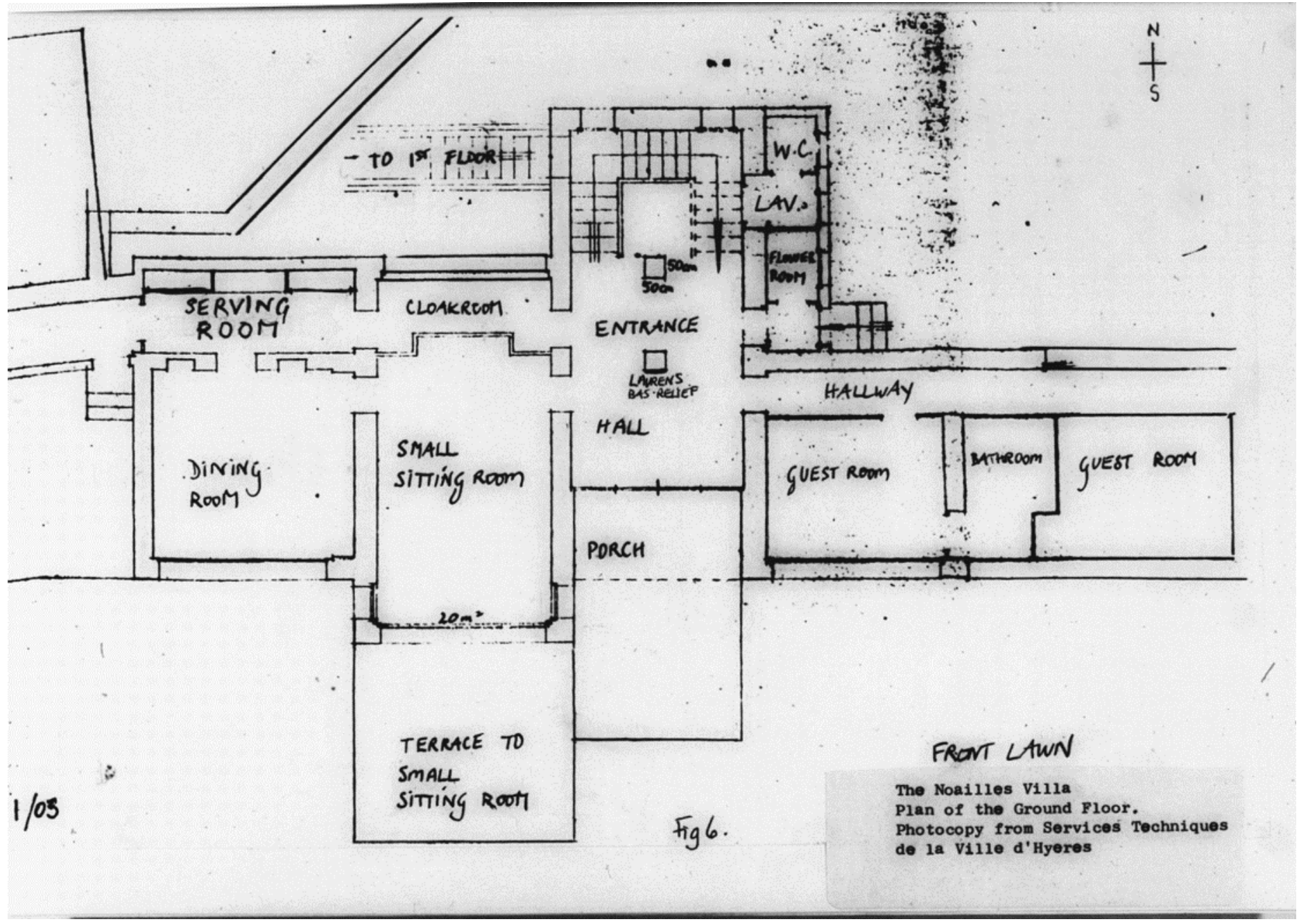

Figure 27: Villa Noailles Plan

Villa Noailles, Plan of Ground Floor, ca. 1924, Shane Marie Dunworth Dissertation, 1985 


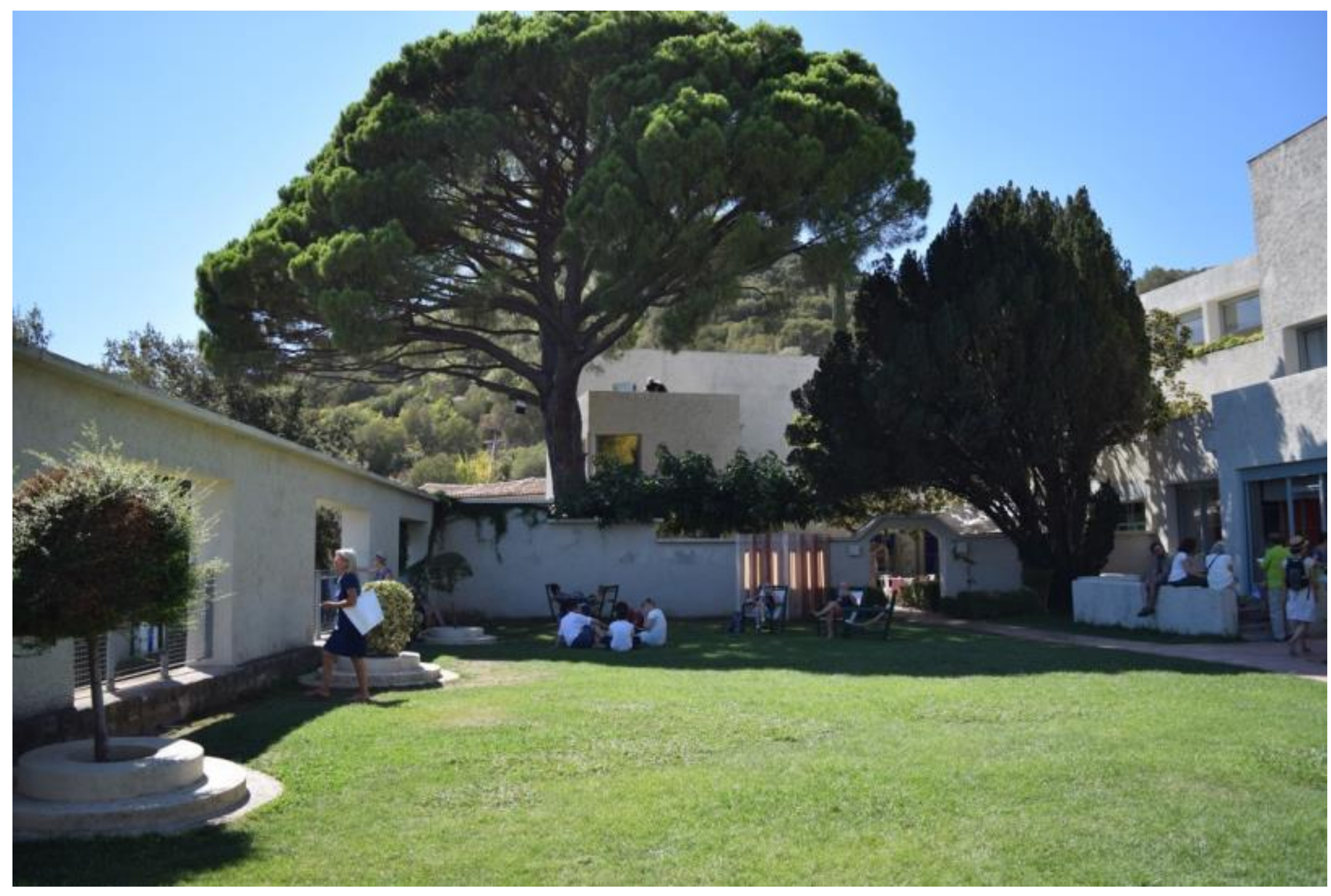

Figure 28: Villa Noailles Lawn

Villa Noailles, Front Lawn with Cloister Walls, Photo: Author's Own, August 2016 


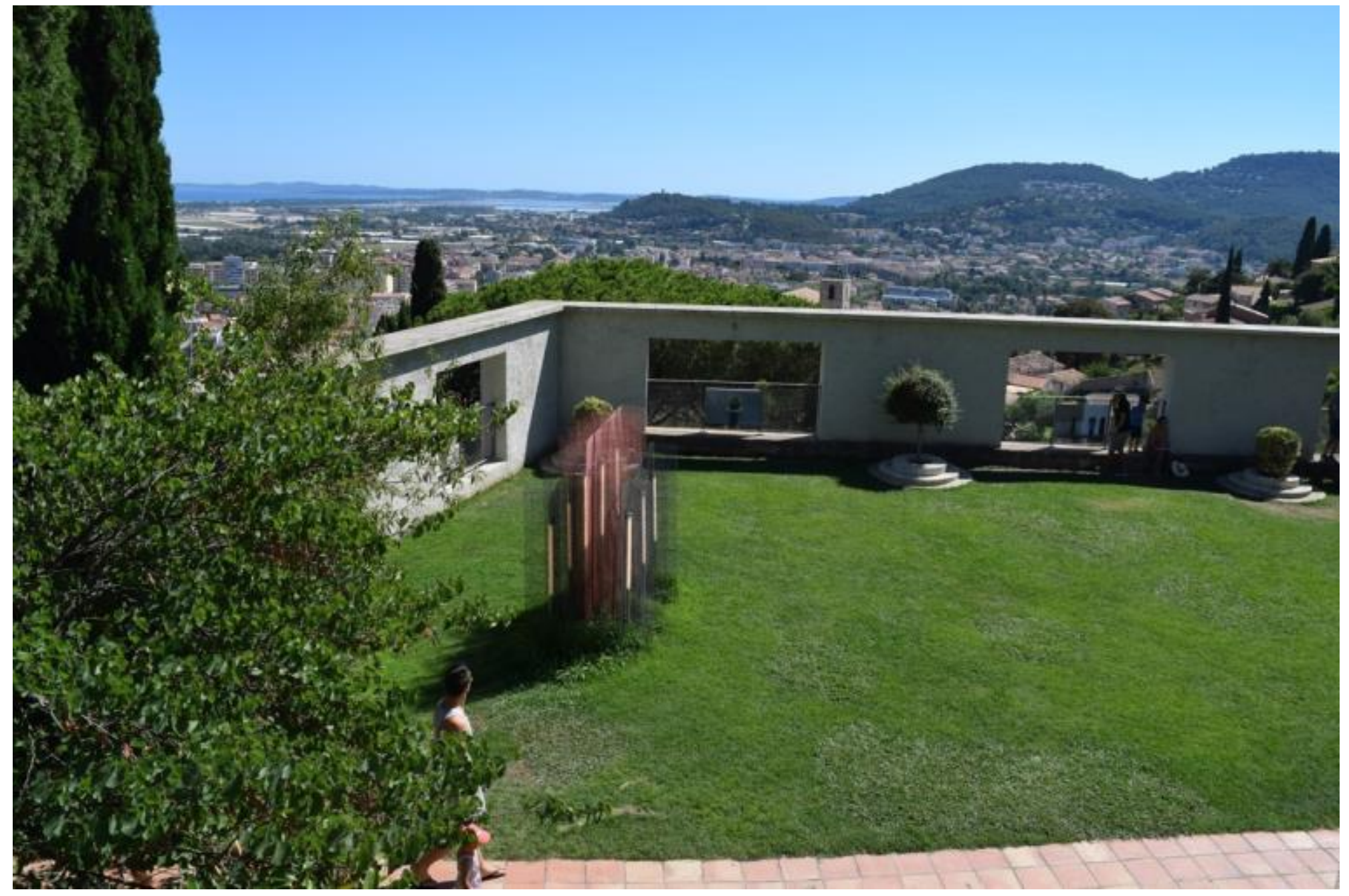

Figure 29 Villa Noailles Lawn

Villa Noailles, View of Town and Lawn from Outdoor Bedroom Terrace, Photo: Author's Own, August 2016 


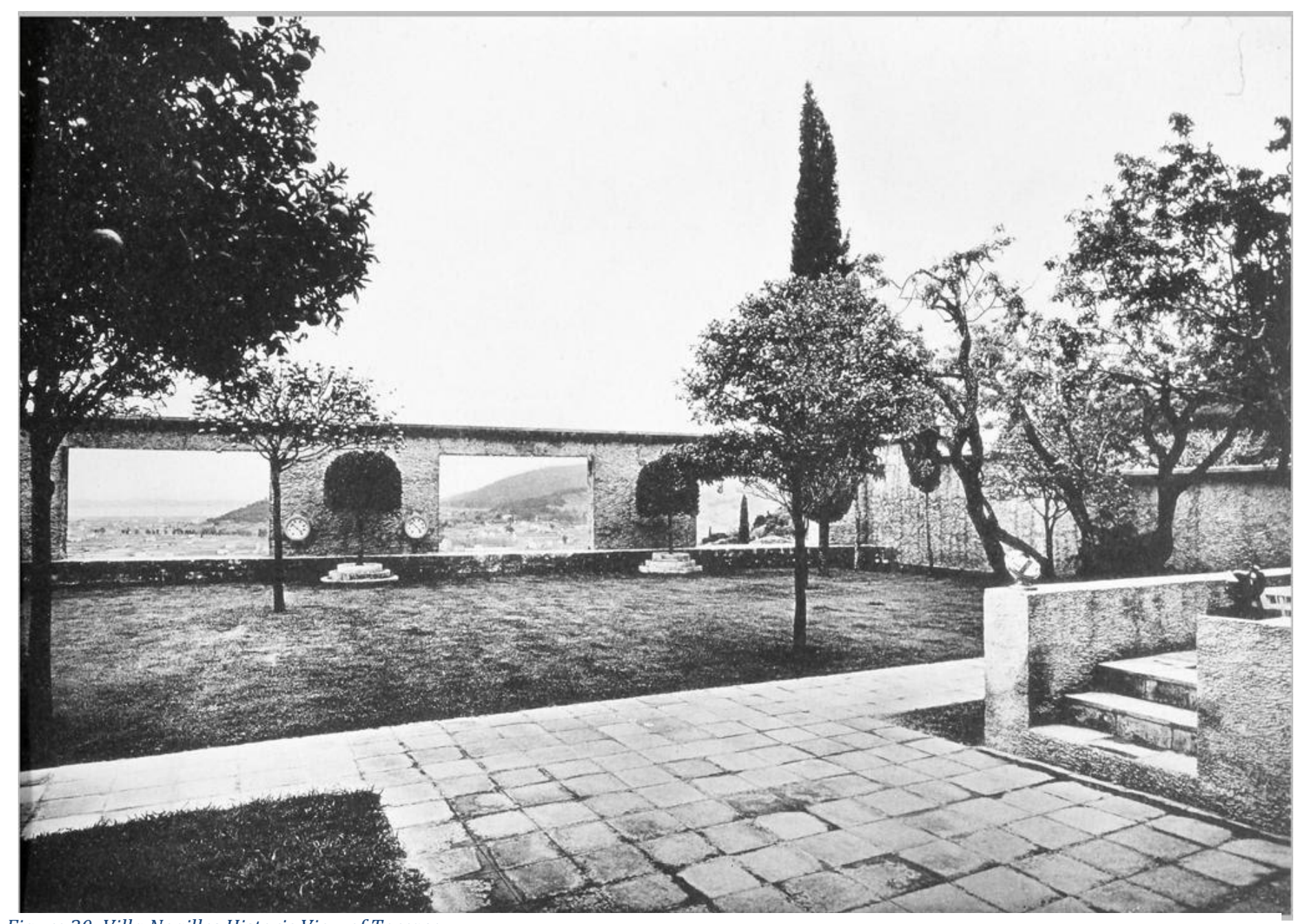

Figure 30: Villa Noailles Historic View of Terrace

Historic View of Terrace 


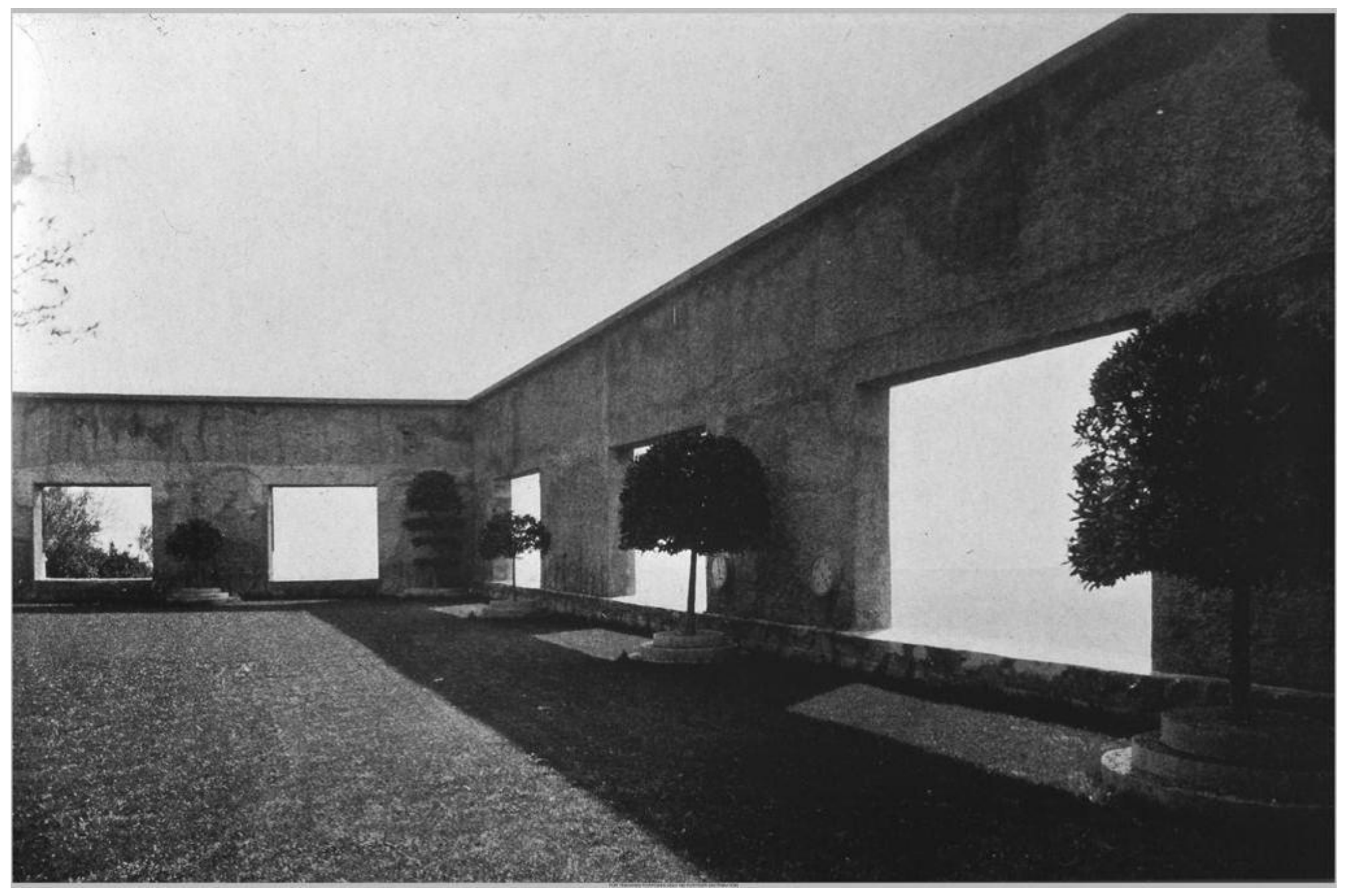

Figure 31: Historic View of Terrace

Historic photo of terrace, traces of photo-editing 


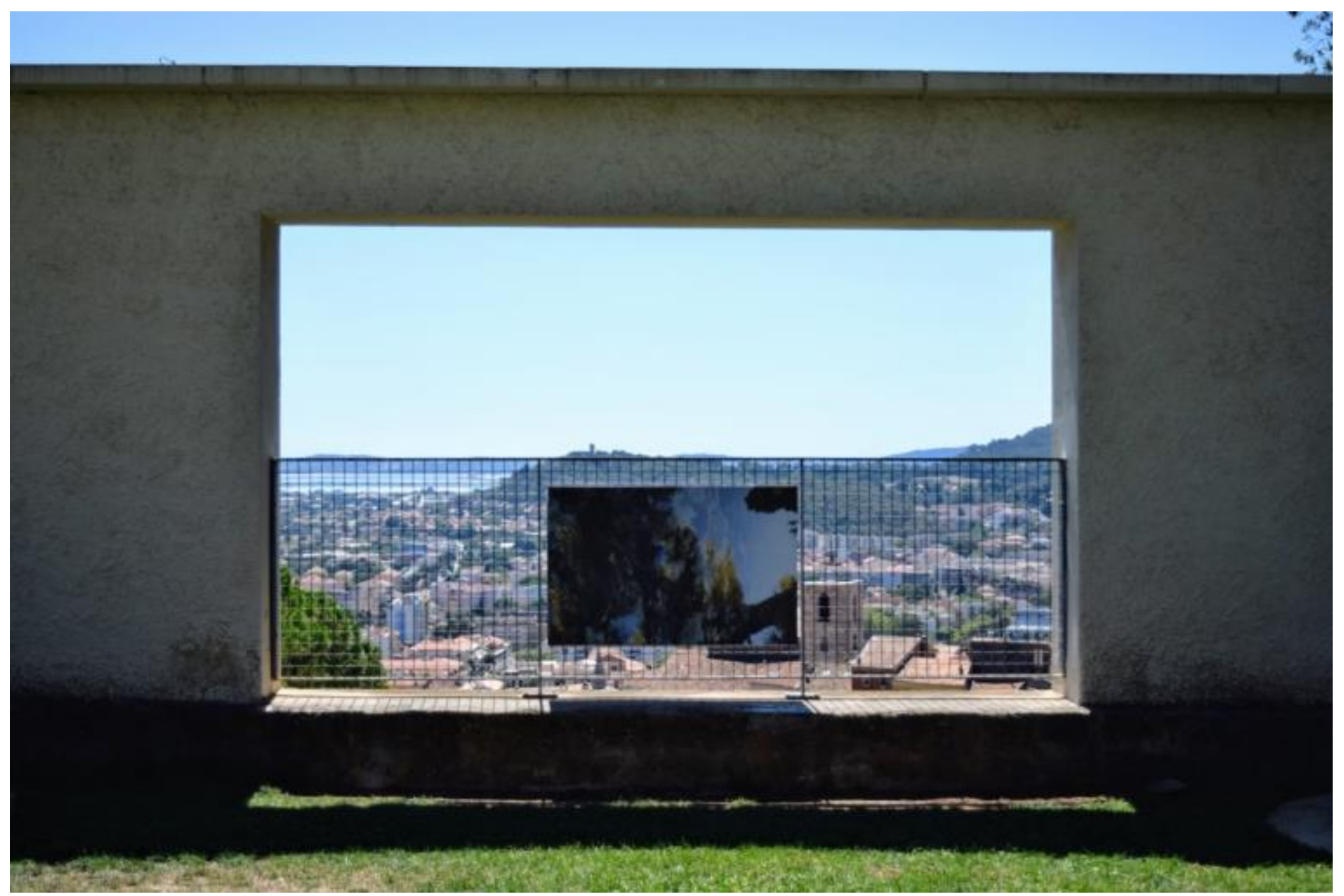

Figure 32: Villa Noailles Wall Cut out

View of "Cloister wall" from Front Lawn of Villa Noailles

Photo: Author's Own, August 2016 


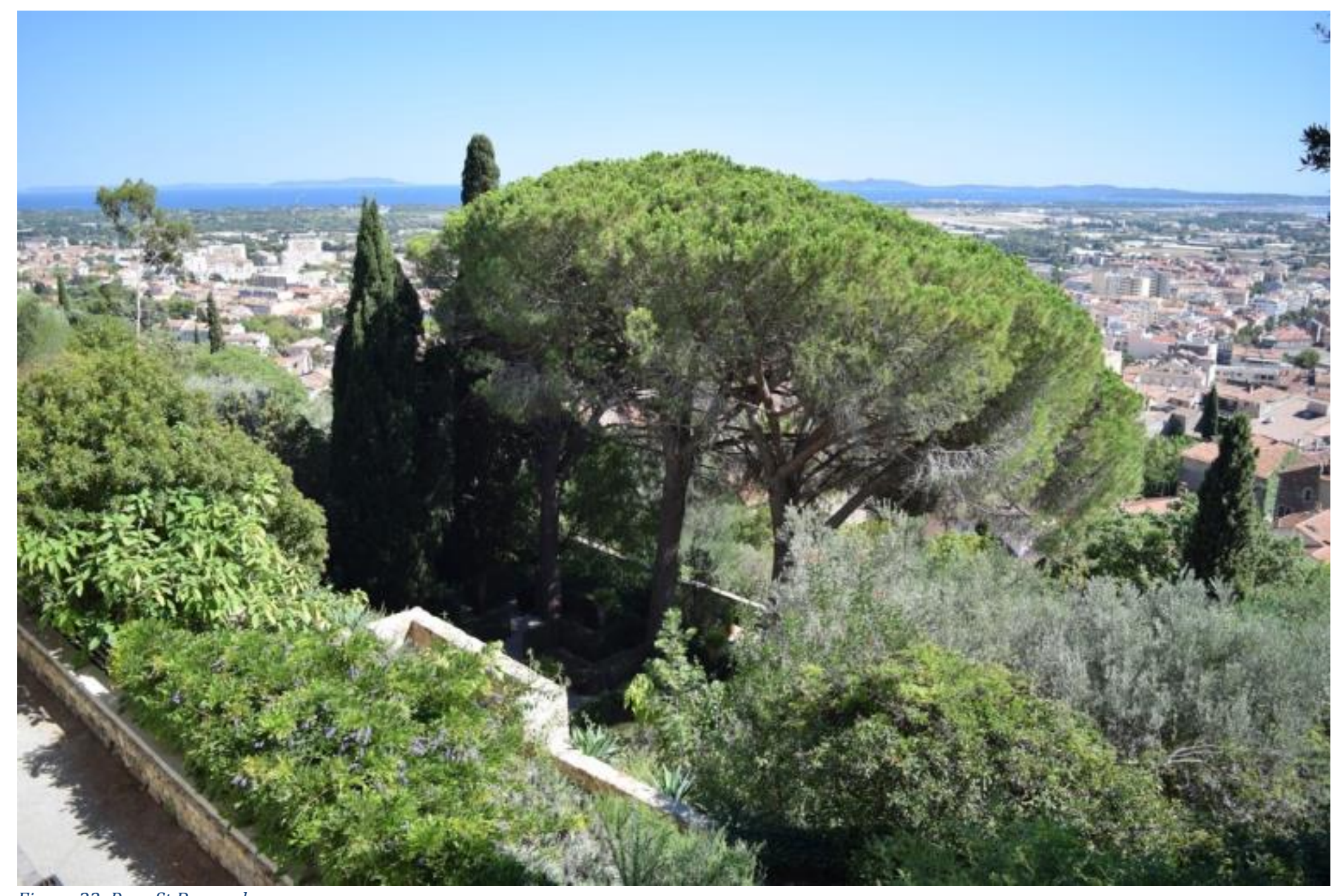

Figure 33: Parc St Bernard

View of Parc St. Bernard (established by Charles de Noailles) from Villa Noailles Photo: Author's Own, August 2016 


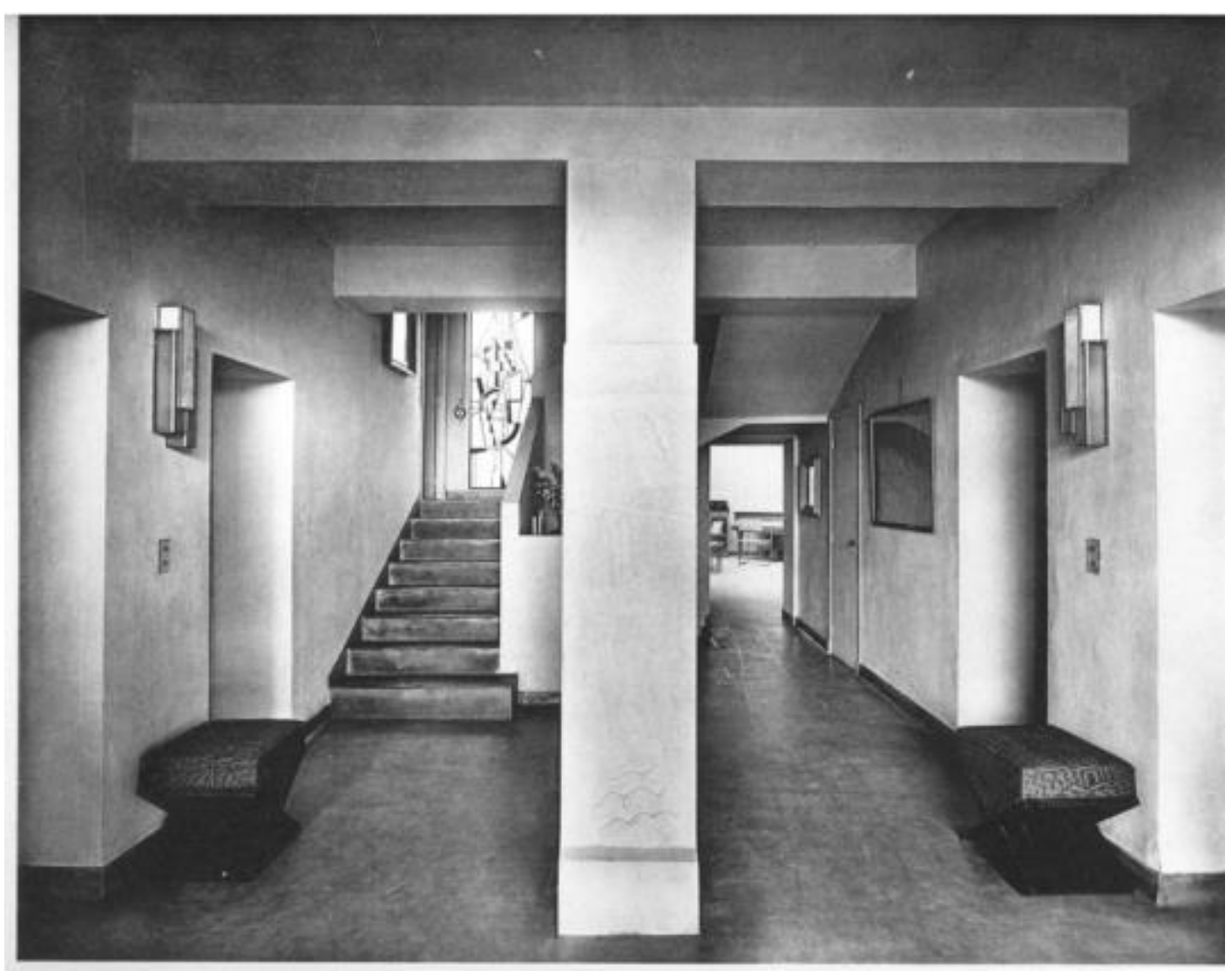

Figure 34: Entrance Hall

View of Entrance Hall, Villa Noailles, Thérèse Bonney, 1928

Photograph by Thérèse Bonney

Dining room to the left, Salle de Fleurs to the right, and the room situated in the center-right was Charles' Study, also known as the Rose Room 


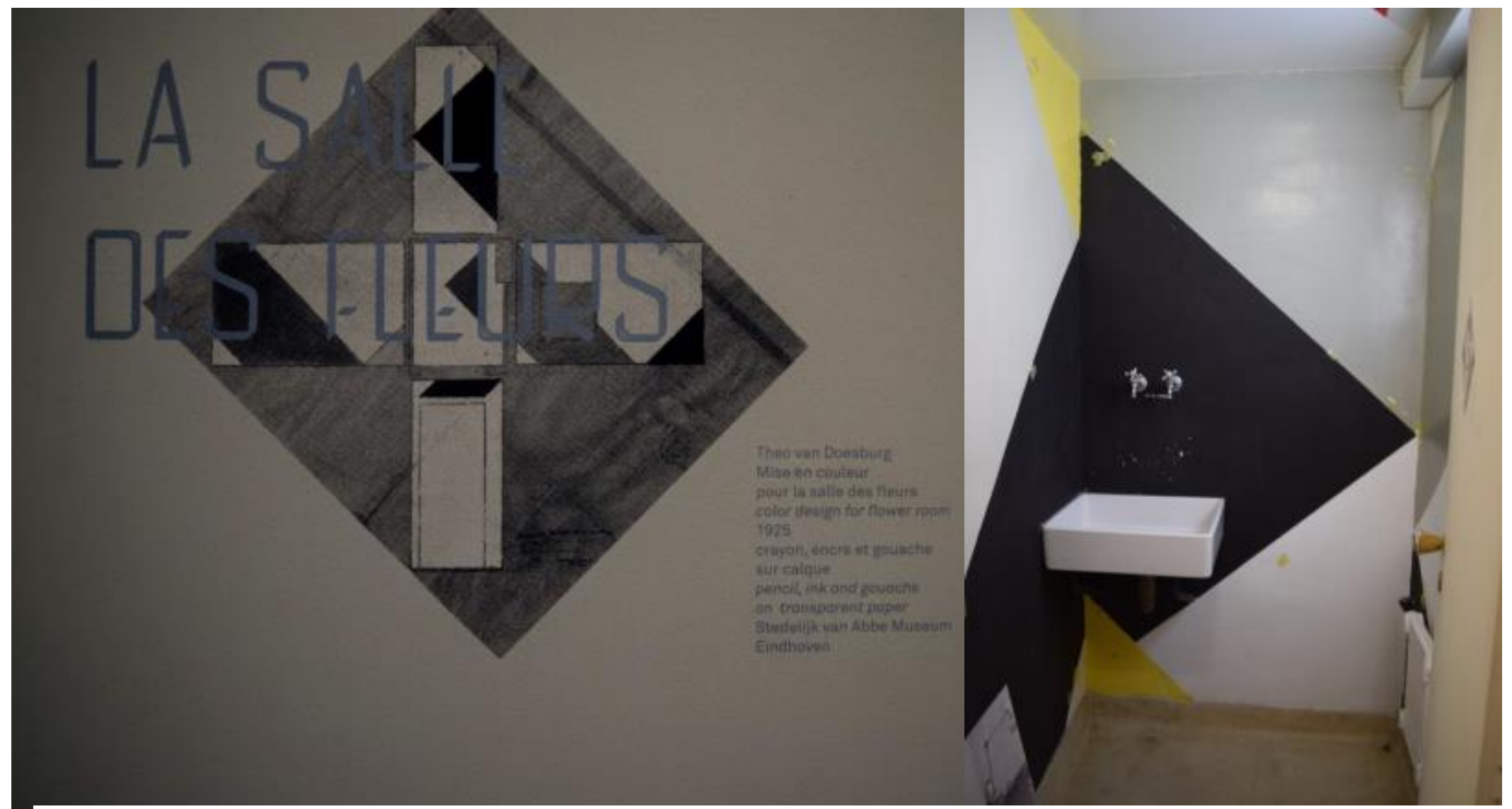

Figure 35: Salle de Fleurs

Villa Noailles, La Salle de Fleurs, for making flower arrangements, painted by Theo van Doesburg Photo: Author's Own, August 2016

Showed an attempt to flatten the space of the room by painting flat panes of color across different surfaces like walls and from wall to ceiling. 


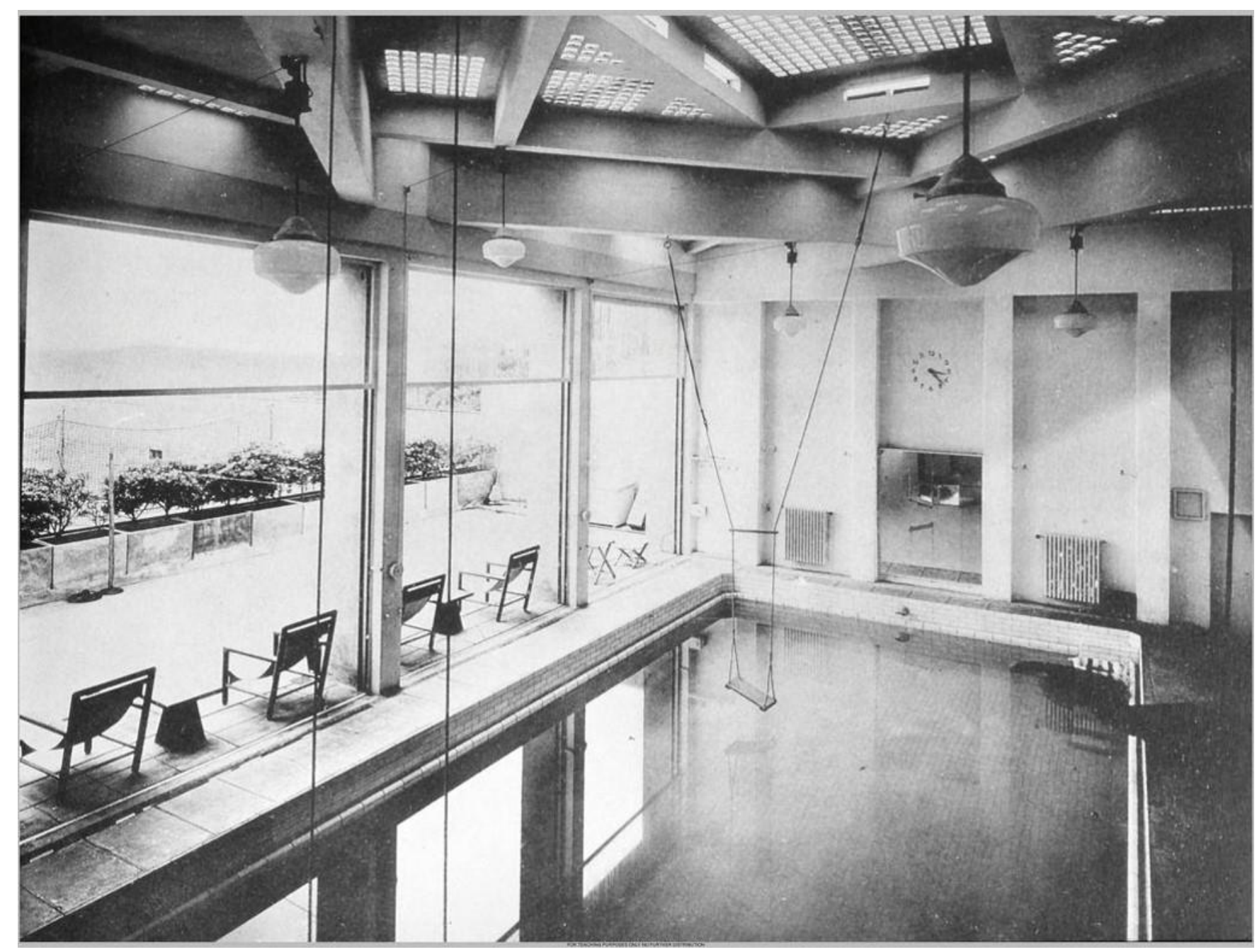

Figure 36: Swimming Pool

Villa Noailles, Pool, Photo by Thérèse Bonney, ca. 1928

Pool with Gymnastics Equipment. Notice Wall Clock by Jourdain, and Mallet-Stevens' designed tube and cloth recliners 


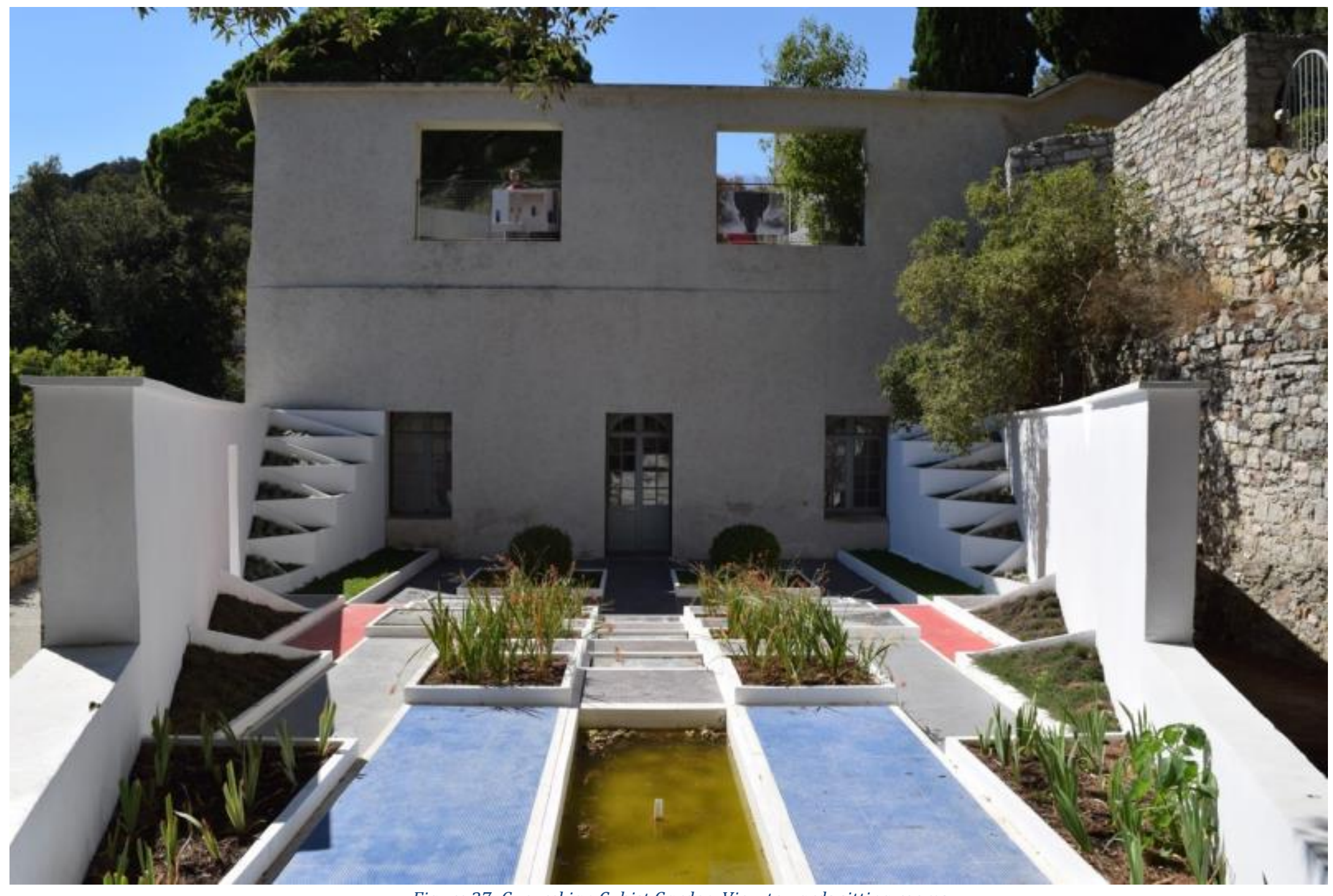

Figure 37: Guevrekian Cubist Garden, View towards sitting rooms

Guevrekian Garden, view to front Patio, and Basement Sitting Rooms Photo: Author's Own, August 2016 


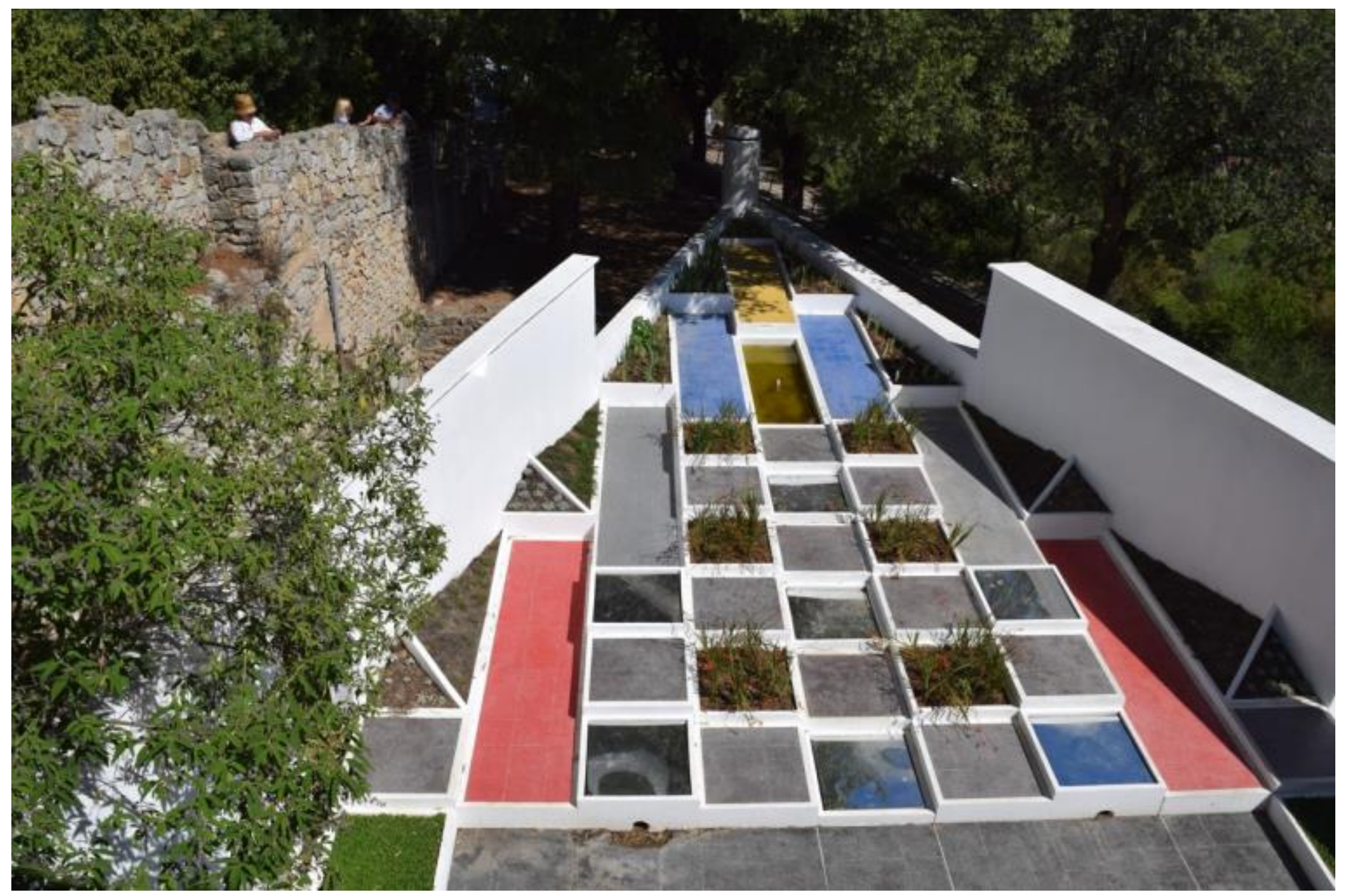

Figure 38: Garden II

Guevrekian cubist gardens, ca 1925, view from Front Lawn

Photo: Author's Own, August 2016 


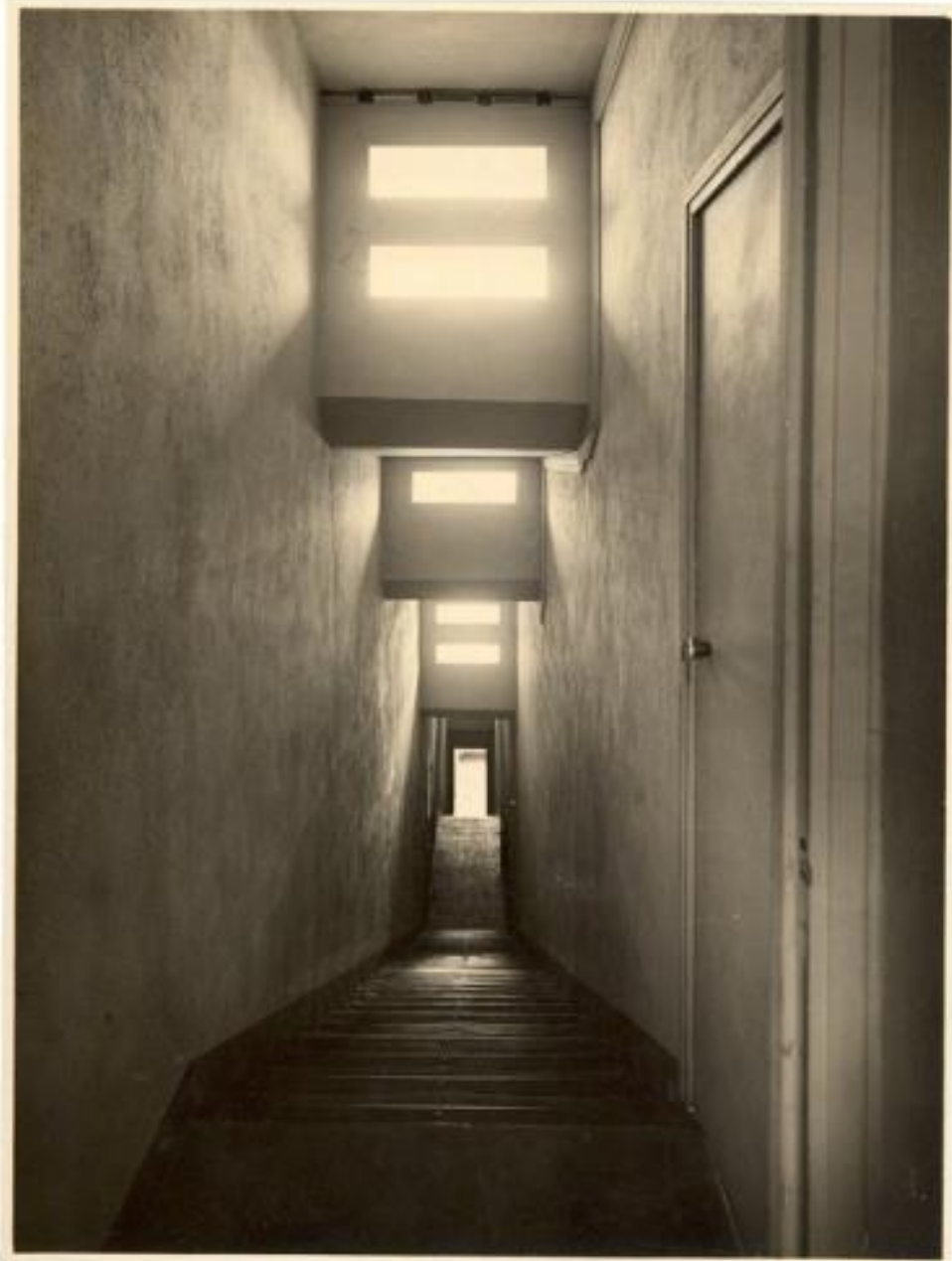

Figure 39: Bonney view to Sitting Rooms

Stair to Basement Sitting Rooms, Villa Noailles, Photo by Thérèse Bonney, 1928 


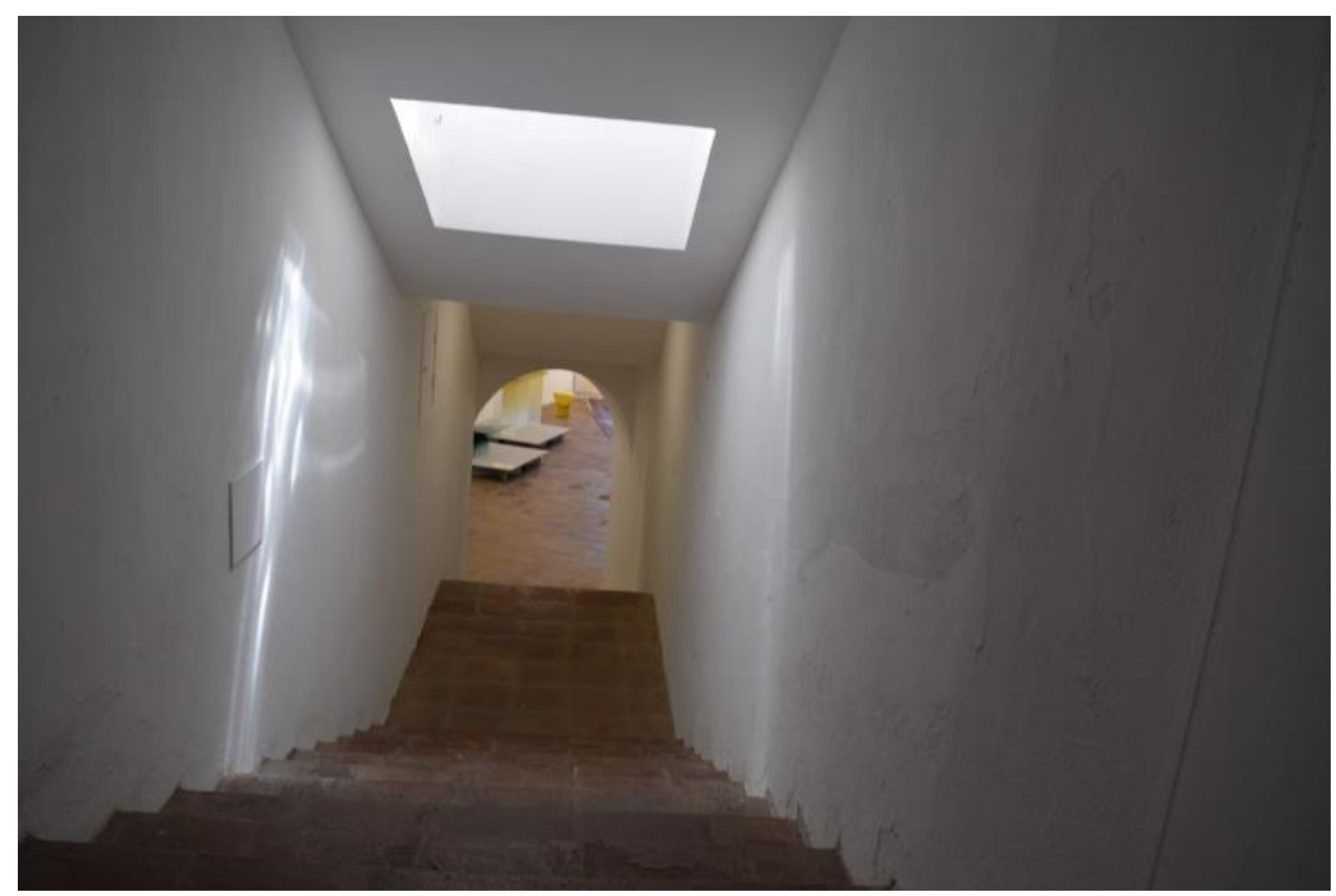

Figure 40: Author's image of stairs to Sitting Rooms

Author's unintentional iteration of above photo by Bonney, August 2016 


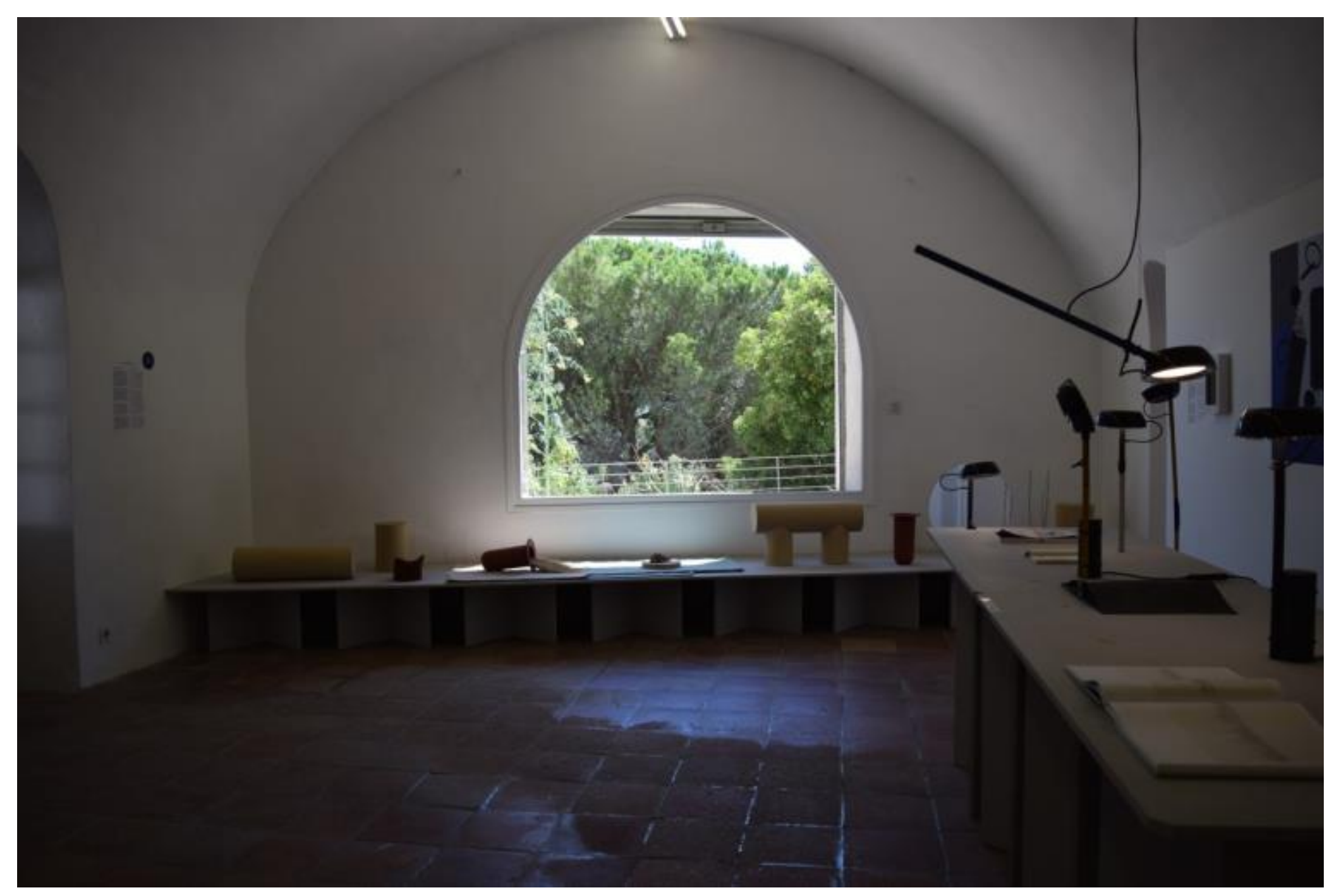

Figure 41: Sitting Rooms

Villa Noailles, Basement Sitting Room in remains of St. Bernard Cloister, now art exhibition space Photo: Author's Own, August 2016 


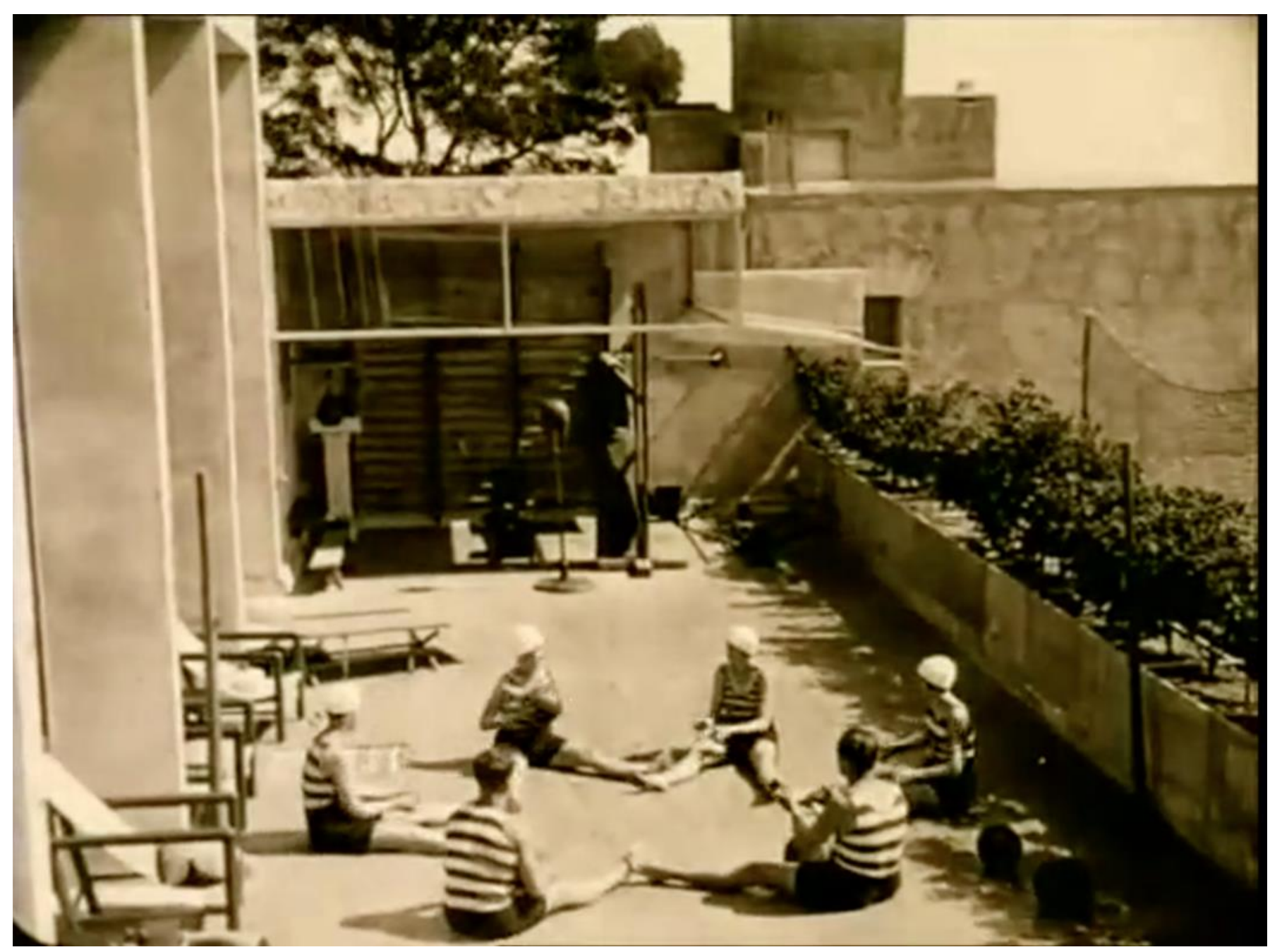

Figure 42: Biceps et Bijoux

Still taken from Biceps et Bijoux (1928) 

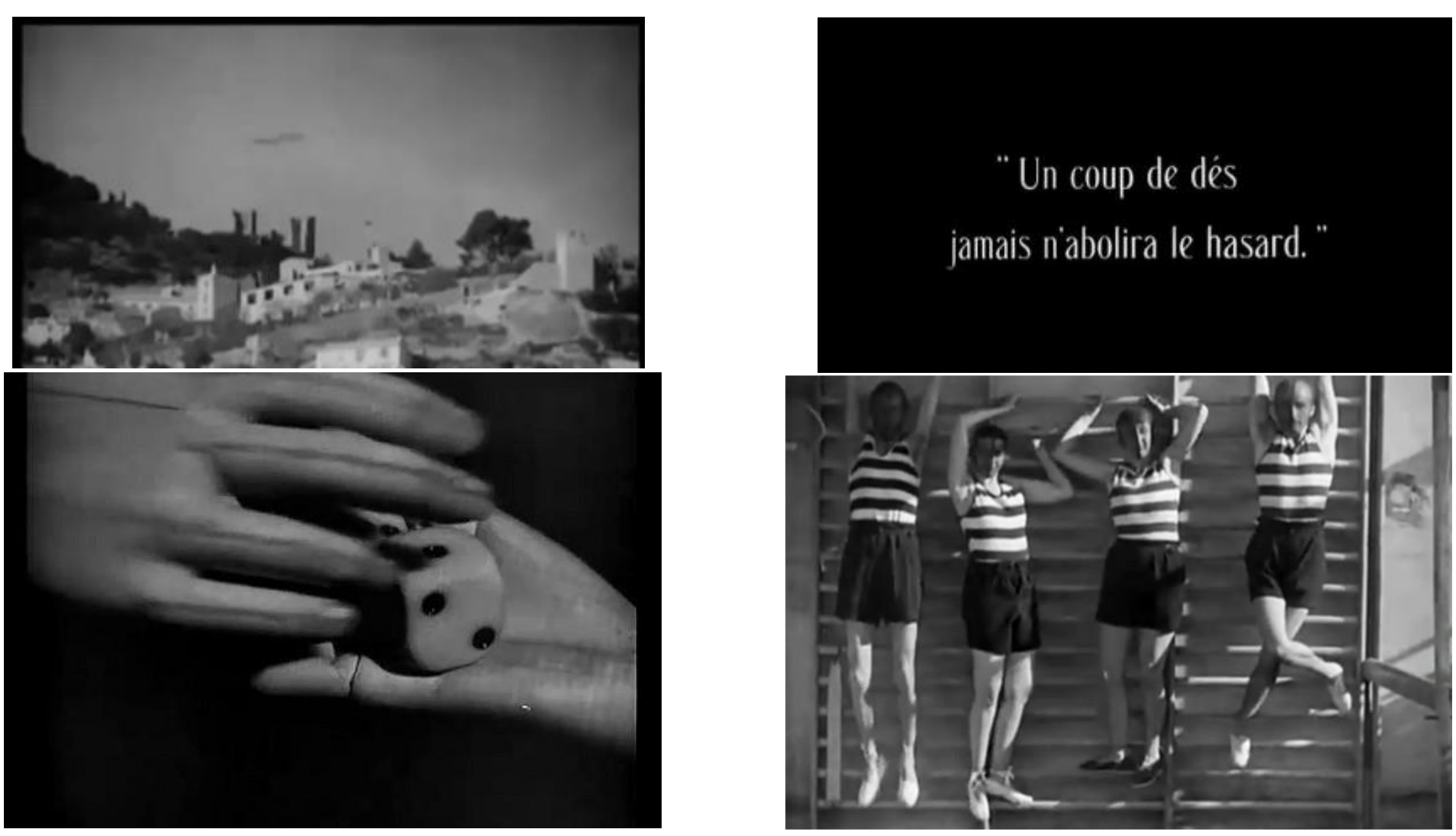

Stills, Les Mystères de Château du Dé, Man Ray, 1929

Upper Left: View of Villa Noailles, castle in the background

Upper Right and Bottom Left: Reference to Mallarmé's Un Coup de Dés

Bottom Right: Guests as actors

Figure 43: Stills from Les Mystères de Château du Dé 


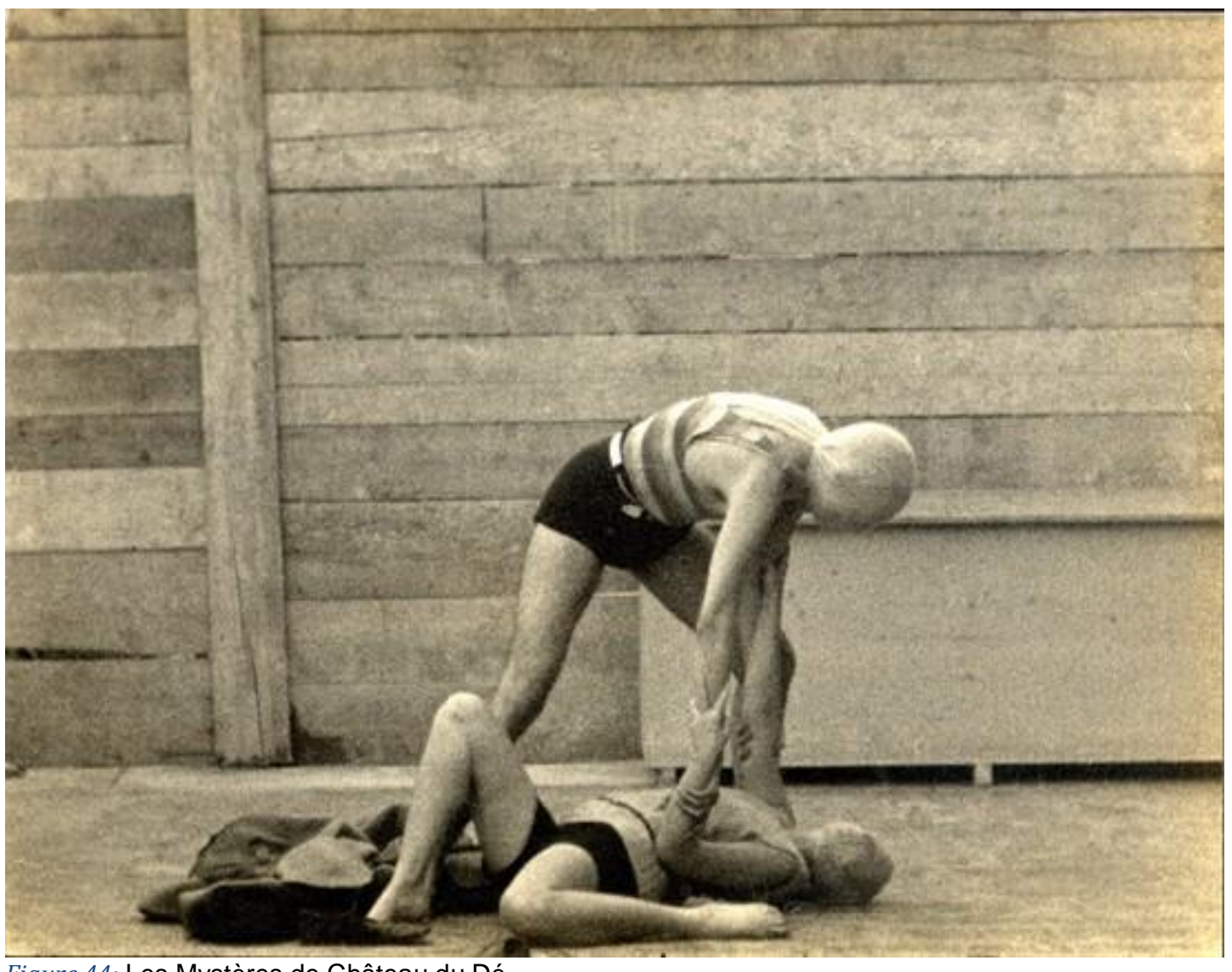

Figure 44: Les Mystères de Château du Dé

Still, Les Mystères de Château du Dé, Man Ray, 1929 


\section{Bibliography}

Barsacq, Léon. Le décor de film. [Paris: Seghers, 1970.

Becherer, Richard. "Monumentality and the Rue Mallet-Stevens." Society of Architectural Historians Journal 40, no. 1 (March 1981): 44-55.

. "Past Remembering: Robert Mallet-Stevens's Architecture of Duration." Assemblage, no. 31 (December 1996): 16-41.

Bruno, Giuliana. Atlas of Emotion: Journeys in Art, Architecture, and Film. Verso, 2002.

Butler, Judith. "Performative Acts and Gender Constitution: An Essay in Phenomenology and Feminist Theory." Theatre Journal 40, no. 4 (1988): 519-31. doi:10.2307/3207893.

Cavell, Stanley. The World Viewed: Reflections on the Ontology of Film. Cambridge: Harvard University Press, 1979.

Colomina, Beatriz. Privacy and Publicity: Modern Architecture as Mass Media /. Cambridge, Mass. : MIT Press, c1994. http://search.lib.virginia.edu/catalog/u2313409.

Colomina, Beatriz, and Jennifer Bloomer, eds. Sexuality \& Space. Princeton Papers on Architecture 1. New York, N.Y: Princeton Architectural Press, 1992. http://search.lib.virginia.edu/catalog/u1964473.

Constant, Caroline. "E. 1027 The Nonheroic Modernism of Eileen Gray.” Journal of the Society of Architectural Historians 53, no. 3 (1994): 265-79. doi:10.2307/990937.

Deshoulières, Dominique, and Hubert Jeanneau, eds. "Description by the Viscount de Noailles of the Construction of His Villa in Hyères - 1977." In Rob Mallet-Stevens: Architecte, 38788. Bruxelles: Archives d'Architecture Moderne, 1982. . "The Demands of Architecture." In Rob Mallet-Stevens: Architecte, 35-61. Bruxelles: Archives d'Architecture Moderne, 1982.

Dunworth, Shane Maree. "The de Noailles as Collectors and Patrons." Courtauld Institute of Art, 1985.

Friedman, Alice T. Women and the Making of the Modern House : A Social and Architectural History /. New York : Harry N. Abrams, 1998. http://search.lib.virginia.edu/catalog/u2795321.

Giedion, S. Space, Time and Architecture: The Growth of a New Tradition. Cambridge: Harvard University Press, 1947.

Gray, Eileen, Caroline Constant, and Wilfried Wang. Eileen Gray: An Architecture for All Senses. Berlin; Tübingen; Frankfurt am Main; Harvard: Wasmuth; Deutsches Architektur-Museum; Harvard University Press Graduate School of Design, 1996.

Higgott, Andrew, and Timothy Wray, eds. "Frank Yerbury and the Representation of the New." In Camera Constructs: Photography, Architecture and the Modern City, 23-33. Burlington: Ashgate Pub. Co, 2012. http://search.lib.virginia.edu/catalog/u5723275.

Hitchcock, Henry-Russell, and Philip Johnson. The International Style. New York: W.W. Norton, 1997.

Hornbeck, Elizabeth Jean. "Visions of Modernity: The Architectural Landscape of the 1925 Exposition of Decorative Arts, Paris." Ph.D., University of California, Santa Barbara, 2002. http://search.proquest.com/docview/304804620/abstract/E27CF79EDE824FB6PQ/1. Imbert, Dorothee. The Modernist Garden in France. New Haven: Yale University Press, 1993. Jeanneau, Hubert, ed. Rob Mallet-Stevens, Architecte /. Bruxelles : Archives d'architecture moderne, 1980. http://search.lib.virginia.edu/catalog/u208443. 
Knowles, Kim. "From Mallarmé to Mallet-Stevens: Reading Architectural Space in Man Ray's Les Mystères Du Château Du Dé." French Studies: A Quarterly Review 65, no. 4 (October 2011): 459-70.

Lawder, Standish D. The Cubist Cinema /. New York : New York University Press, 1975. http://search.lib.virginia.edu/catalog/u472051.

Loos, Adolf. "“L'Inhumain' Histoire Féerique (A Fairytale).” Translated by H. Goldman and Google Translator. Neue Freie Presse. July 29, 1924. http://anno.onb.ac.at/cgicontent/anno?aid=nfp\&datum $=19240729 \&$ zoom $=33$.

Mallet-Stevens, Robert. Robert Mallet-Stevens : L'œuvre Complète /. Paris : Centre Pompidou, 2005. http://search.lib.virginia.edu/catalog/u4296122.

—. Une Cité Moderne : Dessins de Rob Mallet-Stevens. Paris : Mille-Feuille, 1987. http://search.lib.virginia.edu/catalog/u1341411.

Manuel, Jacques. Biceps et Bijoux, 1928.

McLeod, Mary. "Perriand: Reflections on Feminism and Modern Architecture." Harvard Design Magazine No. 20, no. Stocktaking 2004: Nine Questions about the Present and Future of Design (2004). http://www.harvarddesignmagazine.org/issues/20/perriand-reflections-onfeminism-and-modern-architecture.

Melville, David. “Ebertfest: Roger Ebert's Film Festival: L’Inhumaine,” April 13, 2016. http://www.ebertfest.com/eighteen/linhumaine.html.

Meulemans, Megan1. "Exposing the Villa Noailles: The Women Behind the Promotion of Robert Mallet-Stevens." International Journal of the Image 1, no. 4 (December 2011): 119-39.

Neumann, Dietrich. Film Architecture: Set Designs from Metropolis to Blade Runner. Prestel, 1999.

Noailles, Charles, and Roy Lancaster. Mediterranean Plants and Gardens. Calverton: Floraprint Ltd., 1977.

Penz, François, and Maureen Thomas, eds. Cinema \& Architecture: Méliès, Mallet-Stevens, Multimedia. London: British Film Institute, 1997. http://search.lib.virginia.edu/catalog/u2638581.

Pinchon, Jean-François, ed. Rob. Mallet-Stevens: Architecture, Furniture, Interior Design: A Collective Work Presented by the Délégation À l'Action Artistique de La Ville de Paris on the Occasion of the Centenary of the Birth of Mallet-Stevens. 1st MIT Press ed. Cambridge, Mass: MIT Press, 1990. http://search.lib.virginia.edu/catalog/u1843269.

Plessix Gray, Francine du. "The Surrealists' Muse.” The New Yorker, no. September 24, 2007 (September 24, 2007). http://www.newyorker.com/magazine/2007/09/24/the-surrealistsmuse.

Ray, Man. The Mysteries of the Chateau de De. Documentary, Short, 1929.

Shanahan, Maureen G. 'Indeterminate and Inhuman: Georgette Leblanc in 'L'Inhumaine' (1924)." Cinema Journal 43, no. 4 (2004): 53-75.

Udovički-Selb, Danilo. "Reinventing Paris." Journal of the Society of Architectural Historians 74, no. 2 (June 1, 2015): 179-200. doi:10.1525/jsah.2015.74.2.179.

“Union Des Artistes Modernes - Oxford Reference.” Accessed April 29, 2017. http://www.oxfordreference.com/view/10.1093/oi/authority.20110803110717894.

L'Herbier, Marcel. L'Inhumaine (The Inhuman Woman). Lobster Films. Accessed April 30, 2017. http://virginia.kanopystreaming.com.proxy.its.virginia.edu/video/linhumaine. 